The Free Internet Journal

for Organic Chemistry
Review

Arkivoc 2018, part vi, 0-0

to be inserted by editorial office

\title{
4H-Pyrano[2,3-c]pyrazoles: a review
}

\author{
Noreen Aslam, ${ }^{* a}$ Jonathan M. White, ${ }^{b}$ Ansa M. Zafar, ${ }^{a}$ Mussarat Jabeen, ${ }^{a}$ Abdul Ghafoor, ${ }^{c}$ Naveed Sajjid, ${ }^{d}$ \\ Shazia Noreen, ${ }^{e}$ and Misbahul Ain Khan ${ }^{d}$
}

${ }^{a}$ Department of Chemistry, Government Sadiq College Women University, Bahawalpur, 63100, Pakistan

${ }^{b}$ School of Chemistry and Bio-21 Institute, University of Melbourne, VIC 3010, Australia

${ }^{c}$ Department of Chemistry, University of Central Punjab, Sahiwal, 57000, Pakistan

${ }^{d}$ Department of Chemistry, The Islamia University Bahawalpur, 63100, Pakistan

CB Girls Public High School \& College Bahawalpur, 63100, Pakistan

Email: noreenaslam7@gmail.com

\section{Abstract}

This review summarizes the synthetic pathways to pyrano[2,3-c]pyrazoles which either have a hydrogen atom, aryl substituent or condensed spiro group at the 4-position. Synthesis focuses on two component or MCR's including three, four and five components. Reaction conditions are variable including a green approach, nanoparticulate catalyst, microwave irradiation, ultrasonic irradiations and other catalysts. Most commonly used reagents are pyrazolones, benzylidenemalononitrile, hydrazines, $\beta$-ketoesters, malononitrile, aldehydes and ketones. Various substituted phenyl, naphthalene, anthracene, furan, thiophene, indole, tetrahydroquinoline have been incorporated at 4-position while amino and cyano groups at sixth and fifth position respectively and posses diverse biological properties.

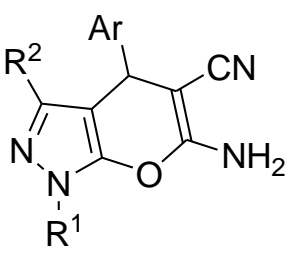

6-aminopyranopyrazole-5-cabonitriles

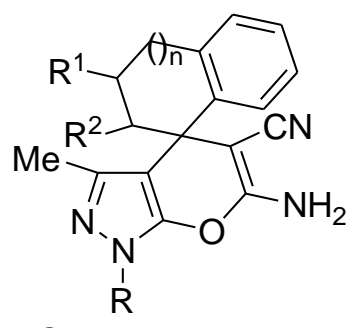

Spiropyranopyrazoles

Keywords: Pyrazolones, 6-aminopyranopyrazole-5-cabonitriles, synthesis, mechanism, biological activities 


\section{Table of Contents}

1. Introduction

2. Synthesis of Pyrano[2,3-c]pyrazoles

2.1. Two component syntheses

2.2. Three component syntheses

2.3. Four component syntheses

2.4. Five component syntheses

3. Biological Activities

4. Conclusions

\section{Introduction}

Pyranopyrazoles are an important class of heterocyclic ring systems, which can be prepared by a diverse range of synthetic procedures, ${ }^{1,2}$ have important pharmacological properties, ${ }^{1-3}$ been the topic of theoretical studies, ${ }^{4}$ and are of industrial significance. ${ }^{5,6}$ Out of four possible isomeric forms, pyrano[2,3-c]pyrazole (1), pyrano[4,3-c]pyrazole (2), pyrano[3,2-c]pyrazole (3) and pyrano[3,4-c]pyrazole (4), isomer $\mathbf{1}$ is the most widely studied. ${ }^{1}$ The synthesis, derivatization and biological activities of a range of derivatives of $\mathbf{1}$ have been reported (Figure 1). ${ }^{1,2}$
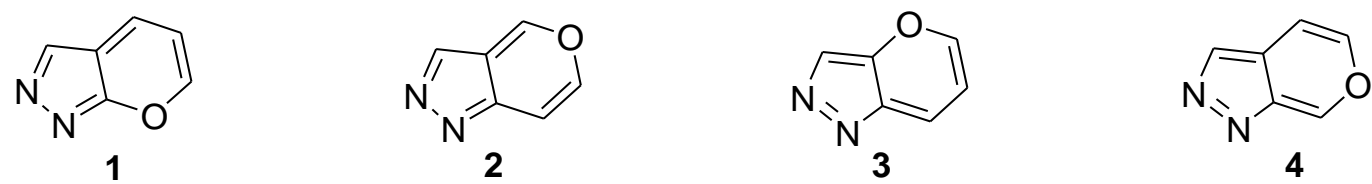

Figure 1. Structures of isomeric pyranopyrazoles.

The first synthesis of pyrano[2,3-c]pyrazoles (1) was reported by Stollé, who prepared it from hydrazine and ethyl acetoacetate. ${ }^{7}$ Wolff also reported its synthesis at about the same time. ${ }^{8}$ In 1973 , Junek and Aigner synthesized some polynitrile derivatives of pyrano[2,3-c]pyrazoles which initiated developments in functionalized pyranopyrazoles synthesis such as pyrano[2,3-c]pyrazol-6-one (5), pyrano[2,3-c]pyrazol-4-one (6) and $4 \mathrm{H}$-pyrano[2,3-c]pyrazole (7) (Figure 2). ${ }^{9}$ Khan and co-workers also synthesized various derivatives of 5 and $6 .^{10,11}$
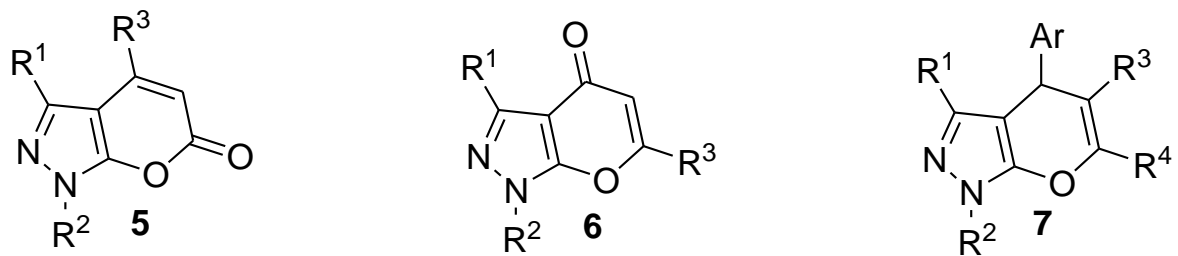

Figure 2. Derivatives of pyranopyrazoles. 
This review focuses on the developments in the chemistry of derivatives of $\mathbf{7}$, especially their synthesis and leaving the treatment of pyranopyrazolones outside the scope of the present review. Pyranopyrazole 7 shows various biological activities such as Chk1 inhibitors, acetylcholinesterase (AChE) inhibitors (Figure 3 ). ${ }^{1,3}$<smiles>Cc1n[nH]c2c1C(c1ccc(O)c(O)c1)C(C#N)=C(N)O2</smiles>

Chk1 inhibitors

8<smiles></smiles>

(AChE) inhibitors

\section{Figure 3}

Emphasis has been given to the various methods published in the literature, to synthesize a number of 4-arylpyranopyrazoles or 4-spiropyranopyrazoles using different reactants with/without catalyst in solvents (organic/ionic/water) or without solvent at various temperatures under changing reaction conditions together with the reported mechanism. Methods are represented based on the number of components condensed together to generate the resultant compounds. This review does not include all publications in this area, but what we consider to represent seminal articles related to the topic. To the best of our knowledge, it is the first attempt to summarize the synthetic methods of 4-spiropyrano[2,3-c]pyrazoles, as the other reviews ${ }^{1,2}$ also includes derivatives $\mathbf{5}$ and $\mathbf{6}$ as well as their reactions.

\section{Synthesis of Pyrano[2,3-c]pyrazoles (7)}

\subsection{Two component syntheses}

Junek and Aigner treated tetracyanoethylene with pyrazol-5-one and 5-aminopyrazole to obtain pyrano[2,3c]pyrazoles (10), pyrazolo[3,4-b]pyridines (11) and dipyrazolyl malonodinitriles (12) respectively depending on reaction condition (Figure 4). ${ }^{9} \quad$ 6-Amino-1,3-disubstituted-4,4-5-tricyanopyrano[2,3-c]pyrazole (10) was obtained by refluxing the appropriate pyrazolone and tetracyanoethylene in ethanol.

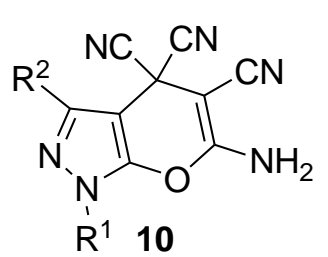

yield $72 \%$

$\mathrm{R}^{1}=\mathrm{H}, \mathrm{Ph}$

$\mathrm{R}^{2}=\mathrm{Ph}, \mathrm{CO}_{2} \mathrm{Et}$

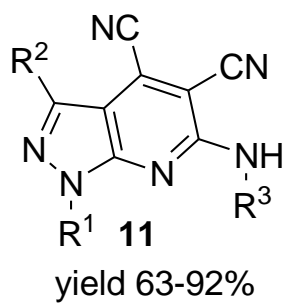

$\mathrm{R}^{1}=\mathrm{Ph}, \mathrm{CHMe}_{2}$

$\mathrm{R}^{2}=\mathrm{H}, \mathrm{Me}$

$\mathrm{R}^{3}=\mathrm{H}$, COMe

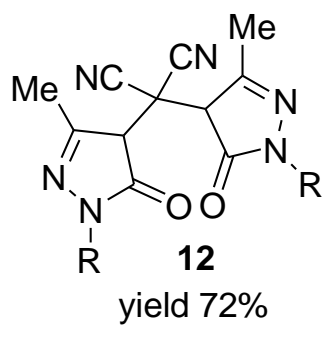

$\mathrm{R}=\mathrm{Ph}, 4-\mathrm{Me}-\mathrm{Ph}$

\section{Figure 4}


Otto refluxed 4-benzylide-pyrazol-5-one (13) with malononitrile (14) in methanol in the presence of sodium acetate catalyst to obtain pyrano[2,3-c]pyrazole (15) ${ }^{12}$ (Scheme 1 ).

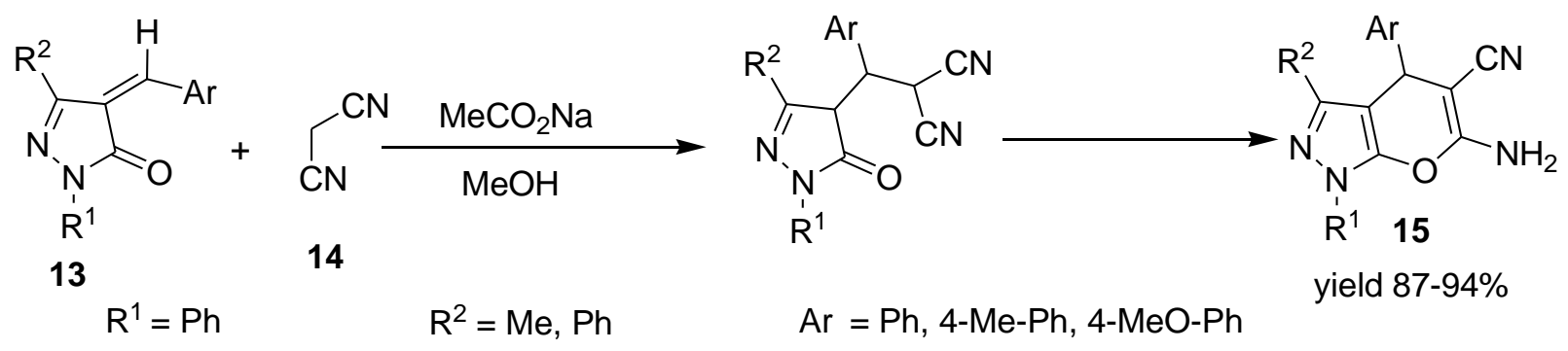

\section{Scheme 1}

Wang et al. developed an efficient synthesis of 6-hydroxy-6-trifluoromethyl-pyrano[2,3-c]pyrazoles (18) in excellent yields (85-99\%) using 10 mol\% of 1,4-diazobicyclo[2.2.2]octane (DABCO) as base in DCM solvent at room temperature. ${ }^{13}$ Other bases such as triethylamine, 1,8-diazabicyclo[5.4.0]undec-7-ene (DBU), 4dimethylaminopyridine (DMAP), $\mathrm{N}$-N-dimethylaniline $\left(\mathrm{C}_{6} \mathrm{H}_{5} \mathrm{NMe}_{2}\right)$ were also tested in different solvents. All bases showed good results, but $20 \mathrm{~mol} \%$ of DABCO was found to be an excellent catalyst to provide diastereoselective control in the formation of pyranopyrazoles (6:1-30:1). X-Ray crystallographic analysis of the major isomer indicated that the trans-products were predominantly formed (Scheme 2).

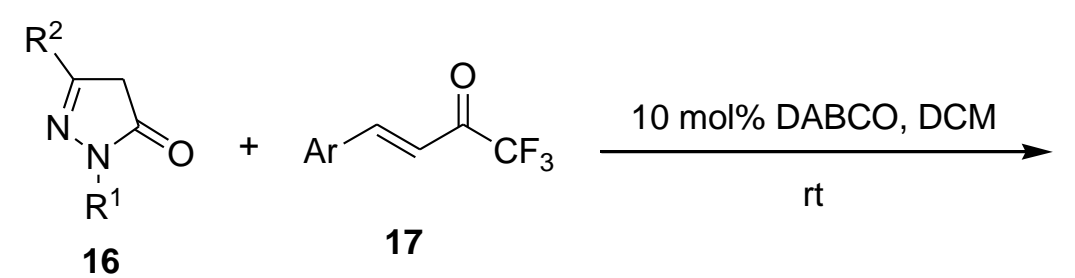

$\mathrm{R}^{1}=\mathrm{Ph}, \mathrm{Me}, 4-\mathrm{Br}-\mathrm{Ph}, \mathrm{CH}_{2}-\mathrm{Ph}$

$\mathrm{R}^{2}=\mathrm{Me}, \mathrm{CF}_{3}, \mathrm{Ph}, 4-\mathrm{Br}-\mathrm{Ph}, 4-\mathrm{MeO}-\mathrm{Ph}$<smiles>[R]c1nn([R18])c2c1[C@@H](Br)C[C@@](O)(C(F)(F)F)O2</smiles>

yield $85-99 \%$ $\mathrm{Ar}=\mathrm{Ph}$, 2-Me-Ph, 3-Me-Ph, 4-Me-Ph, 4-MeO-Ph, 4-Cl-Ph, 3,5-dimethyl-Ph, 4-Br-Ph, 4-CF $-\mathrm{Ph}, 3,4,5$-trifluoro-Ph, 4$\mathrm{Ph}-\mathrm{Ph}, 9$-anthracenyl, 2-naphthalenyl, 2-thienyl

\section{Scheme 2}

The reaction route is believed to involve tandem Michael addition of pyrazolone 16 to the $\alpha, \beta$ trifluoromethyl ketones (17), followed by aromatization and cyclization (Scheme 3). ${ }^{13}$ 


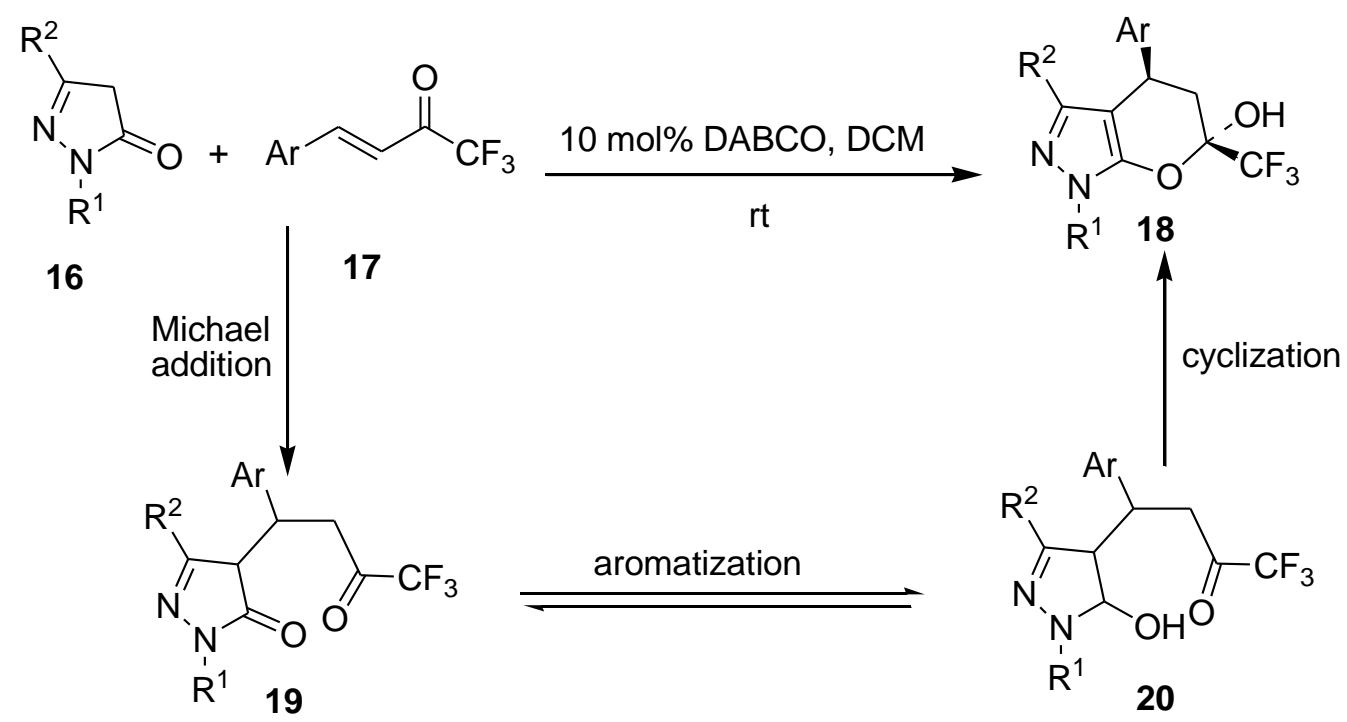

$\mathrm{R}^{1}=\mathrm{Ph}, \mathrm{Me}, 4-\mathrm{Br}-\mathrm{Ph}, \mathrm{CH}_{2}-\mathrm{Ph}$

$\mathrm{R}^{2}=\mathrm{Me}, \mathrm{CF}_{3}, \mathrm{Ph}, 4-\mathrm{Br}-\mathrm{Ph}, 4-\mathrm{MeO}-\mathrm{Ph}$

$\mathrm{Ar}=\mathrm{Ph}$, 2-Me-Ph, 3-Me-Ph, 4-Me-Ph, 4-MeO-Ph, 4-Cl-Ph, 3,5-dimethyl-Ph, 4-Br-Ph, 4- $\mathrm{CF}_{3}$ - $\mathrm{Ph}, 3,4,5$-trifluoro-Ph, 4$\mathrm{Ph}$-Ph, 9-anthracenyl, 2-naphthalenyl, 2-thienyl

\section{Scheme 3}

Tetrahydroquinoline derivatives are well known for antibiotic, antitumor, anti-allergic, antidepressant, anti-ulcer, anticonvulsant, anti-fertility, antioxidant and herbicidal applications. ${ }^{14}$ Hence, Pandit and Lee synthesized tetrahydroquinolines bearing pyranopyrazoles 21-23 in acetonitrile containing 10 mol\% of EDDA at $60{ }^{\circ} \mathrm{C}$ for $1-2 \mathrm{~h}$ (Figure 5). ${ }^{15}$ The cis-stereochemistry of the product was confirmed by X-ray crystallography and rationalized by the mechanism outlined in Scheme 4.<smiles></smiles>

21

yield $80-92 \%$

$\mathrm{R}^{1}=\mathrm{Me}, \mathrm{Ph}$

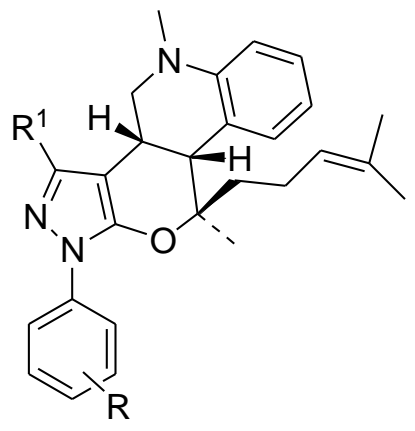

22

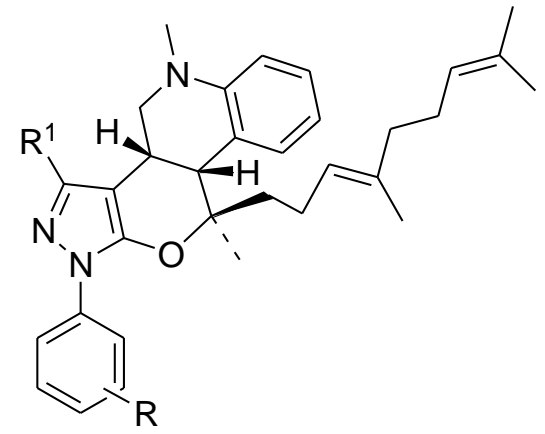

23 yield $68-88 \%$ yield $60-77 \%$ $\mathrm{R}=\mathrm{H}, 2-\mathrm{Cl}, 4-\mathrm{Cl}, 4-\mathrm{NO}_{2}$, 2,5-dichloro, 4-Me

\section{Figure 5}




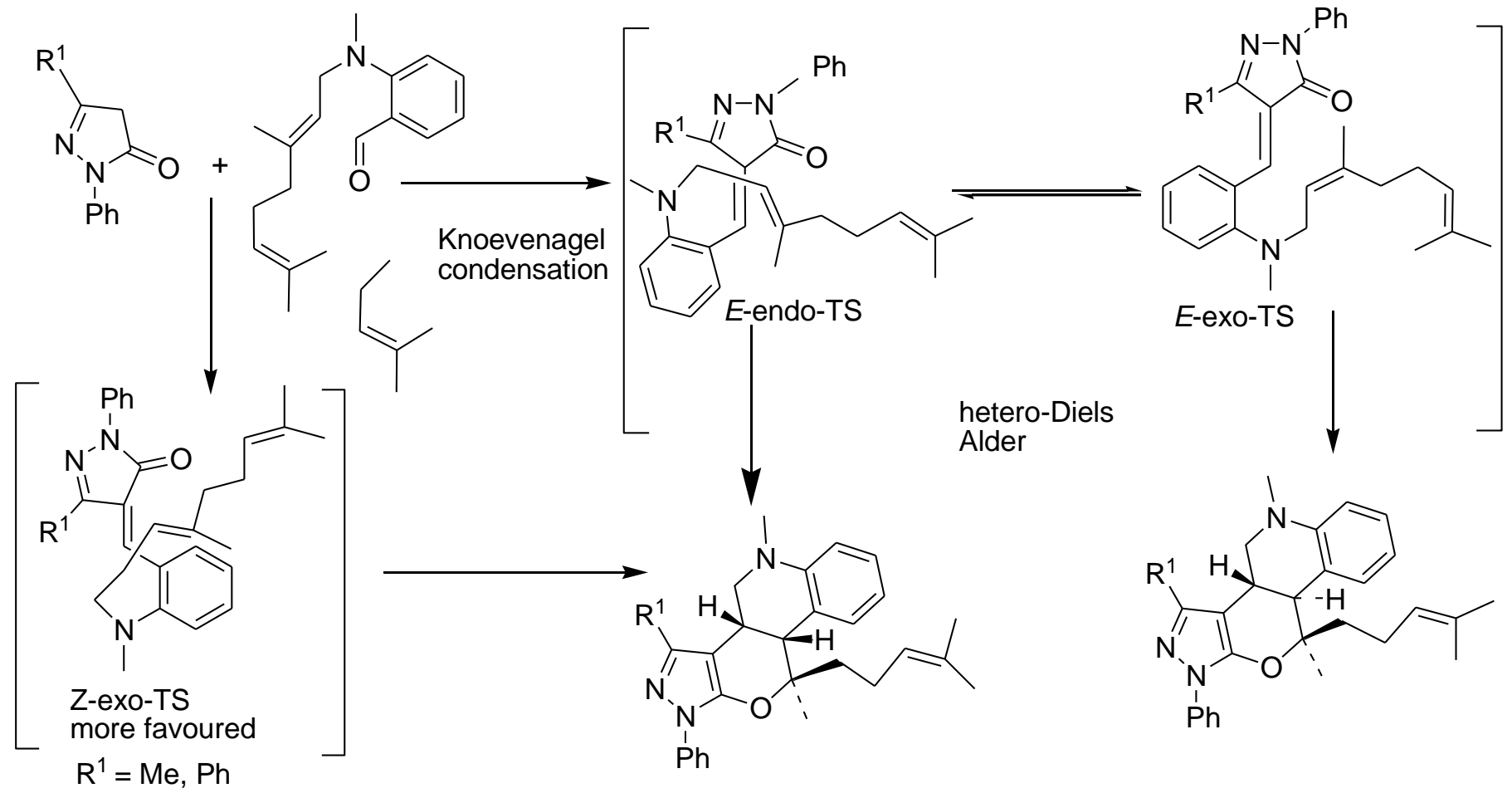

Scheme 4. Mechanism.

In the literature, various derivatives of $\mathbf{2 4}$ were reacted with malononitrile (14) in benzene as solvent containing triethylamine giving pyranopyrazoles 25, which were screened for fungicidal, herbicidal and insecticidal activities. ${ }^{16}$ All compounds were inactive fungicidal and insecticidal agents however, one compound was active herbicidal agent (Scheme 5).

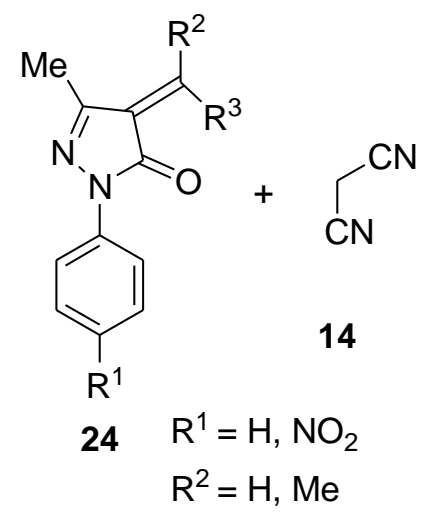

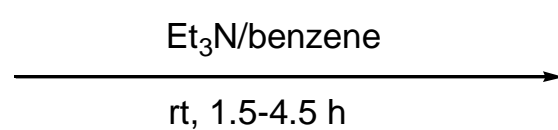

$\mathrm{R}^{3}=\mathrm{Me}, \mathrm{Ph}, 4-\mathrm{Cl}-\mathrm{Ph}, 4-\mathrm{Me}-\mathrm{Ph}$, 4-NO $-\mathrm{Ph}, 3,4-$ dichloro-Ph<smiles>[R7]c1ccc(-n2nc(C)c3c2OC(N)=C(C#N)C3([R])[R])cc1</smiles>

25

yield $58-98 \%$

\section{Scheme 5}

Gogoi and Zhao carried out enantioselective synthesis by reacting pyrazol-5-one 16 and benzylidenemalononitrile (26) under catalytic action of different cinchona alkaloids including quinine, cupreine, 9-epi-cupreine and 9-epi-amino-9-deoxyquinine in various solvents $\left(\mathrm{CH}_{2} \mathrm{Cl}_{2}, \mathrm{CHCl}_{3}\right.$, THF, ether, benzene, MeCN). ${ }^{17}$ Cupreine gave excellent selectivities in dichloromethane and the enantioselectivity found to be highly dependent on the reaction conditions, structure of the catalysts and the substrates hence, enantioselectivity $\left(e e^{c}\right)$ decreased with small changes in catalyst, solvent and with presence of substituent on 
the phenyl ring of the benzylidenemalononitrile (Scheme $6 \mathrm{~A}$ ). The structure was confirmed by X-ray studies. Ahmad and co-workers subjected an ethanolic solution of pyrazolone 16 and benzylidemalononitrile (26) containing piperidine to microwave irradiation for two min to get pyranopyrazoles, which were subjected to various derivatization reactions. ${ }^{5}$ The synthesized compounds were found to be effective anti-oxidants for lubricating oil (Scheme 6 B). Similarly, Elziaty and co-workers refluxed ethanolic solutions of both reactants in the presence of piperidine for $1 \mathrm{~h}$ to get pyranopyrazoles which treated with various reagents (formic acid, acetamide, acetic anhydride, aldehydes e.t.c) to form important condensed heterocyclic moieties ${ }^{18}$ (Scheme 6 C).

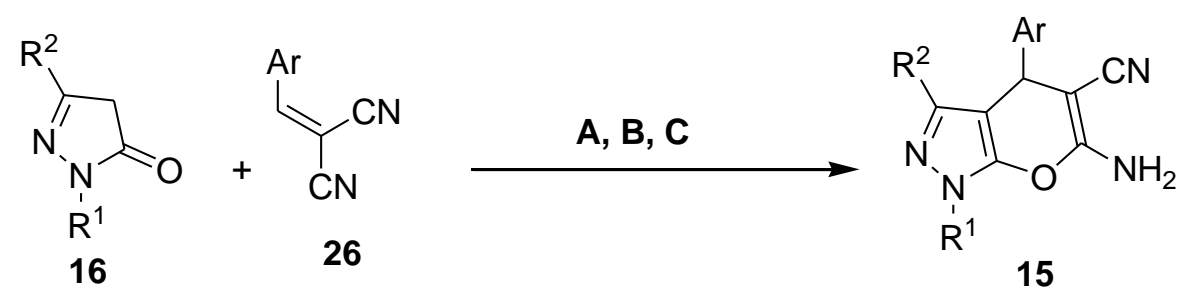

\begin{tabular}{|c|c|c|c|c|c|}
\hline Scheme & $\mathbf{R}^{\mathbf{1}}$ & $\mathbf{R}^{\mathbf{2}}$ & \multicolumn{1}{|c|}{ Ar } & Conditions & Yield \\
\hline A & $\mathrm{H}$ & $\mathrm{Me}, \mathrm{Et}, \mathrm{Ph}$ & $\begin{array}{l}\mathrm{Ph}, 4-\mathrm{Me}-\mathrm{Ph}, 4-\mathrm{MeO}-\mathrm{Ph}, 4-\mathrm{Cl}- \\
\mathrm{Ph}, 4-\mathrm{Br}-\mathrm{Ph}, 4-\mathrm{I}-\mathrm{Ph}, 4-\mathrm{F}-\mathrm{Ph}, 4- \\
\mathrm{CN}-\mathrm{Ph}, 4-\mathrm{NO}_{2}-\mathrm{Ph}, 3-\mathrm{Br}-\mathrm{Ph}\end{array}$ & $\begin{array}{l}\mathrm{CH}_{2} \mathrm{Cl}_{2}, \mathrm{rt}, \\
\text { cupreine 5 mol\% }\end{array}$ & $79-96 \%$ \\
\hline B & $\mathrm{Ph}$ & $\mathrm{Me}$ & $4-\mathrm{HO}-\mathrm{Ph}$ & $\begin{array}{l}\text { EtOH, piperidine, } \\
\mathrm{MW} 160 \mathrm{~W}, 2 \mathrm{~min}\end{array}$ & $51-83 \%$ \\
\hline C & $\mathrm{H}$ & $\mathrm{Me}$ & $4-\mathrm{Cl}-\mathrm{Ph}$ & $\begin{array}{l}\text { EtOH, piperidine, } \\
\text { reflux 1 h }\end{array}$ & $85 \%$ \\
\hline
\end{tabular}

\section{Scheme 6}

Water as a green solvent, is the most environmentally friendly, safe and inexpensive choice to decrease pollution, toxicity and cost of a reaction. ${ }^{19}$ Peng and co-workers used pure aqueous media for reaction of 5 alkoxycarbonyl-2-amino-4-aryl-3-cyano-6-methyl-4H-pyrans (27) and hydrazine hydrate in the presence of a catalytic quantity of piperazine by three methods (i) heating (ii) exposing to microwave irradiation (iii) exposing to a combination of microwave and ultrasound irradiation where, the latter was found to be excellent in terms of yield within short time ${ }^{20}$. It was assumed that powerful ultrasound irradiation causes cavitations and high-velocity interparticle collisions, which cleaned the surface, thus mass transfer between two phases increased and the reaction completed fast without need of any organic co-solvent (Scheme 7).

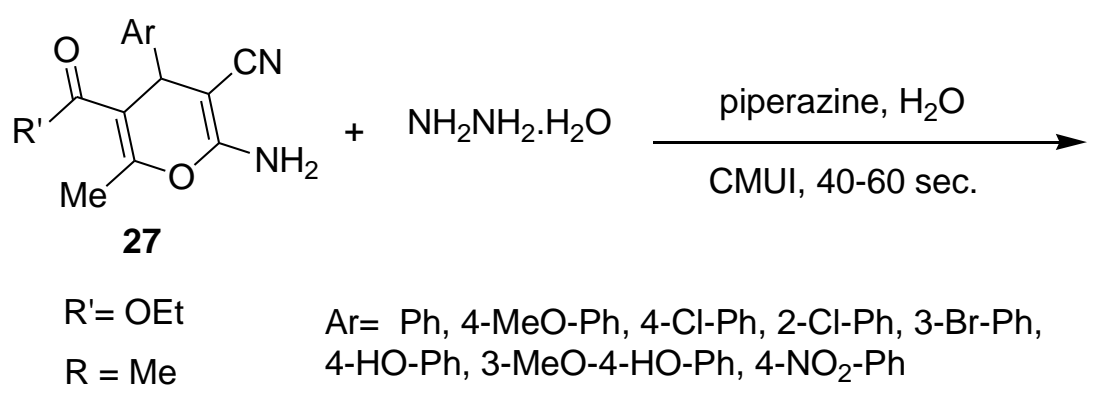

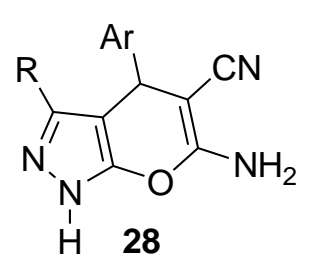

yield $89-93 \%$

\section{Scheme 7}


Trichili and co-workers allowed a solution of substituted hydroxybenzaldehyde/naphthaldehyde $\mathbf{2 9}$ and malononitrile in ethanol containing piperidine to stir to get 3-cyanoiminocoumarins (30). These were reacted with thiosemicarbazide at room temperature in chloroform to form benzopyrano[2,3-c]pyrazoles (31), or derivatized to 3-cyano- $N$-ethoxycarbonyliminocoumarin (32) which was further refluxed with 4phenylsemicarbazide or thiosemicarbazide to form 3-triazolonyliminocoumarins $(33)^{21}$ (Scheme 8). The proposed mechanism of reaction is given (Scheme 9).

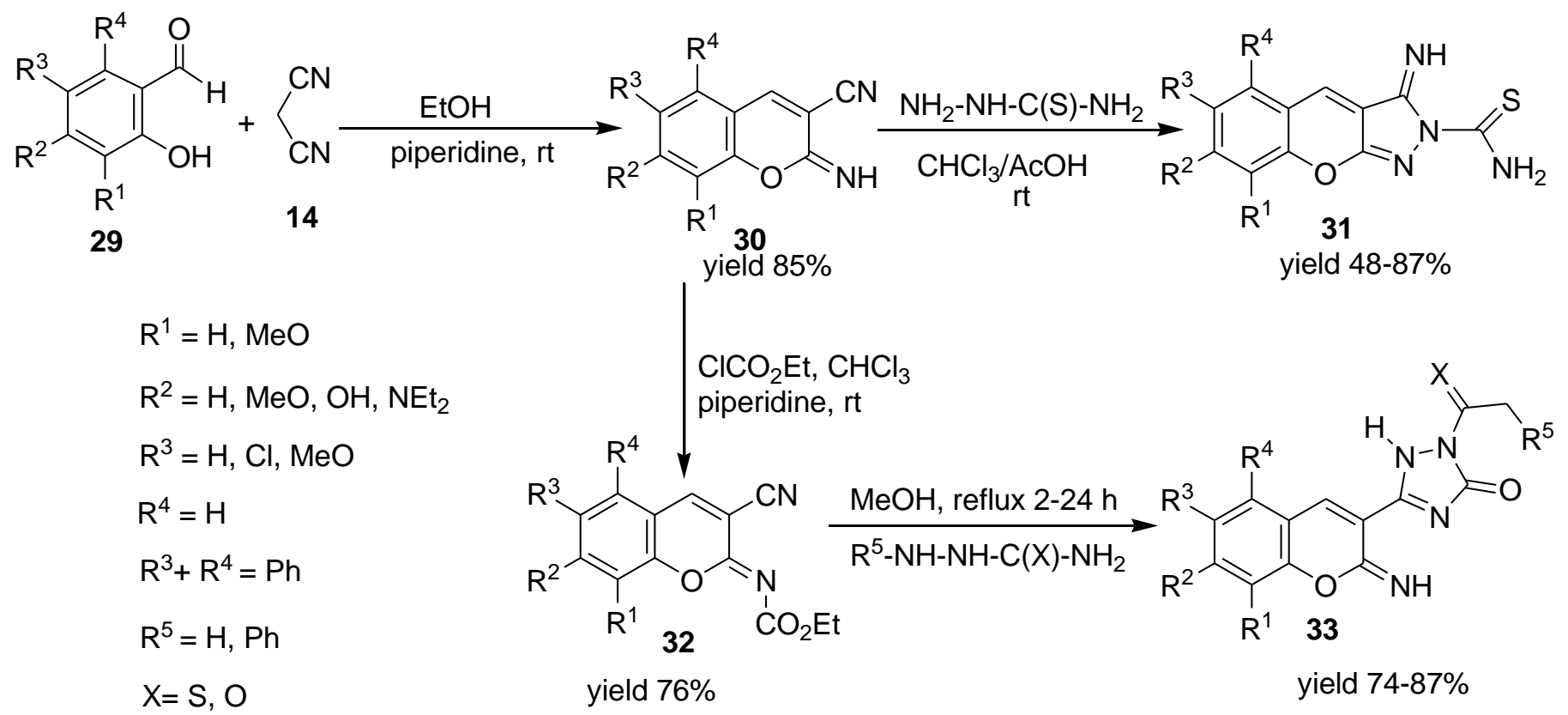

\section{Scheme 8}

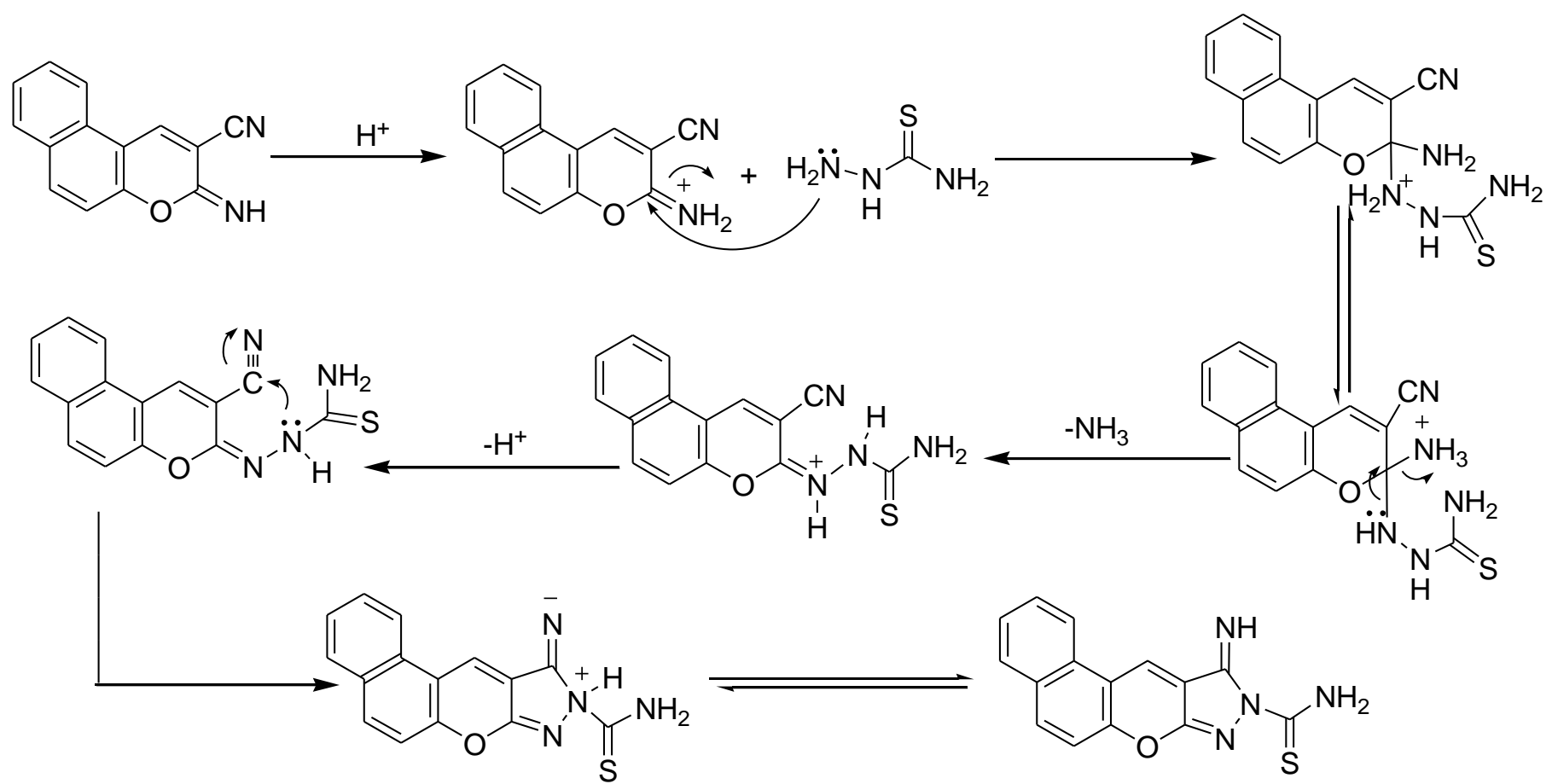

Scheme 9. Mechanism. 
Shestopalov and co-workers treated 3-(methyl, phenyl, t-butyl, methoxymethylene, trifluoromethyl)substituted-5-pyrazolones $\mathbf{3 4}$ with heterocyclic or polyalkylated benzylidemalononitrile (26) to get 4-arylpyranopyrazoles $\mathbf{3 5}$ in good to excellent yields. ${ }^{22}$ Reaction was found to be successful for sterically hindered aldehydes as well as to electron-withdrawing and electron-donating substituents at the 3-position of the pyrazoles. X-Ray crystallography studies showed that these pyranopyrazoles exist in the $2-H$ tautomeric form rather than as $1-H$ (Scheme 10).

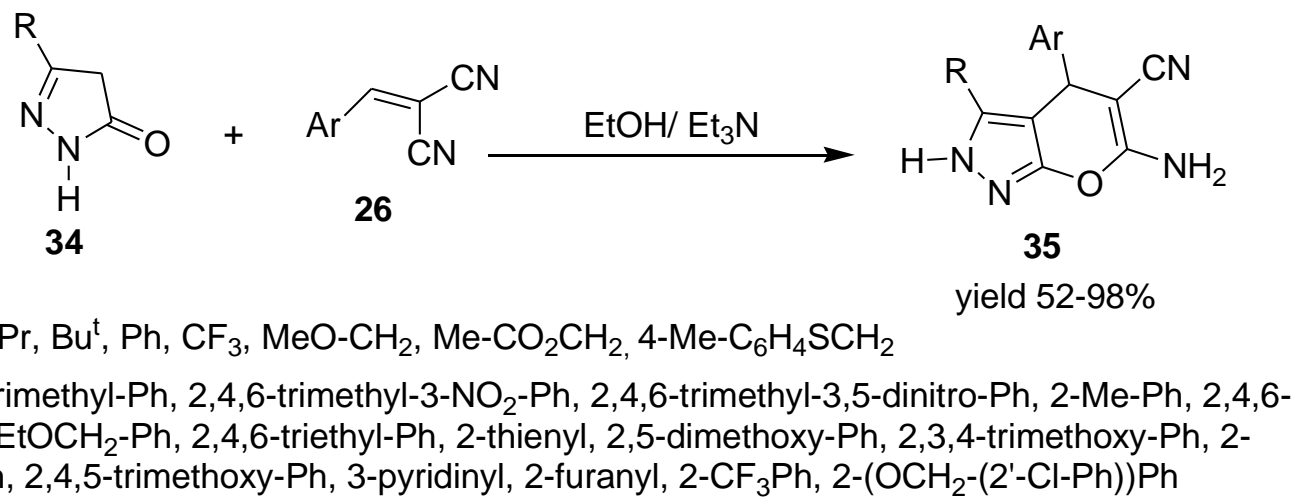

\section{Scheme 10}

Ismail and co-workers refluxed 2-(2-(3-methyl-5-oxo-4,5-dihydropyrazol-1-yl)-2-oxoethoxy)benzamide (36) and benzylidemalononitrile (26) in absolute ethanol containing piperidine to produce benzamide based pyranopyrazoles 37 (Scheme 11), which were subjected to further derivatization and subsequently screened for their anti-inflammatory and ulcerogenic activities. ${ }^{23}$ All compounds were found to be active but, one bearing 2,5-dimethoxphenyl group at the 4-position showed excellent results compare to the other analogues which suggested that the presence of electron-donating group is favorable for anti-inflammatory activity.<smiles>CC1=NN(C(=O)COc2ccccc2C(N)=O)C(=O)C1</smiles>

36<smiles>N#CC(C#N)=CBr</smiles>

26

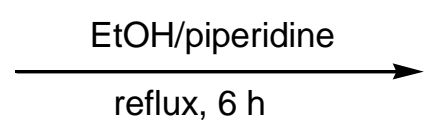

$\mathrm{Ar}=4-\mathrm{Cl}-\mathrm{Ph}, 4-\mathrm{Br}-\mathrm{Ph}, 2,5-$ dimethoxy- $\mathrm{Ph}, 2-\mathrm{Br}-\mathrm{Ph}$

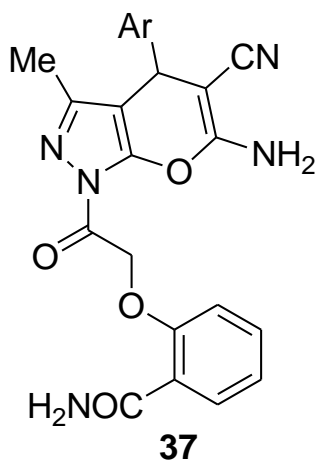

yield $51-62 \%$

\section{Scheme 11}

Similarly, Saundane and co-workers refluxed 3-methyl-1-(5'-substituted-3'-phenyl-1H-indol-2'-carbonyl)-5$(4 \mathrm{H})$ pyrazolones (38) with benzylidemalononitrile (26) in ethanol containing triethylamine to provide indole based pyranopyrazoles 39 (Scheme 12) and subjected these to further derivatization. ${ }^{24}$ All compounds were tested for biological activities and found to be active antibacterial and antifungal agents and exhibited good scavenging activity. 
<smiles>[R]c1ccc2[nH]c(C(=O)N3N=C(C)CC3=O)c(-c3ccccc3)c2c1</smiles>

38<smiles>[13CH3]C=C(C#N)C#N</smiles>

$\mathrm{Ar}=\mathrm{Ph}, 4-\mathrm{Cl}-\mathrm{Ph}, 4-\mathrm{NO}_{2}-\mathrm{Ph}, 4-\mathrm{MeO}-\mathrm{Ph}, 6-\mathrm{MeO}-$ naphthyl

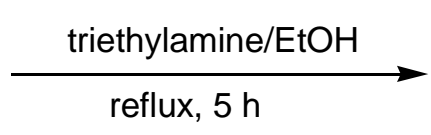

reflux, $5 \mathrm{~h}$

$\mathrm{R}=\mathrm{Cl}, \mathrm{Me}, \mathrm{OMe}$

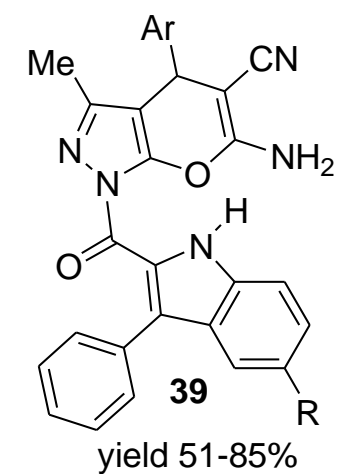

\section{Scheme 12}

Dyachenko and Rusanov allowed to stir benzylidepyrazolone (40) with cyanothioacetamide (41) or malononitrile (14) in morpholine containing an ethanolic solution to obtain various pyranopyrazoles 44 . $^{25}$ The $^{2}$ reaction mechanism was proposed to involve the Michael adduct 42-43, which cyclized with concomitant removal of hydrogen sulphide in case of cyanothioacetamide (Scheme 13). An X-ray study of 6-amino-5-cyano4-isopropyl[hexyl)-3-phenyl-2H,4H-pyrano[2,3-c]pyrazoles showed its $2 \mathrm{H}, 4 \mathrm{H}$-isomeric form rather than previously reported $1 \mathrm{H}, 4 \mathrm{H}$-isomeric form was adopted in the solid state.

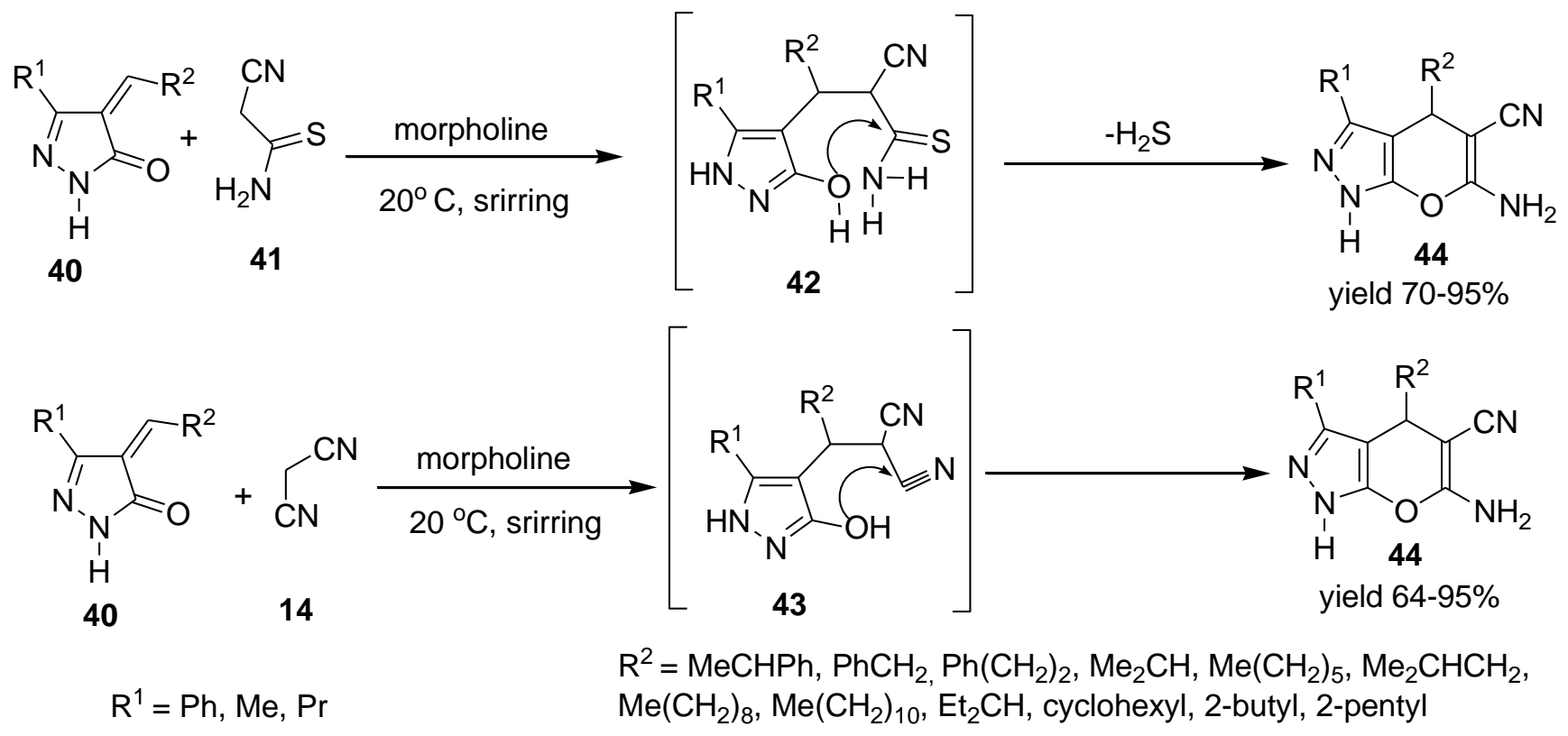

\section{Scheme 13}

Hafez and co-workers reacted 2-oxo-3-substituted indole (45) with pyrazolone 16 or 2ethoxycarbonylmethyl-2-thiazolin-5-one (46) in boiling ethanol to prepare spiropyranylindolone (47) and ethyl-2-(4-hydroxythiazol-2-yl)-2-(2-oxoindolin-3-ylidene)acetate (48) derivatives respectively (Scheme 14). ${ }^{26}$ 
<smiles>CCOC(=O)/C(=C1/C(=O)N(CO)c2ccccc21)c1nc(O)cs1</smiles>

48

yield $62 \%$

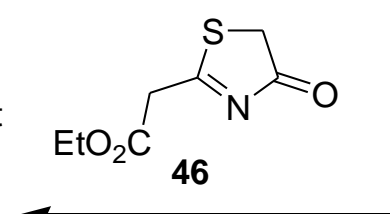

EtOH, reflux $2 \mathrm{~h}$

$\mathrm{R}^{1}=\mathrm{H}, \mathrm{Ph} \quad \mathrm{R}^{2}=\mathrm{Me}$<smiles>[X]C(C#N)=C1C(=O)Nc2ccccc21</smiles>

45

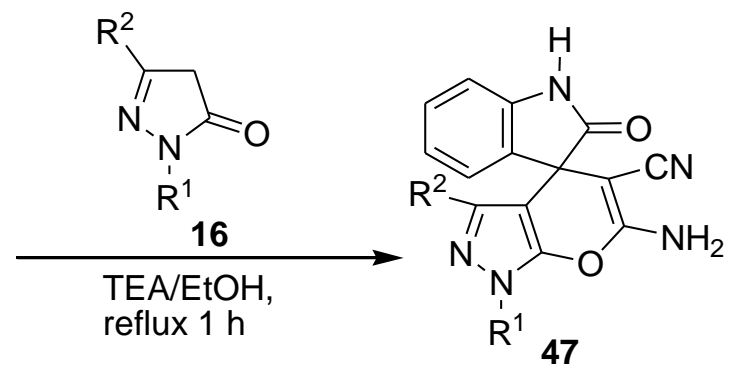

$\mathrm{X}=\mathrm{CN}, \mathrm{CO}_{2} \mathrm{Et}$

\section{Scheme 14}

In another scheme of reaction, indole-2,3-dione (49) was derivatized with malonic acid, thionyl chloride and various arenes to produce intermediate $\mathbf{5 0}$ (Scheme 15), which on refluxing with pyrazolone $\mathbf{1 6}$ in pyridine formed intermediate $\mathbf{5 1}$ which cyclized using different reagents such as phosphorus pentoxide, ammonium acetate and acetonitrile at reflux temperature to afford spiro[indoline-3,4'-(pyrazolo[4,5-b]pyran)]-2-ones (52) (Scheme 16). ${ }^{27}$

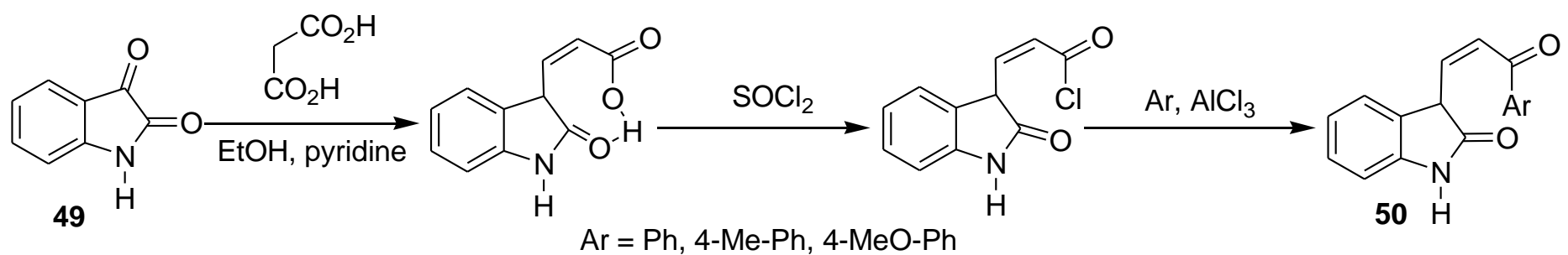

\section{Scheme 15}

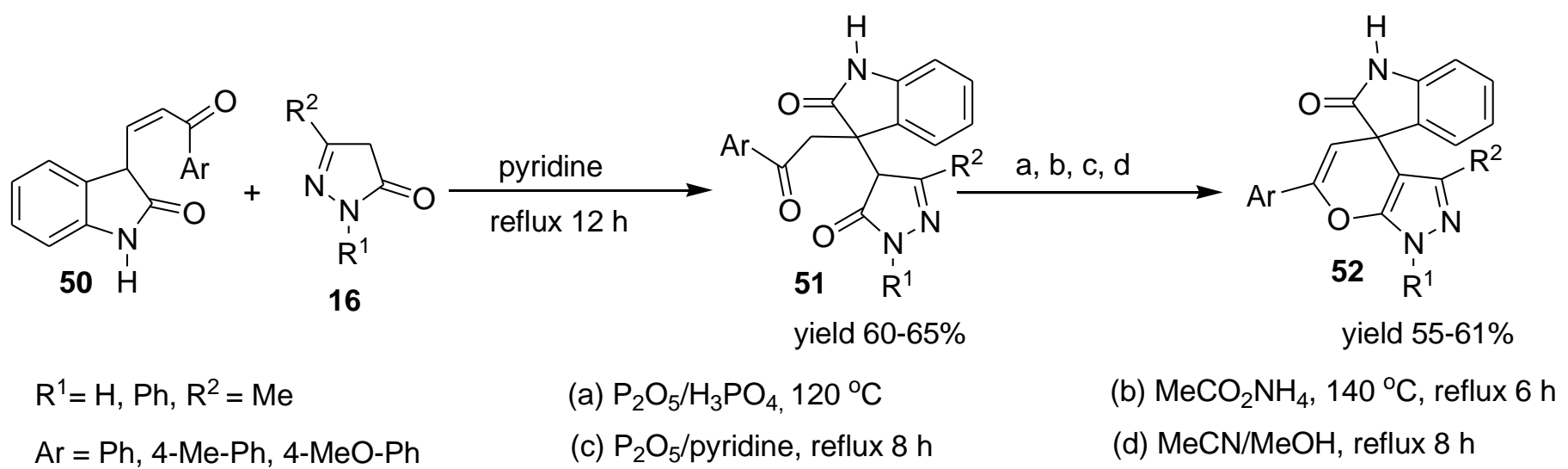

\section{Scheme 16}

Parmar and co-workers treated various aldehydes with allyl/prenyl bromide in DMF under catalytic effect of anhydrous $\mathrm{K}_{2} \mathrm{CO}_{3}$ to obtain substituted benzaldehydes 53, which when refluxed with pyrazolone 16 in 
xylene/acetonitrile containing tetrabutylammonium hydrogen sulphate ( $25 \mathrm{~mol} \%$ ) gave benzopyran-annulated pyrano[2,3-c]pyrazoles (54), which can also be reduced to aminopyranopyrazoles 55 (Scheme 17). ${ }^{28}$<smiles>[R]/C([PH3+])=C/COc1ccc(/N=N\Br)cc1C=O</smiles>

53

$\mathrm{Ar}=\mathrm{Ph}, 4-\mathrm{Cl}-\mathrm{Ph}$

$\mathrm{R}=\mathrm{H}, \mathrm{Me}$<smiles>[R]C1=NN([R])C(=O)C1</smiles>

16

$\mathrm{R}^{2}=\mathrm{Ph}, \mathrm{Me}$

$\mathrm{R}^{1}=\mathrm{Ph}$, 4-Me-Ph, 3-Cl-Ph

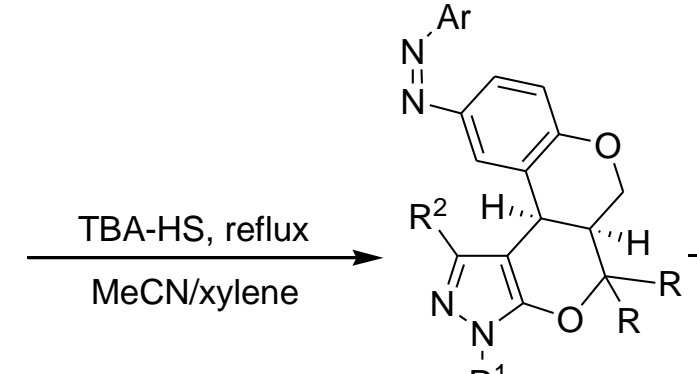

$\mathrm{R}^{1} 54$

yield $68-88 \%$

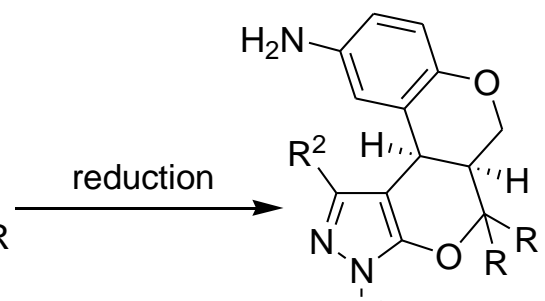

$\mathrm{R}^{1} 55$

\section{Scheme 17}
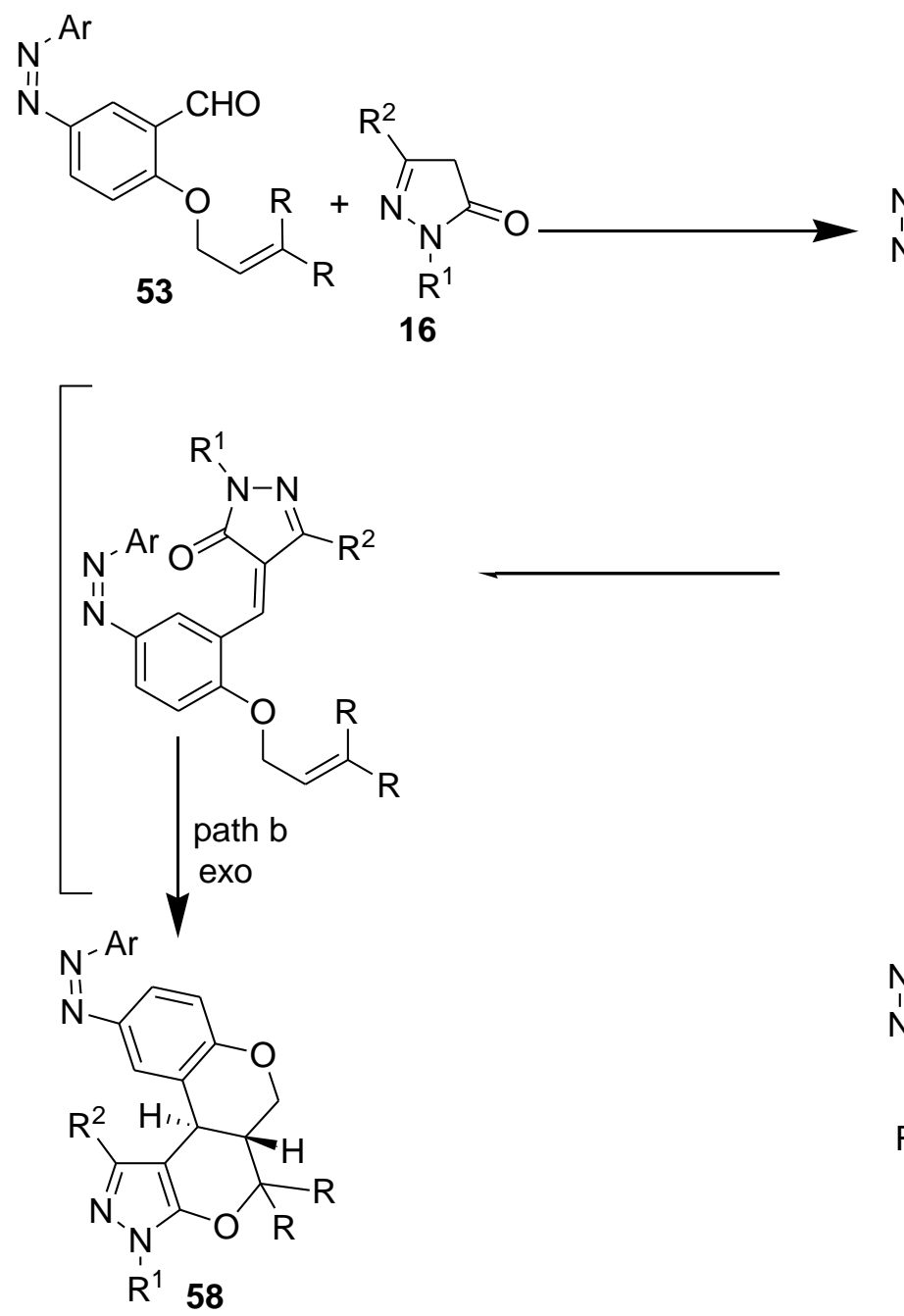<smiles>[R]C([R])=CCOc1ccc(N=N[Te])cc1/C=C1/C(=O)N([R7])N=C1[R]</smiles>

56

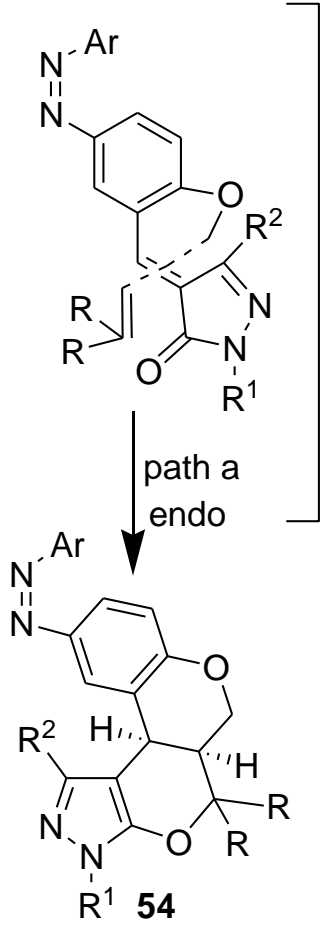

$\mathrm{R}^{1}=\mathrm{Ph}$, 4-Me-Ph, 3-Cl-Ph
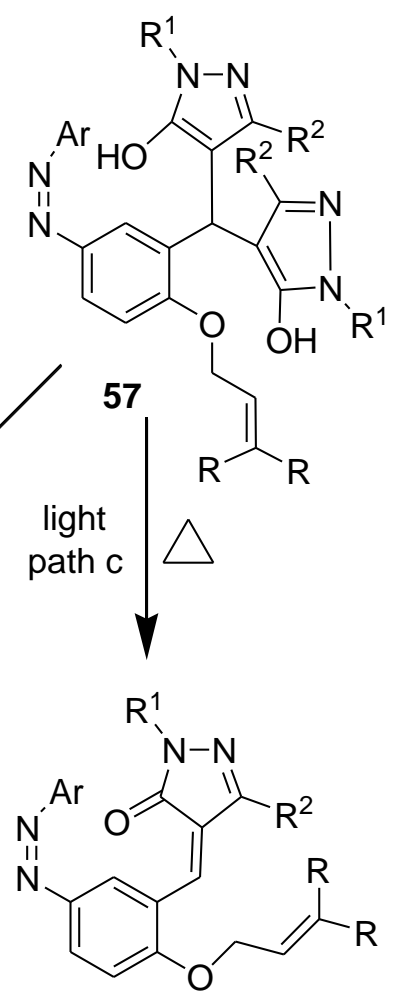

56<smiles>[R]C1=NN([R])C(=O)C1</smiles>

16 $\mathrm{R}^{2}=\mathrm{Ph}, \mathrm{Me}$

\section{Scheme 18}

The reaction mechanism is believed to involve a domino/Knoevenagel-hetero-Diels-Alder sequence including attack of TBA-HS on pyrazolone and generating a reactive tetrabutyl ammoniumpyrazolonate, which 
reacts with aldehydes to form the Knoevenagel adduct $\mathbf{5 6}$ and Knoevenagel-Michael adduct $\mathbf{5 7 .}{ }^{28}$ The synthesis of the latter, was confirmed by spectroscopic data and its conversion to Knoevenagel adduct $\mathbf{5 6}$ and pyrazolone $\mathbf{1 6}$ under the influence of heat, light, or long time storage (path c). Similarly, intermediate $\mathbf{5 7}$ under reflux, afforded $\mathbf{5 4}$ and $\mathbf{5 8}$ which supported the assumption that the initially formed Michael adduct is converted into the Knoevenagel intermediate on subsequent reflux (Scheme 18). Stereochemistry of reaction was predicted as endo- (path a) and exo- (path b) of dienophile but, NMR data revealed the cis- form $\mathbf{5 4}$ as dominant.

$\alpha, \beta$-Unsaturated nitriles being versatile synthons have been used by Elgemeie and co-workers. ${ }^{29}$ In one scheme of reaction, (2-cyano-3-furan/thiophen-2-yl)acrylonitrile (59) was refluxed with 3-aminopyrazolin-5one (60) and pyrazolidin-3,5-dione (61) in the presence of base which, catalyzed Michael addition of the pyrazole methylene to acrylonitrile, followed by carbonyl attack at the cyanocarbon to afford 3-amino pyrano[2,3-c]pyrazoles (62) and 3-oxo-pyrano[2,3-c]pyrazoles (63) respectively (Scheme 19).

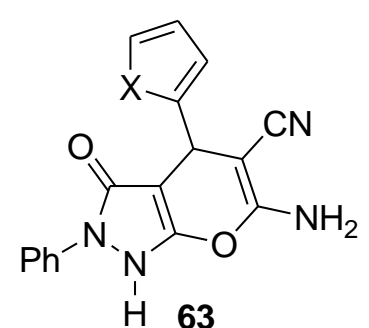

yield $70-80 \%$

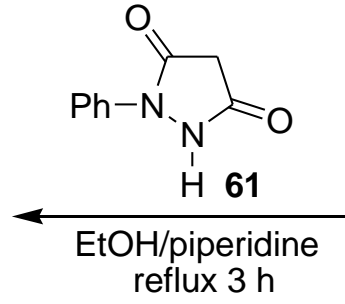

reflux $3 \mathrm{~h}$

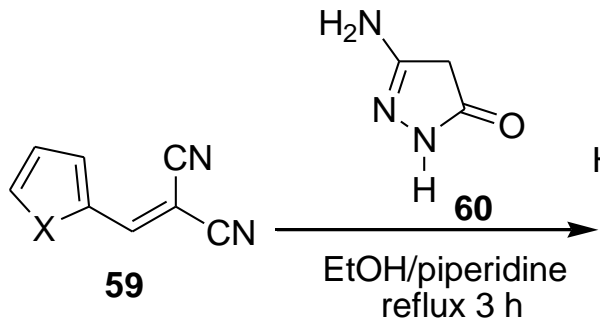

$\mathrm{X}=\mathrm{S}, \mathrm{O}$

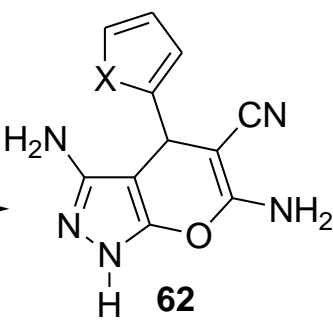

yield $75-82 \%$

\section{Scheme 19}

Similarly, 64 reacted with 3-aminopyrazolin-5-one (60) and pyrazolidin-3,5-dione (61) and proceeded via elimination of water/ethanol to form 3-amino-6-phenyl/hydroxypyrano[2,3-c]pyrazoles (65) and 3-oxo-6phenyl/hydroxypyrano[2,3-c]pyrazoles (66) respectively ${ }^{29}$ (Scheme 20).

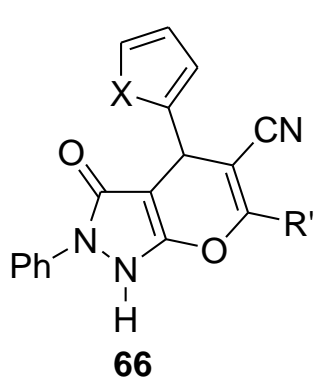

yield $72-85 \%$

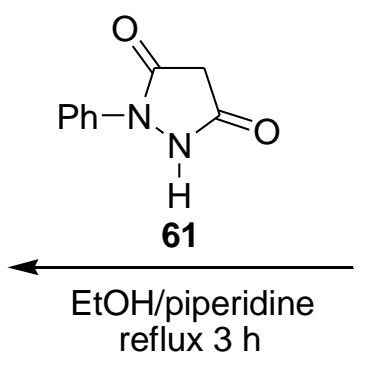

$\mathrm{R}=\mathrm{Ph}, \mathrm{OEt}$

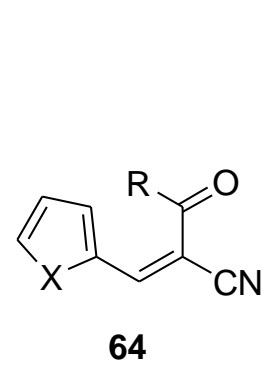

$\mathrm{R}^{\prime}=\mathrm{Ph}, \mathrm{OH}$

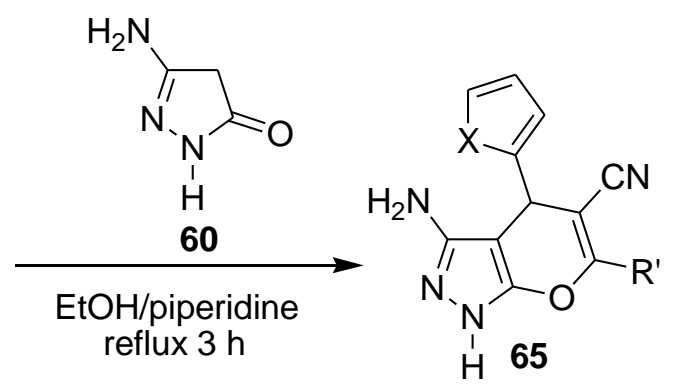

$\mathrm{X}=\mathrm{S}, \mathrm{O}$

yield $65-90 \%$

\section{Scheme 20}

Abdou and co-workers, in a simple procedure, refluxed various alkene derivatives 67 and pyrazolones in piperidine containing ethanolic solution to produce a variety of pyranopyrazoles bearing carbonitrile, hydroxyl or a phenyl group at the 6-position ${ }^{30}$ (Scheme 21). 
<smiles>[R]C1=NN([R1](C)C)C(=O)C1</smiles>

16<smiles>[R]C(Br)=C([Y])C#N</smiles>

67<smiles>[Y]C1=C(C#N)C([R])(Br)c2c([R])nn([R5])c2O1</smiles>

$\mathrm{X}=\mathrm{CN}, \mathrm{CO}_{2} \mathrm{Et}, \mathrm{COPh}$ $X^{\prime}=\mathrm{CN}, \mathrm{OH}, \mathrm{Ph}$ yield $52-94 \%$$$
\text { yie }
$$

\section{Scheme 21}

$\mathrm{R}^{1}=\mathrm{H}, \mathrm{Ph}$

$\mathrm{R}^{3}=\mathrm{H}, \mathrm{Ph}, 4-\mathrm{MeO}-\mathrm{Ph}, 9-$ fluorenylidenyl

$\mathrm{R}^{2}=\mathrm{Me}$

Pasternak and co-workers prepared and condensed the fluoralkylophosphonate bearing ketone 69 with malononitrile followed by dehydration with thionyl chloride or phosphorus pentoxide to yield intermediate $\mathbf{7 0}$ (Scheme 22). ${ }^{31}$<smiles>[R]C(=O)C(F)(F)P(=O)(OCC)OCCCO</smiles>

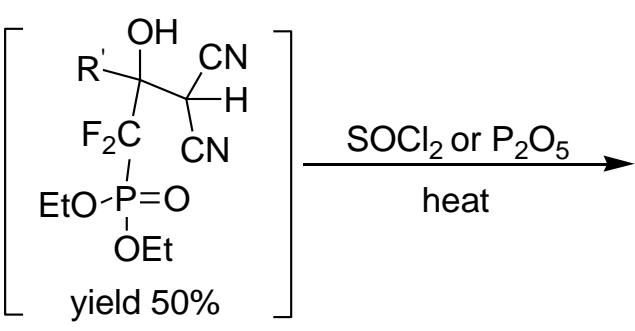

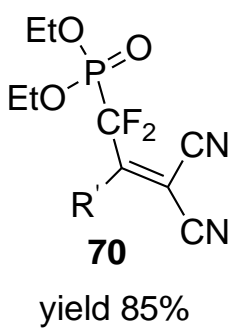

\section{Scheme 22}

The intermediate $\mathbf{7 0}$ condensed at C-4 of pyrazolone $\mathbf{1 6}$ followed by cyclization to form pyranopyrazoles $\mathbf{7 1}{ }^{31}$ Similarly, alkenes $\mathbf{7 0}$ reacted with dimedone $\mathbf{7 2}, \mathbf{1 - u n / s u b s t i t u t e d ~ a m i n o p y r a z o l e s ~} \mathbf{7 3}, \mathbf{7 4}$, aminopyridine 75 and mixture of aniline and acetone to form tetrahydrochromene 76, pyrazolopyrimidines 77, pyrazolopyridine 78, benzopyrimidine $\mathbf{7 9}$ and pyridine derivatives $\mathbf{8 0}$. It was observed that unsubstituted aminopyrazole cyclized at the $\mathrm{N}-1$ position affording pyrazolopyrimidine while, substituted aminopyrazoles cyclized at the exocyclic $-\mathrm{NH}_{2}$ group and gave pyrazolopyridines (Scheme 23). Structures were confirmed by $\mathrm{X}$ ray studies. 


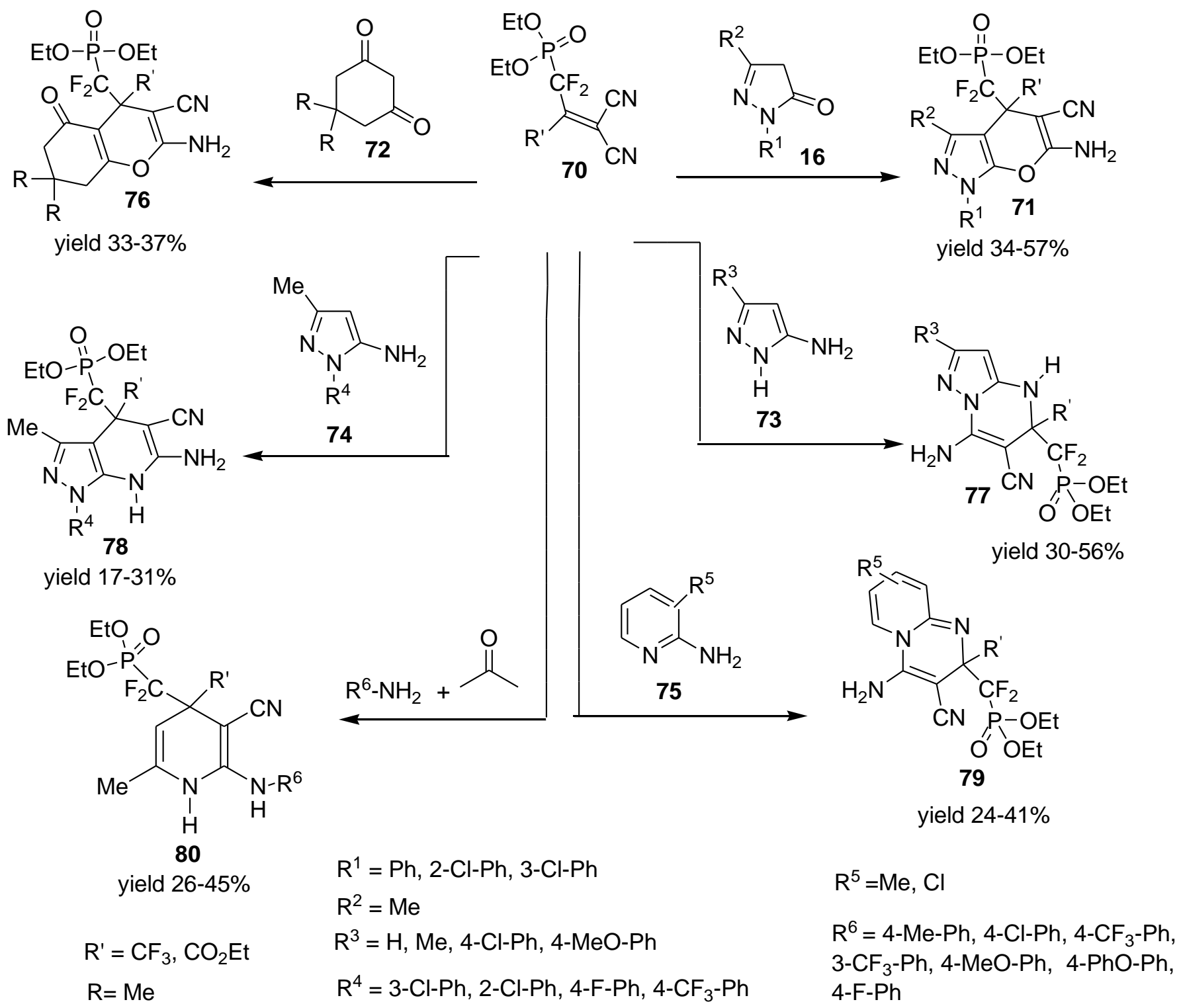

\section{Scheme 23}

Similarly, fluoroketone $\mathbf{8 1}$ and malononitrile were treated either by reported method or with little modification to obtain a slightly modified alkene 1,1-dicyano-2,2-bis(triflouromethyl)ethylene (82) (Scheme 24). ${ }^{32}$ The resultant alkenes 82 reacted with pyrazol-5-one to produce fluorinated pyranopyrazoles 83 (Scheme 25). Reaction of this alkene with acyclic amidine and aminopyrazole followed similar fashion as above. X-Ray studies of compounds confirm structures.

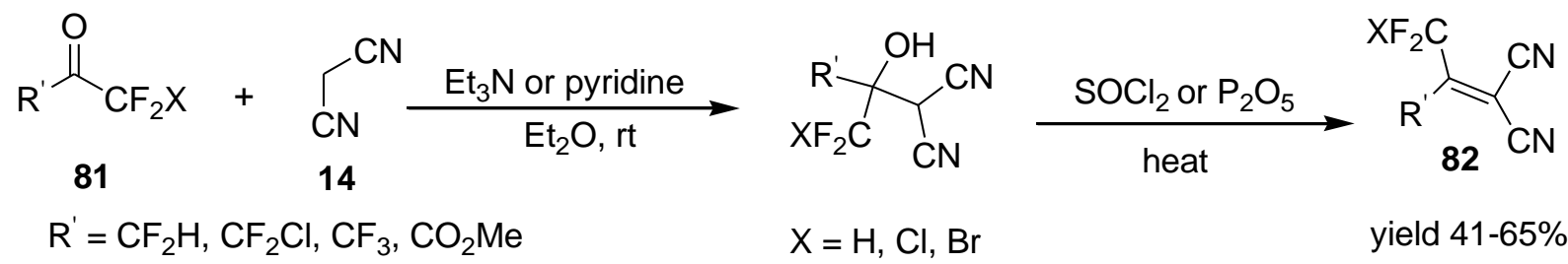


$\mathrm{R}^{2}$<smiles>[3H]N1N=C([Te])CC1=[OH+]</smiles>

16<smiles>[Y7]CC([R])=C(C#N)C#N</smiles>

82

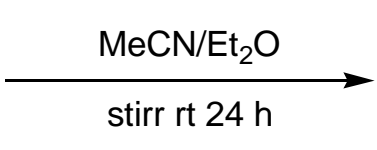<smiles>[R2]c1nn([R1])c2c1C([R])(C)C(C#N)=C(N)O2</smiles>

yield $26-95 \%$

$\mathrm{X}=\mathrm{H}, \mathrm{Cl}, \mathrm{Br}$

$\mathrm{R}^{\prime}=\mathrm{CF}_{2} \mathrm{H}, \mathrm{CF}_{2} \mathrm{Cl}, \mathrm{CF}_{3}, \mathrm{CO}_{2} \mathrm{Me}$

$\mathrm{R}^{1}=\mathrm{Ph}, 4-\mathrm{F}-\mathrm{Ph}, 2$,6-dichloro-4- $\mathrm{CF}_{3}-\mathrm{Ph}$

$\mathrm{R}^{2}=\mathrm{Me}$

\section{Scheme 25}

Abdelrazek and co-workers prepared 4-heteroaryl pyranopyrazoles $\mathbf{1 5}$ by refluxing benzylide derivatives with pyrazolones in ethanolic solvent containing piperidine catalyst (Scheme 26). ${ }^{33,34}$ All compounds exhibited moderate molluscicidal activity against Biomphalaria alexandrina snails.

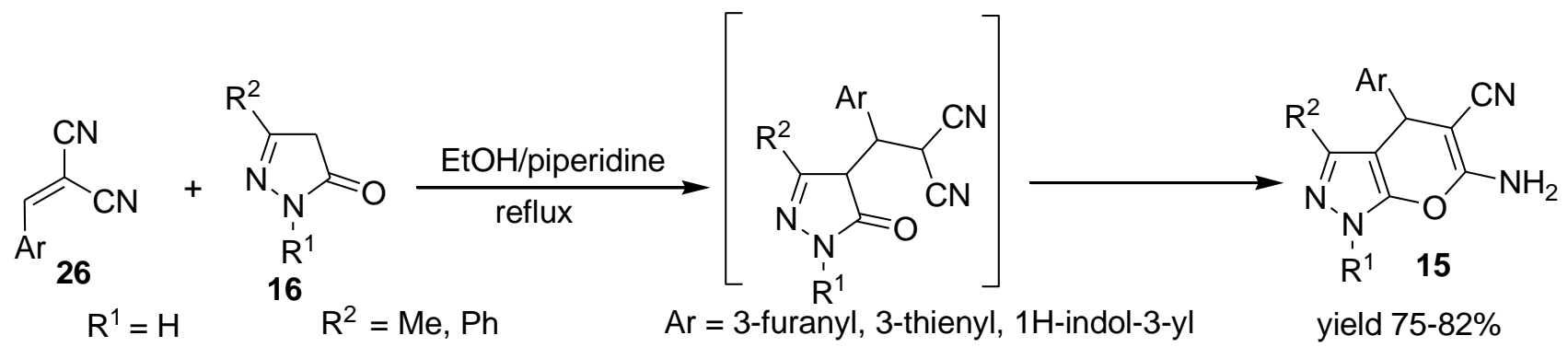

\section{Scheme 26}

In addition to these methods, Maruoka et al. adopted ring transformation and cyclization procedure by treating spirocyclopropanepyrazoles $\mathbf{8 4}$ and chloro acetonitrile in DMF solvent containing sodium hydride either via one pot or two steps involving synthesis of intermediate, cyanomethoxypyrazole $\mathbf{8 5}$ which further cyclized to 6-cyano-5-disubstituted pyranopyrazoles (86) (Scheme 27). ${ }^{35}$

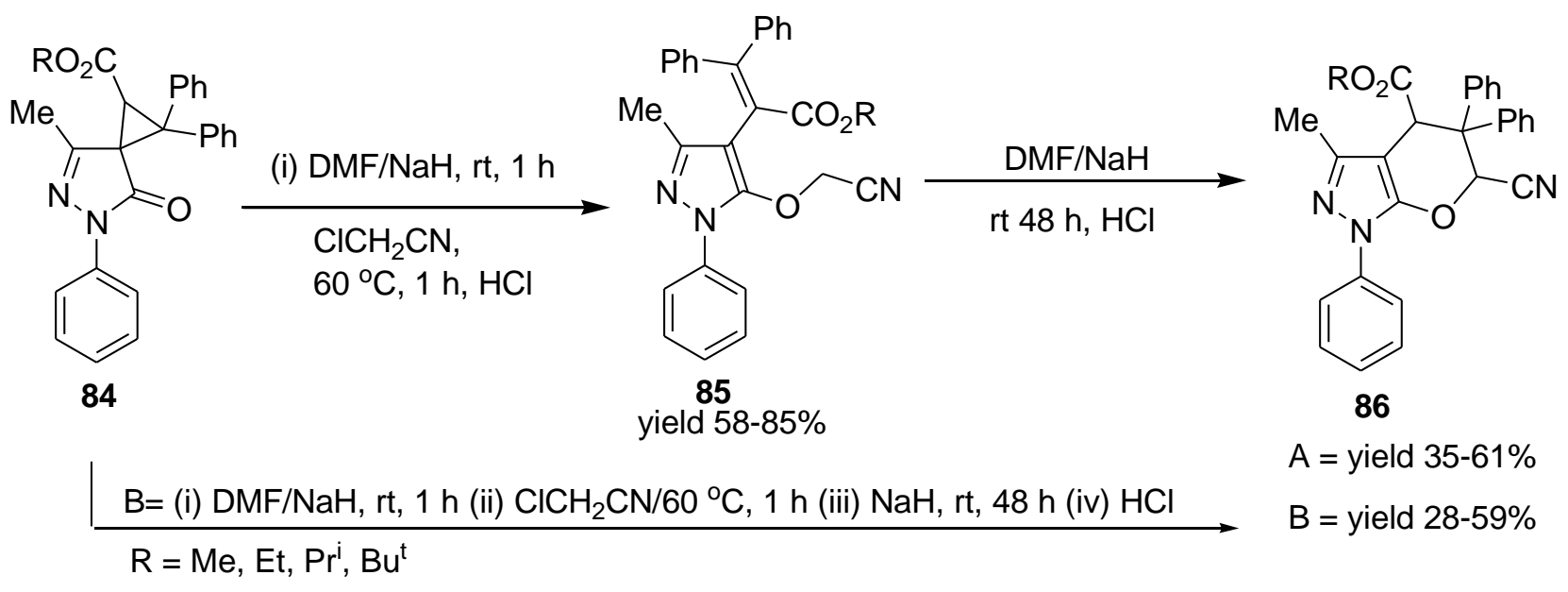

\section{Scheme 27}


The reaction was also tried using potassium $t$-butoxide in $\mathrm{N}, \mathrm{N}$-dimethylformamide and potassium $t$ butoxide in $t$-butyl alcohol, but failed. ${ }^{35}$ Spirocyclopropanepyrazoles were subjected to ring opening using either using $\mathrm{NaH} / \mathrm{DMF}$, or titanium (IV) chloride in chloroform and afforded pyrazol-3-one $\mathbf{8 7}$ and carboxylic acid 88 in case of butyl acetate (Figure 6).

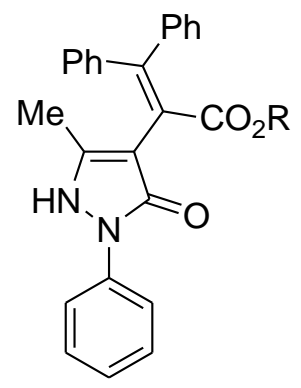

87

yield $86-99 \%$

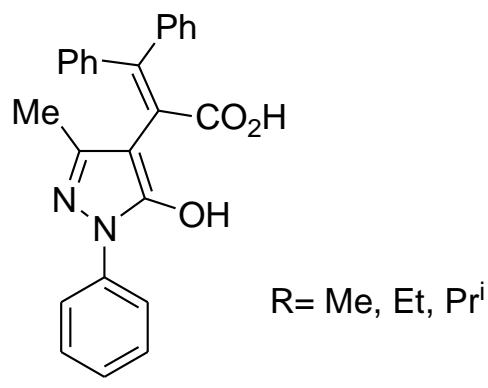

88

yield $73-93 \%$

Figure 6

\subsection{Three components synthesis (MCRs)}

Most of these examples used pyrazolone, aldehydes and malononitrile and allowed to react together under different reaction conditions to form a variety of pyranopyrazoles. Jin and co-workers added $p$ dodecylbenzenesulfonic acid (DBSA), as phase transfer catalyst, for uniform dispersion of reactants to get a better yield (84-94\%) (Scheme 28 A). ${ }^{36}$ Initially, the reaction was tested in the absence of catalyst and yielded traces of product or no product as in case of 4-dimethylaminobenzaldehyde, which has strong electron donating dimethylamino group that has significant contributions of the quinoid resonance form, hence reactivity decreased $\mathbf{8 9 - 9 0}$ (Figure 7).<smiles>CN(C)c1ccc(C=O)cc1</smiles>

89

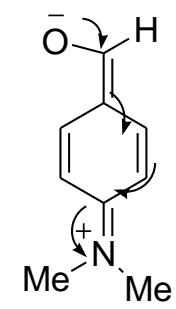

90

\section{Figure 7}

In another attempt, various PTC namely, TBAB, DBSA, sodium dodecyl sulphate (SDS) and HTMAB were tested for similar reactants where HTMAB was found best in term of yield ${ }^{37}$ (Scheme 28 B). The reaction conditions worked equally for aromatic aldehydes with electron-withdrawing and donating substituents, but did not proceed for aliphatic aldehydes probably, due to their low reactivity. Prajapati and co workers refluxed substituted aldehydes, malononitrile and 1-(2,4-dinitrophenyl)-3-methylpyrazol-5-one in ethanol containing 
piperidine catalyst to give the respective pyranopyrazoles which were found to be good antibacterial agents (Scheme $28 \mathrm{C}) .^{38}$<smiles>[R]C1=NN([R7])C(=[OH+])C1</smiles>

16<smiles>N#CC[C+]C=CC(=O)[Hg]</smiles>

91

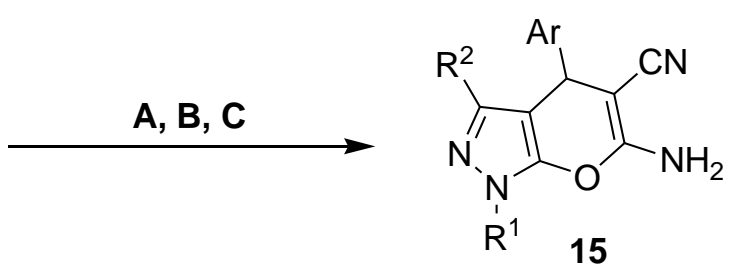

\begin{tabular}{|c|c|c|c|c|c|}
\hline Scheme & $\mathbf{R}^{1}$ & $\mathbf{R}^{2}$ & $\mathrm{Ar}$ & Condition & Yiled \\
\hline A & $\mathrm{Ph}$ & $\mathrm{Me}$ & $\begin{array}{l}\mathrm{Ph}, 4-\mathrm{Me}-\mathrm{Ph}, 4-\mathrm{MeO}-\mathrm{Ph}, 2-\mathrm{Cl}-\mathrm{Ph}, 3- \\
\mathrm{Cl}-\mathrm{Ph}, 4-\mathrm{Cl}-\mathrm{Ph}, 3-\mathrm{NO}_{2}-\mathrm{Ph}, 4-\mathrm{NO}_{2}-\mathrm{Ph} \text {, } \\
\text { 4-HO-Ph, 2,4-dichloro-Ph, 3,4- } \\
\text { dioxymethylene-Ph }\end{array}$ & $\begin{array}{l}\mathrm{H}_{2} \mathrm{O}, 10 \mathrm{~mol} \% \\
\mathrm{DBSA}, 60^{\circ} \mathrm{C}, 3 \mathrm{~h}\end{array}$ & $84-94 \%$ \\
\hline B & $\mathrm{Ph}$ & $\mathrm{Me}$ & $\begin{array}{l}\mathrm{Ph}, 2-\mathrm{Cl}-\mathrm{Ph}, 3-\mathrm{Cl}-\mathrm{Ph}, 4-\mathrm{Cl}-\mathrm{Ph}, 4-\mathrm{Me}- \\
\mathrm{Ph}, 4-\mathrm{MeO}-\mathrm{Ph}, 4-\mathrm{NO}_{2}-\mathrm{Ph}, 3-\mathrm{NO}_{2}-\mathrm{Ph} \text {, } \\
\text { 2,4-dichloro- } \mathrm{Ph}, 4-\mathrm{HO}-\mathrm{Ph}, 3,4- \\
\text { dioxymethylene-Ph }\end{array}$ & $\begin{array}{l}\mathrm{H}_{2} \mathrm{O}, 10 \mathrm{~mol} \% \\
\mathrm{HTMAB}, 85-90^{\circ} \mathrm{C}\end{array}$ & $79-92 \%$ \\
\hline C & 2,4-dinitro-Ph & Me & $\begin{array}{l}\mathrm{Ph}, 4-\mathrm{Cl}-\mathrm{Ph}, 2-\mathrm{Cl}-\mathrm{Ph}, 4-\mathrm{MeO}-\mathrm{Ph}, 3- \\
\mathrm{NO}_{2}-\mathrm{Ph}, 4-\mathrm{NMe}_{2}-\mathrm{Ph}, 2-\mathrm{HO}-\mathrm{Ph}, 4-\mathrm{HO}- \\
\mathrm{Ph}, 3,4-\text { dimethoxy-Ph, 3-MeO-4-HO- } \\
\mathrm{Ph}\end{array}$ & $\begin{array}{l}\text { EtOH, piperidine, } \\
\text { reflux } 3 \mathrm{~h}\end{array}$ & $70-76 \%$ \\
\hline
\end{tabular}

\section{Scheme 28}

Pyranopyrazoles bearing a triflouromethyl group at the 3-position were obtained by reaction of aldehydes, malononitrile and trifluoromethylpyrazol-5-one, in water as solvent without catalyst at $90{ }^{\circ} \mathrm{C}$, in good yields in 3-5 $\mathrm{h}$ (Scheme $29 \mathrm{~A}$ ). ${ }^{39}$ The yield of the product is not affected by the electronic nature of the aryl substituents. Bhavanarushi and co-workers prepared flouropyranopyrazoles by grinding similar reactants in a pestle mortar using DBU as catalyst and established the molecular mechanism for DNA binding of resultant products (Scheme 29 B). ${ }^{40}$ Microwave irradiation to eliminate the need of heat, enhances the rate of reaction, is a widely applicable technique and has been used for the synthesis of pyranopyrazoles within 2-8 min in dry ethanol containing piperidine catalyst (Scheme $29 \mathrm{C}$ ). ${ }^{41}$ Diaminopyrano[2,3-c]pyrazoles were prepared at room temperature in ethanolic solvent containing secondary amine/organic bases such as pyridine, piperidine and pyrrolidine. $^{42}$ The resultant compounds were found to be potential antibacterial agent while, some of them also exhibited antifungal activity (Scheme 29 D). 


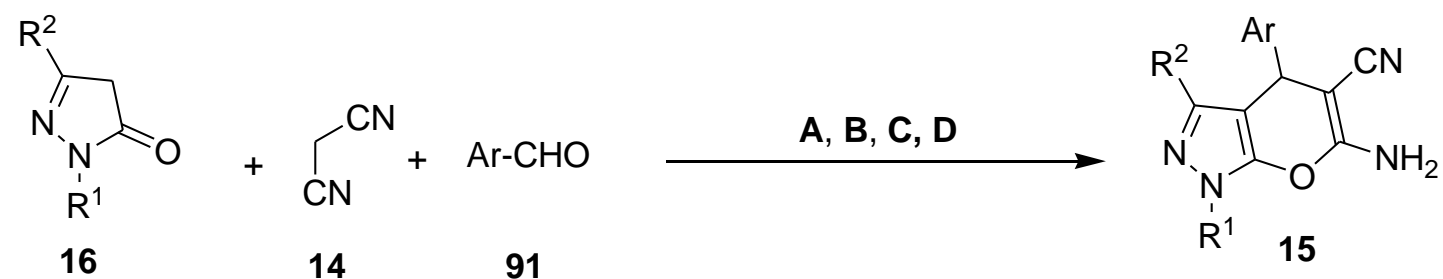

\begin{tabular}{|c|c|c|c|c|c|}
\hline Scheme & $\mathbf{R}^{1}$ & $\mathbf{R}^{2}$ & $\mathrm{Ar}$ & Condition & Yield \\
\hline A & $\mathrm{Ph}$ & $\mathrm{CF}_{3}$ & $\begin{array}{l}\mathrm{Ph}, 4-\mathrm{Cl}-\mathrm{Ph}, 4-\mathrm{Br}-\mathrm{Ph}, 4-\mathrm{F}-\mathrm{Ph}, 3- \\
\mathrm{NO}_{2}-\mathrm{Ph}, 4-\mathrm{NO}_{2}-\mathrm{Ph}, 2-\mathrm{F}-\mathrm{Ph}, 3,4,5- \\
\text { trimethoxy-Ph, 4-CHO-Ph, 3-F-Ph, } \\
\text { 4-HO-3- } \mathrm{NO}_{2}-\mathrm{Ph}\end{array}$ & $\begin{array}{l}\mathrm{H}_{2} \mathrm{O}, 90^{\circ} \mathrm{C} \\
3-5 \mathrm{~h}\end{array}$ & $78-90 \%$ \\
\hline B & $\begin{array}{l}\mathrm{Ph}, 3-\mathrm{Cl}-\mathrm{Ph}, \\
4-\mathrm{F}-\mathrm{Ph}\end{array}$ & $\mathrm{CF}_{3}$ & $\begin{array}{l}\mathrm{Ph}, 4-\mathrm{NO}_{2}-\mathrm{Ph}, 3-\mathrm{MeO}-\mathrm{Ph}, 4-\mathrm{Me}- \\
\mathrm{Ph}, 4-\mathrm{F}-\mathrm{Ph}, 4-\mathrm{MeO}-\mathrm{Ph}, 2 \text {-furanyl, } \\
\text { 2-thienyl }\end{array}$ & $\begin{array}{l}\text { DBU, grinding at } \\
\mathrm{rt}\end{array}$ & $81-88 \%$ \\
\hline C & $\mathrm{Ph}$ & $\mathrm{Me}$ & $\begin{array}{l}\mathrm{Ph}, 4-\mathrm{Cl}-\mathrm{Ph}, 4-\mathrm{Br}-\mathrm{Ph}, 4-\mathrm{MeO}-\mathrm{Ph} \\
\text { 4- } \mathrm{NO}_{2}-\mathrm{Ph}, 3-\mathrm{NO}_{2}-\mathrm{Ph}\end{array}$ & $\begin{array}{l}\text { piperidine/EtOH, } \\
\text { MW,2-8 min }\end{array}$ & $61-91 \%$ \\
\hline D & $\mathrm{Ph}$ & $\mathrm{NH}_{2}$ & $\begin{array}{l}\mathrm{Ph}, 2-\mathrm{Cl}-\mathrm{Ph}, 3-\mathrm{Cl}-\mathrm{Ph}, 4-\mathrm{Cl}-\mathrm{Ph}, 4- \\
\mathrm{Me}-\mathrm{Ph}, 4-\mathrm{MeO}-\mathrm{Ph}, 2-\mathrm{Br}-\mathrm{Ph}, 3-\mathrm{Br}- \\
\mathrm{Ph}, 4-\mathrm{Br}-\mathrm{Ph}, 2-\mathrm{NO}_{2}-\mathrm{Ph}, 3-\mathrm{NO}_{2}-\mathrm{Ph} \text {, } \\
\text { 4-NO }{ }_{2}-\mathrm{Ph}, 2-\mathrm{HO}-\mathrm{Ph} \text {, 4-HO-Ph, 4-F- } \\
\mathrm{Ph}, 2 \text { - } 4 \text {-dichloro- } \mathrm{Ph}, 2,6 \text {-dichloro- } \\
\mathrm{Ph}, 3,4-\text { dimethoxy-Ph, 2,5- } \\
\text { dimethoxy-Ph, 3,4,5-trimethoxy-Ph }\end{array}$ & $\begin{array}{l}\text { sec. amine, } \\
\text { EtOH, rt, } \\
15-60 \text { min }\end{array}$ & $64-90 \%$ \\
\hline
\end{tabular}

\section{Scheme 29}

Pyrazolone and aldehydes were refluxed together with malononitrile to give 6-aminopyrano[2,3c]pyrazoles (15), or with 3-oxo-3-phenylpropanenitrile (92) to afford 6-phenylpyrazolo[3,4-b]pyridine-5carboxylate (93). ${ }^{43}$ These compounds showed remarkable anticancer activity on human tumor cell lines (Scheme 30).

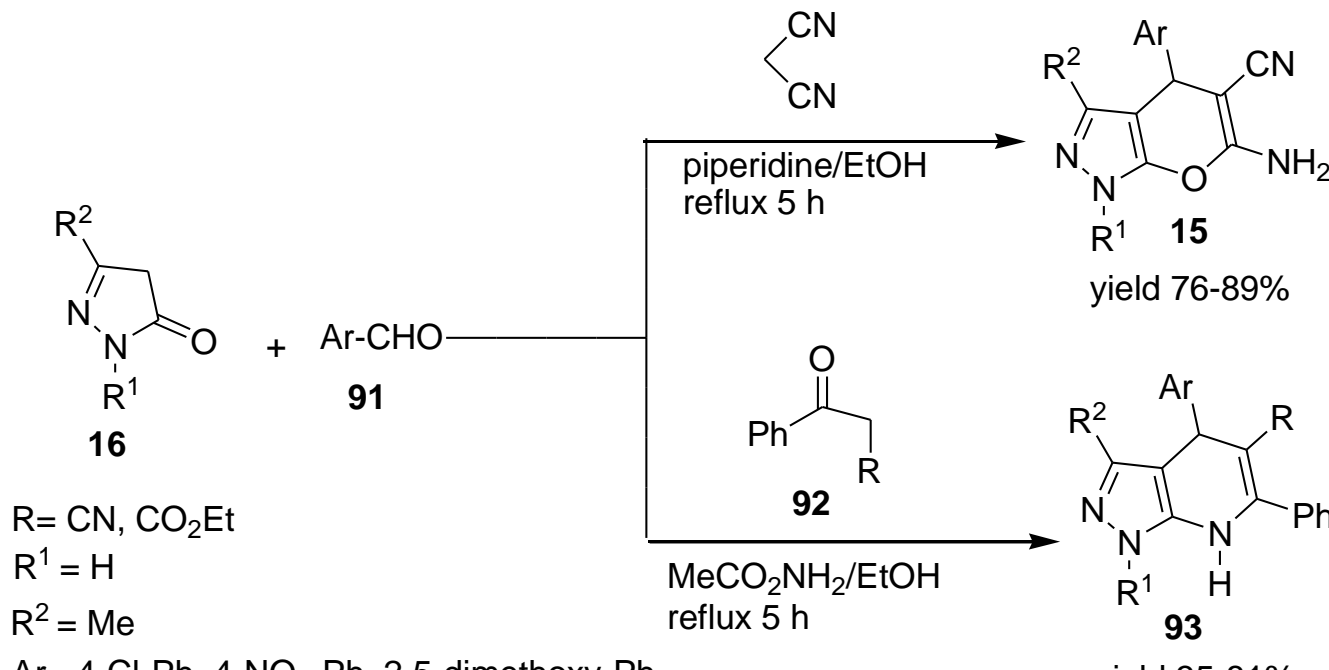

Scheme 30 
In the literature, $36,37,39,42$ the most reported mechanism involves fast Knoevenagel condensation of aldehyde and malononitrile to form $\alpha$-cyanocinnamonitrile derivatives, which are attacked by the active methylene of the pyrazolone $\mathbf{9 4}$ to give the intermediate $\mathbf{9 5}$. Tautomerization of $\mathbf{9 5}$ possibly to $\mathbf{9 6}$ is followed by intramolecular nucleophilic attack of $\mathrm{OH}$ group on the cyano moiety to afford a cyclic intermediate 97 which, tautomerizes to give final pyranopyrazoles 15 (Scheme 31).

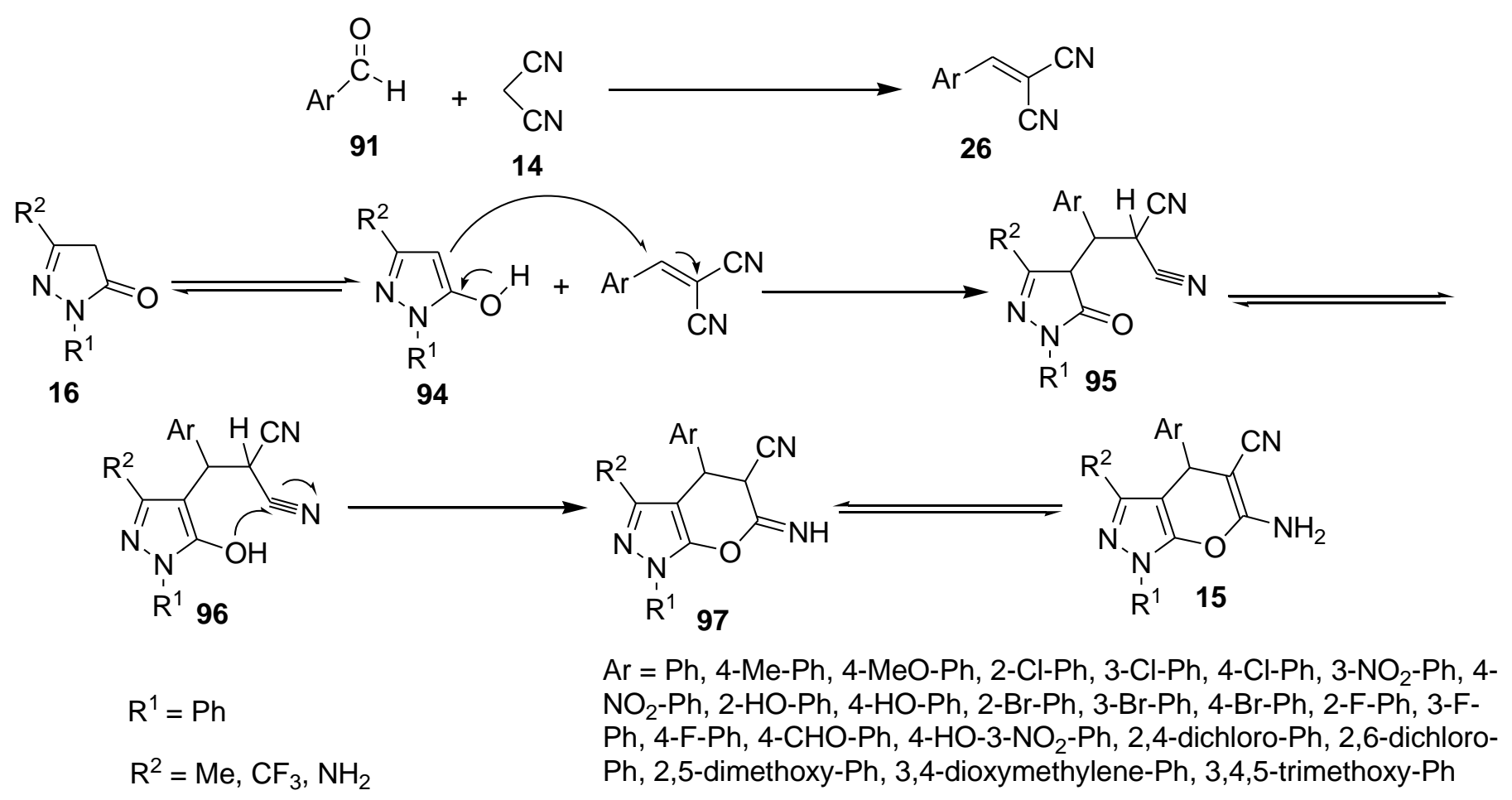

Scheme 31. Mechanism.

Heating, irradiation and solvent-free, environmental friendly method was developed by grinding the aryl aldehydes and malononitrile with pyrazol-5-one or dimedone (72) in the presence of 5-25 mol\% D,L-proline catalyst to get pyranopyrazoles 15 and benzo[b]pyrans (98) respectively (Scheme 32). ${ }^{44}$<smiles>[R]C1([R9])CC(=O)C2=C(C1)OC(N)=C(C#N)C2[Al]</smiles>

yield $80-95 \%$

$\mathrm{R}^{1}=\mathrm{Ph}$<smiles>[R]C1([R])CC(=O)CC(=O)C1</smiles>

20 mol\% proline
A

91<smiles>N#CC[O+]</smiles>

$\mathrm{Ar}=\mathrm{Ph}, 2-\mathrm{Cl}-\mathrm{Ph}, 3-\mathrm{Cl}-\mathrm{Ph}, 4-\mathrm{Cl}-\mathrm{Ph}, 4-\mathrm{Br}-\mathrm{Ph}, 3-\mathrm{NO}_{2}-\mathrm{Ph}$, 4-NO $\mathrm{N}_{2}-\mathrm{Ph}, 4-\mathrm{HO}-\mathrm{Ph}, 4-\mathrm{Me}-\mathrm{Ph}, 4-\mathrm{MeO}-\mathrm{Ph}, 2,4$-dichloro-Ph

\section{Scheme 32}


A possible mechanism under catalytic effect of $D, L$-proline is proposed which, follows same sequence of steps, but the intermediates are formed by direct interaction of the catalyst with reactants ${ }^{44}$ (Scheme 33 ).

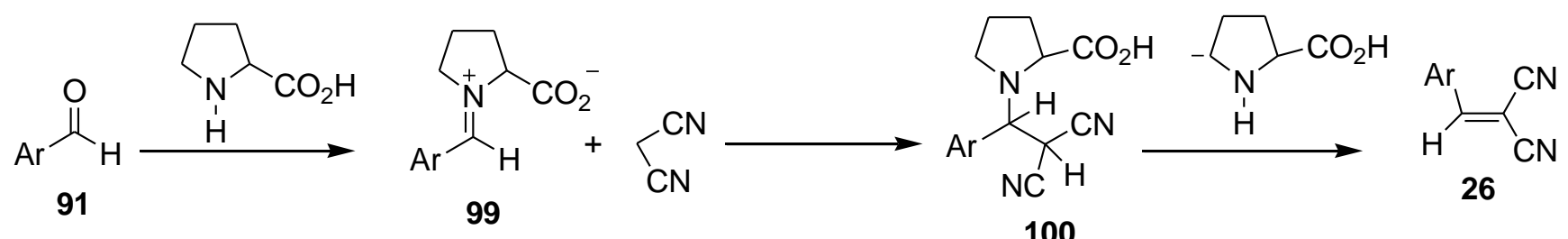<smiles>[R]C1=NN([R17])C(=O)C1</smiles>

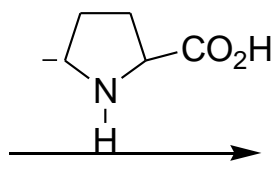

$\mathrm{R}^{1}=\mathrm{Ph}$

$\mathrm{R}^{2}=\mathrm{Me}$<smiles>[R]C1=NN([R])C(=O)C1C(Br)C(C)C#N</smiles><smiles>[R]c1nn([R7])c2c1C(Br)C(C)=C(N)O2</smiles>

$\mathrm{Ar}=\mathrm{Ph}, 2-\mathrm{Cl}-\mathrm{Ph}, 3-\mathrm{Cl}-\mathrm{Ph}, 4-\mathrm{Cl}-\mathrm{Ph}, 4-\mathrm{Br}-\mathrm{Ph}, 3-\mathrm{NO}_{2}-\mathrm{Ph}$, 4-NO $\mathrm{NO}_{2}-\mathrm{Ph}, 4-\mathrm{HO}-\mathrm{Ph}, 4-\mathrm{Me}-\mathrm{Ph}, 4-\mathrm{MeO}-\mathrm{Ph}, 2,4-$ dichloro- $\mathrm{Ph}$

\section{Scheme 33. Mechanism.}

Some protocols developed for two component reactions were also applied to three components synthesis. Thus aromatic aldehydes, malononitrile, pyrazolone and triethylamine were heated in ethanol to give $\mathrm{N}$-unsubstituted pyrano[2,3-c]pyrazoles (28) (Scheme $34 \mathrm{~A}) .^{22}$ Similarly, cinchona alkaloids were also used as catalysts at room temperature with/without drying agents $\left(\mathrm{Na}_{2} \mathrm{SO}_{4}, \mathrm{MS}(4 \AA)^{\mathrm{e}}\right)$, and gave better yield of entioselectively $\left(e e^{c}\right)$ products in some reactions, but poor yields in others ${ }^{17}$ (Scheme $34 \mathrm{~B}$ ).

Kamble and co-workers replaced toxic, volatile solvents ( $\mathrm{MeOH}, \mathrm{EtOH}, \mathrm{MeCN}$ ) with thermally stable, nonvolatile, easily available, miscible and recyclable polyethylene glycol (PEG-400), which increased the yield short reaction times. ${ }^{45}$ Bleaching earth clay, a heterogeneous base used as catalyst due to its selectivity, acidic/basic nature, thermal stability and easy separation by filtration. Substituted benzaldehyde 103 was reacted with pyrazolone and (4-chlorophenyl)acetonitrile (104) containing 10 wt\% of catalyst to get 4,5-diarylpyrano[2,3c]pyrazoles (105) in 73-88\% yields within 20-30 $\mathrm{min}$ (Scheme 35). 


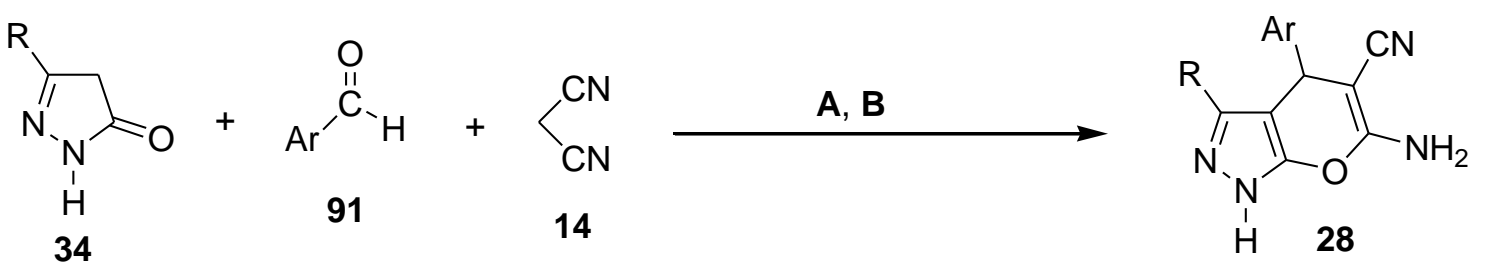

\begin{tabular}{|c|c|c|c|c|}
\hline Scheme & $\mathbf{R}$ & $\mathrm{Ar}$ & Condition & Yield \\
\hline A & $\begin{array}{l}\mathrm{Me}, \mathrm{Et}, \mathrm{Pr}^{\mathrm{n}}, \mathrm{Bu}^{\mathrm{t}} \\
\mathrm{Ph}, \mathrm{CF}_{3} \\
\mathrm{MeOCH}_{2} \\
\mathrm{MeCO}_{2} \mathrm{CH}_{2} \\
\text { 4-Me-Ph-S-CH}\end{array}$ & 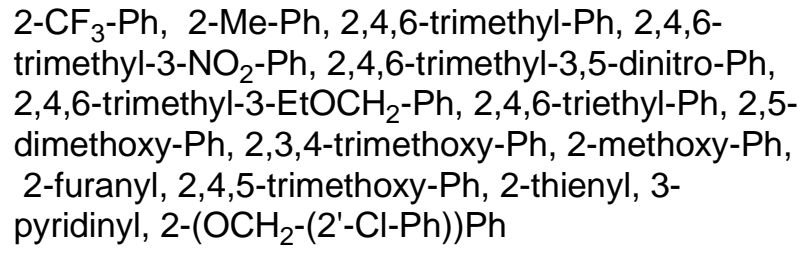 & $\begin{array}{l}\mathrm{EtOH} / \mathrm{Et}_{3} \mathrm{~N} \text {, } \\
\text { heat }\end{array}$ & $52-97 \%$ \\
\hline B & $\mathrm{Me}, \mathrm{Et}, \mathrm{Ph}$ & $\begin{array}{l}\mathrm{Ph}, 4-\mathrm{Me}-\mathrm{Ph}, 4-\mathrm{MeO}-\mathrm{Ph}, 4-\mathrm{Cl}-\mathrm{Ph}, 4-\mathrm{CN}-\mathrm{Ph}, 4- \\
\mathrm{NO}_{2}-\mathrm{Ph}, 3-\mathrm{Br}-\mathrm{Ph}, 4-\mathrm{Br}-\mathrm{Ph}, 4-\mathrm{I}-\mathrm{Ph}, 4-\mathrm{F}-\mathrm{Ph}\end{array}$ & $\begin{array}{l}\mathrm{CH}_{2} \mathrm{Cl}_{2}, \mathrm{rt}, \\
\text { additive } \\
\text { cuperine } \\
5 \mathrm{~mol} \%\end{array}$ & $79-96 \%$ \\
\hline
\end{tabular}

\section{Scheme 34}

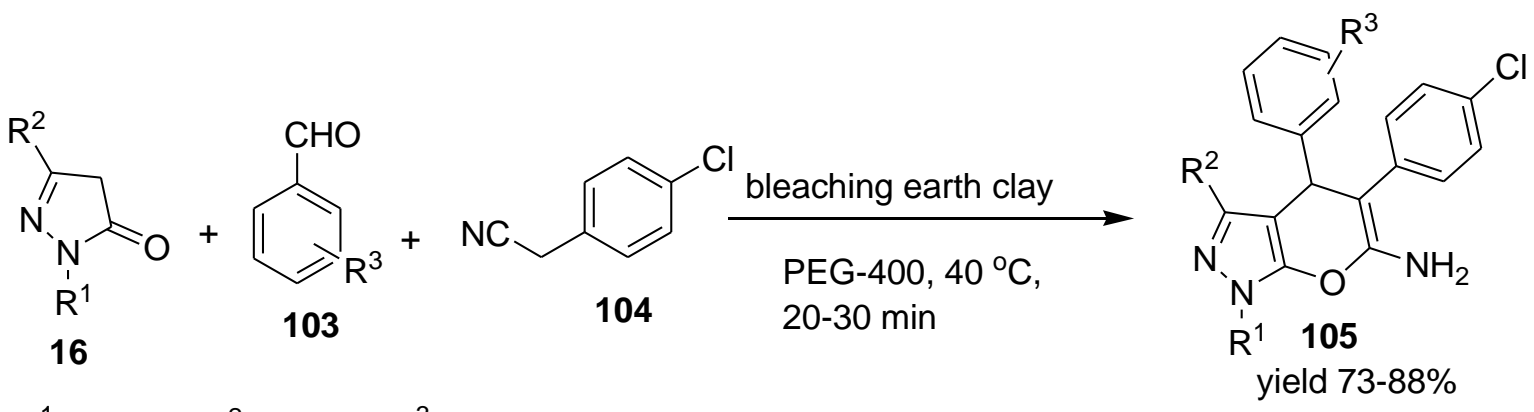

$\mathrm{R}^{1}=\mathrm{H} \quad \mathrm{R}^{2}=\mathrm{Me} \quad \mathrm{R}^{3}=4-\mathrm{Cl}, 4-\mathrm{F}, 3-\mathrm{Br}, 4-\mathrm{OH}, 4-\mathrm{OMe}, 3-\mathrm{OH}, 2-\mathrm{Cl}, 4-\mathrm{NO}_{2}$

\section{Scheme 35}

Dawane et al. also used polyethylene glycol (PEG-400) without catalyst for the reaction of pyrazol-5-one, malononitrile and substituted hetarylaldehydes at $40{ }^{\circ} \mathrm{C} .{ }^{46}$ The reaction condition was found successful for 3substituted-1-phenyl-pyrazol-4-carbaldehyde (106), 5-chloropyrazol-4-carbaldehyde (107), 2,6dichloroquinoline-3-carbaldehyde (108) and 2-chloro-6-methylquinoline-3-carbaldehyde (109) to get various pyranopyrazoles 110-113 (Scheme 36). Antibacterial and antifungal activities of the synthesized compounds were tested and, mostly the analogues were found to be active antibacterials. Moreover, results revealed the position of the halo group affects the biological activity and pyrazolone aldehydes having halogen the 2 position of substituent exhibited both activities. 
<smiles>[R]c1nn([Z17])c2c1C(c1c([R])nn(-c3ccccc3)c1Cl)C(C#N)=C(N)O2</smiles>

yield $88 \%$

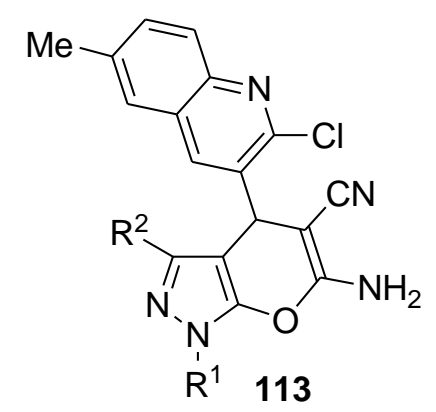

$$
\text { yield } 80 \%
$$

$$
\mathrm{R}^{1}=\mathrm{Ph} \quad \mathrm{R}^{2}=\mathrm{Me}
$$<smiles>[R]c1nn([R7])c2c1C(c1c([R])nn(-c3ccccc3)c1[R])C(C#N)=C(N)O2</smiles>

yield $82-90 \%$

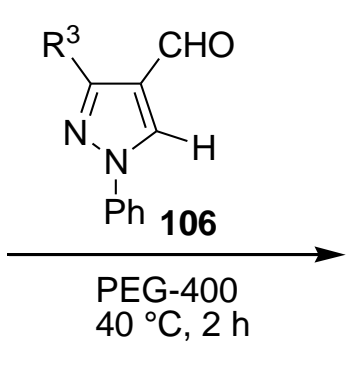

16

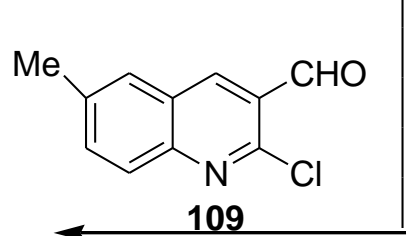

PEG-400

$40^{\circ} \mathrm{C}, 2 \mathrm{~h}$

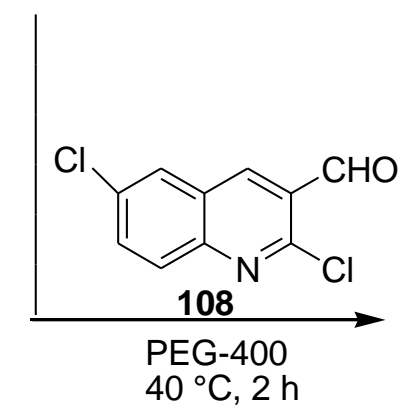

PEG-400 $40{ }^{\circ} \mathrm{C}, 2 \mathrm{~h}$<smiles>[R2]c1nn([R1])c2c1C(c1cc3cc(Cl)ccc3nc1Cl)C(C#N)=C(N)O2</smiles>

$\mathrm{R}^{3}=4-\mathrm{Cl}-\mathrm{Ph}, 4-\mathrm{F}-\mathrm{Ph}, 4-\mathrm{HO}-\mathrm{Ph}, 4-\mathrm{NO}_{2}-\mathrm{Ph}, 4-\mathrm{MeO}-\mathrm{Ph}$

\section{Scheme 36}

Novel heterogeneous, eco-friendly silica sodium carbonate (SSC) catalyzed synthesis of pyranopyrazoles 114 by treating pyrazolone, malononitrile, and substituted benzaldehydes/naphthaldehyde in water/ethanol mixture (1:2) (Figure 8) has been reported. ${ }^{47}$ At first, the catalyst is prepared by drying silica gel 60 at $120{ }^{\circ} \mathrm{C}$, adding thionyl chloride while cooling on ice, keeping cold for $30 \mathrm{~min}$, then refluxing for $48 \mathrm{~h}$ followed by filtration to isolate the silica chloride. Silica chloride and sodium bicarbonate were allowed to react in $n$ hexane, and washed with water to remove remaining sodium bicarbonate. This novel catalyst was found to be effective in small quantity $(1 \mathrm{~mol} \%)$ and reusable without significant loss in activity. The reaction mechanism is represented as Scheme 37.<smiles>[R]c1ccc(C2C(C#N)=C(N)Oc3c2c(C)nn3-c2ccccc2)c([R])c1[R]</smiles>

yield $88-94 \%$
$114(\mathrm{a}-\mathrm{g})=\mathrm{R}^{1}+\mathrm{R}^{2}=\mathrm{H}, \mathrm{R}^{3}=\mathrm{H}, \mathrm{Ph}, \mathrm{MeO}$, $\mathrm{Me}, \mathrm{OCH}_{2} \mathrm{Ph}, \mathrm{CHMe}_{2}$, naphthyl

$114(h)=R^{1}=H, R^{2}=O E t, R^{3}=O H$

114 (i) $=\mathrm{R}^{1}=\mathrm{Cl}, \mathrm{R}^{2}+\mathrm{R}^{3}=\mathrm{H}$

114 (j) $R^{1}+R^{3}=H, R^{2}=B r$

\section{Figure 8}




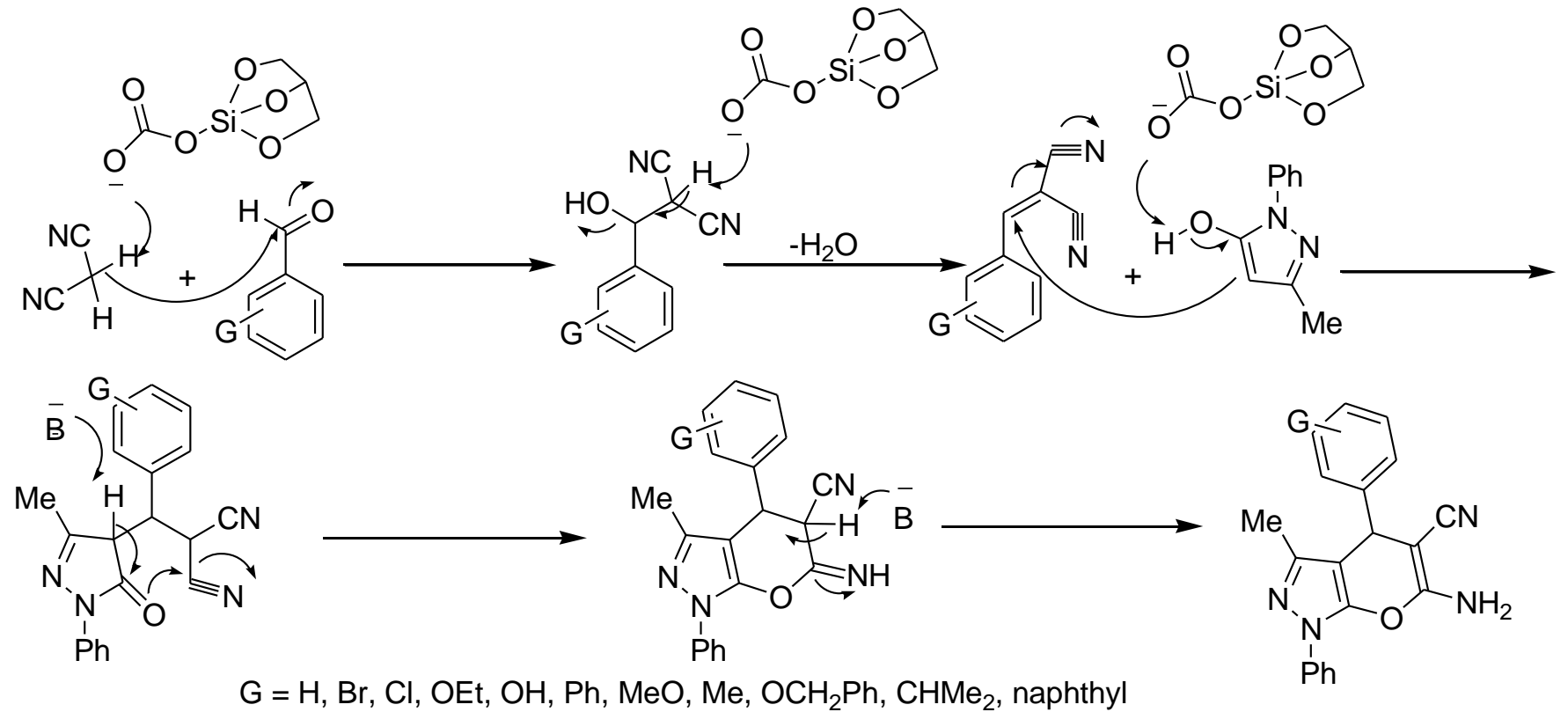

Scheme 37. Mechanism.

Brønsted acidic task-specific ionic liquids, have a dual action as solvent and catalyst and possess tunable polarities, high thermal stability, and are immiscibility with a number of organic solvents, negligible vapor pressure, and are recyclable. ${ }^{48,49}$ Khurana and Chaudhary used 1-butyl-3-methylimidazolium hydroxide, for the synthesis of pyrano[2,3-c]pyrazoles and $4 \mathrm{H}$-pyran derivatives. ${ }^{50}$ When pyrazolone, arylaldehydes and malononitrile are mixed in $20 \mathrm{~mol} \%$ of [bmim]OH, pyranopyrazoles are produced, while, pyran derivatives were obtained by replacing pyrazolone with ethyl acetoacetate or acetylacetone (Scheme 38). In the synthesis of pyranopyrazoles, the nature of substituent has very little effect on the reaction rate and yield of the products while, aryl aldehydes with electron withdrawing groups reacted faster than those with electron donating groups to form pyran derivatives. Furthermore, other ionic liquids such as [bmim] $\mathrm{Br}$ and $\left[\mathrm{bmim}^{\mathrm{B}} \mathrm{BF}_{4}\right.$ were also applied to pyran synthesis, but failed.<smiles>[R7]C(=O)C1=C(C)OC(N)=C(C#N)C1Br</smiles>

27

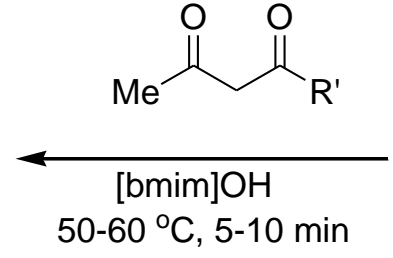

$50-60{ }^{\circ} \mathrm{C}, 5-10 \mathrm{~min}$<smiles>N#CC[C+]C(=O)[Hg]</smiles>

14

yield $87-92 \%$

$\mathrm{R}^{\prime}=\mathrm{Me}, \mathrm{OEt}$

$\mathrm{R}=\mathrm{Me}$

$\mathrm{Ar}=\mathrm{Ph}, 4-\mathrm{Cl}-\mathrm{Ph}, 4-\mathrm{Me}-\mathrm{Ph}, 4-\mathrm{MeO}-\mathrm{Ph}, 4-\mathrm{NO}_{2}-\mathrm{Ph}, 3-\mathrm{Br}-\mathrm{Ph}, 4-\mathrm{F}-\mathrm{Ph}, 4-\mathrm{HO}-\mathrm{Ph}, 3-\mathrm{NO}_{2}-\mathrm{Ph}, 2-\mathrm{MeO}-\mathrm{Ph}$, 4-Br-Ph, 2-Cl-Ph, 2- $\mathrm{NO}_{2}-\mathrm{Ph}, 4-\mathrm{HO}-\mathrm{Ph}, 4-\mathrm{NMe}_{2}-\mathrm{Ph}, 3,4,5$-trimethoxy-Ph, 2-furanyl, 1-naphthyl,

\section{Scheme 38}

Niknam and Piran prepared recyclable silica-grafted $\mathrm{N}$-propylimidazolium hydrogen sulphate ([Sipim] $\mathrm{HSO}_{4}$ ) and heated it with reactants at $110{ }^{\circ} \mathrm{C}$ under solvent-free conditions to obtain pyranopyrazoles $15 .^{51}$ When pyrazolone was replaced with 4-hydroxycoumarin (115) and heated at $100{ }^{\circ} \mathrm{C}, 3,4$-dihydropyrano[c]chromenes 
were produced 116 (Scheme 39). Thus reaction is applicable for variety of aldehydes as well lactones such as coumarin. It was also observed that the catalyst is recyclable and could be used four times without any significant loss in activity.<smiles>N#CC1=C(N)Oc2c(c(=O)oc3ccccc23)C1Br</smiles>

yield $89-95 \%$<smiles>O=c1cc(O)c2ccccc2o1</smiles>

115

([Sipim $\left.] \mathrm{HSO}_{4}\right)$ solvent free, $100^{\circ} \mathrm{C}$ $\mathrm{R}^{1}=\mathrm{Ph}$ $R^{2}=M e$<smiles>N#CC[C+]C=O</smiles>

91
14 solvent free, $110^{\circ} \mathrm{C}$

$\mathrm{Ar}=\mathrm{Ph}$, 4-Cl-Ph, 4-Br-Ph, 4-F-Ph, 3- $\mathrm{NO}_{2}-\mathrm{Ph}$, 4- $\mathrm{HO}-\mathrm{Ph}$,

\section{Scheme 39}

Similarly, Heravi and co-workers used Preyssler type heteropolyacid $\mathrm{H}_{14}\left[\mathrm{NaP}_{5} \mathrm{~W}_{30} \mathrm{O}_{110}\right]$ under solvent free conditions, but this failed to produce any products. ${ }^{52}$ However when used in water/ethanol mixture, excellent results were obtained, probably due to two reasons $(a)$ the first stage of the reaction includes Knoevenagel condensation, which is faster in water, and $(b)$ the PKa of HPA depends on the solvent. Reaction conditions found effective for pyrazolone, barbituric acid, aldehydes having electron-donating and electron withdrawing substituent but, did not work for ethyl cyanoacetate, diethyl malonate, ethyl benzoylacetate, ethyl acetoacetate and acetophenone (Scheme 40).

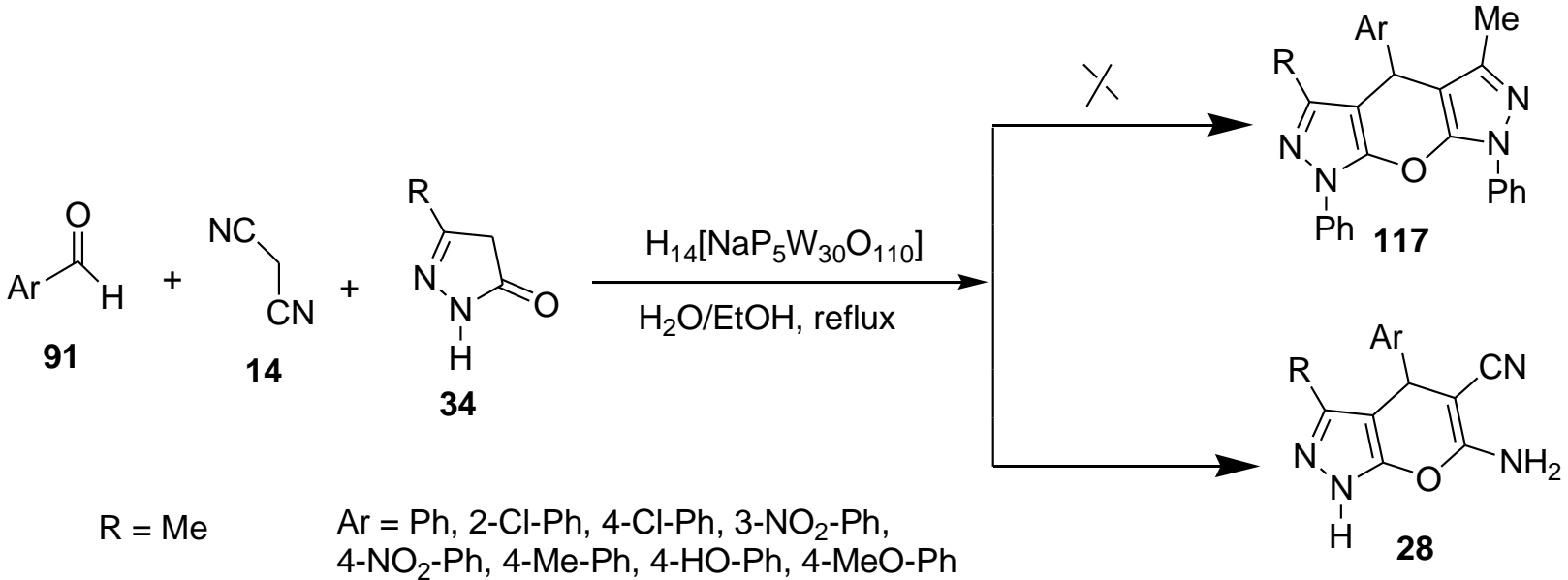

yield $85-95 \%$

\section{Scheme 40}

Mandour and co-workers treated 3-amino-5-pyrazolone (60) with $\mathrm{N}$-substituted indole-3-carboxaldehydes (118) under acidic conditions to form substituted pyrazol-5-ones 119, which were refluxed with $p$ fluoro/chlorobenzylidenemalononitrile to form 3-[( $N$-substituted indol-3-yl)methyleneamino]-6-amino-4-arylpyrano[2,3-c]pyrazol-5-carbonitrile (120) (Scheme 41). ${ }^{53}$ 


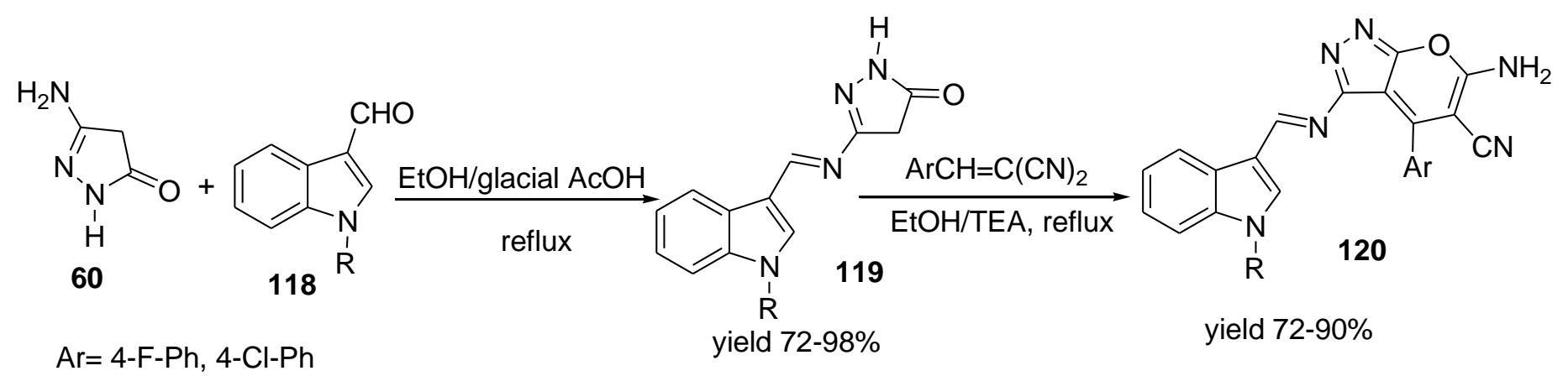

$\mathrm{R}=\mathrm{H}, \mathrm{Et}, \mathrm{COPh}, \mathrm{COPh}-4-\mathrm{Cl}, \mathrm{SO}_{2} \mathrm{Ph}, \mathrm{SO}_{2} \mathrm{Ph}-4-\mathrm{Br}, \mathrm{COPh}-2-\mathrm{Cl}$

\section{Scheme 41}

In addition, indole-aldehydes (118) also reacted under basic conditions to form 4-indolepyrano[2,3c]pyrazoles (123) by two sequence. ${ }^{53}$

(a) Aminopyrazolones (60) and indolecarboxaldehydes (118) refluxed in ethanol containing triethylamine to form intermediate 121, which further reacted with malononitrile to form pyrano[2,3-c]pyrazoles (123).

(b) Under the same reaction conditions, indolecarboxaldehydes (118) refluxed with malononitrile (14) to form intermediate 122, which reacted with aminopyrazolone (60) to form pyranopyrazoles 123 (Scheme 42 ). The synthesized compounds were tested for biological activities where all exhibited remarkable antiinflammatory, analgesic and anticonvulsant activities and most of the analogues found potential as antimicrobial agent. Some compounds showed anticonvulsant potency more than both anti-inflammatory and analgesic activities. It was also observed that presence of halo atoms increased biological action.

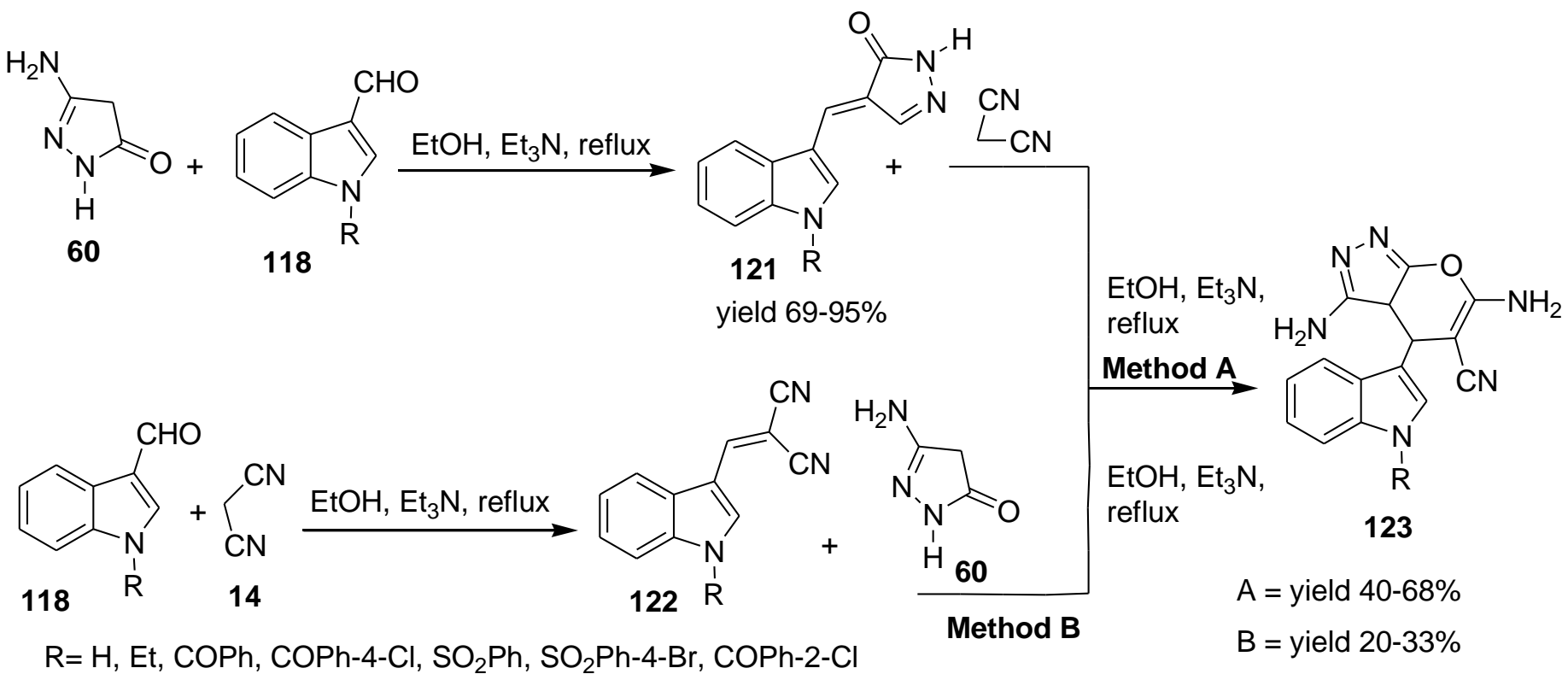

\section{Scheme 42}

Rodinovskaya and co-workers used 4-(3-cyanopyridin-2-yl-thio)acetoacetic ester (124) to synthesize pyridine based pyrazolone 125 which further reacted with benzylidemalononitriles (26) (path A) or with aldehydes and malononitrile in ethanol containing triethylamine (path B) to form Michael adduct 126 as an 
intermediate, which finally cyclized to afford pyranopyrazole 127 containing methylthiopyridine substituents at 2-position (Scheme 43). ${ }^{54}$
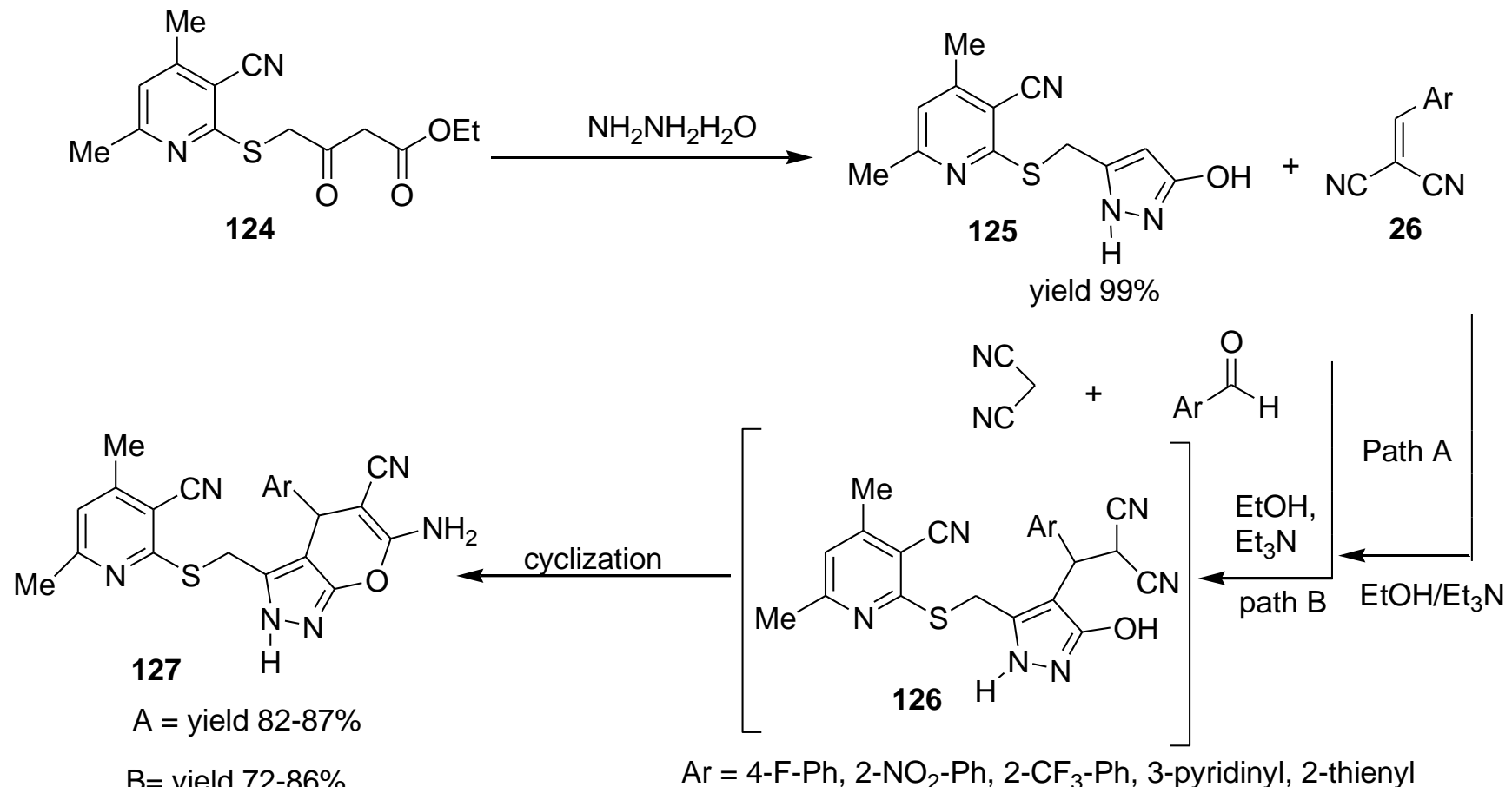

\section{Scheme 43}

Similarly, alkylated morpholinium 1,4-dihydropyridine-2-thiolate (128) with ethyl 4-chloroacetoacetate (129) yielded 2-(3-ethoxycarbonyl-2-oxopropylthio)-1,4-dihydropyridine (130) which was treated with hydrazine hydrate to form 2-(pyrazol-5-ylmethylthio)-1,4-dihydropyridine (131) that was further refluxed with 4-fluorobenzylidene malononitrile (132) to form highly substituted pyranopyrazoles $133 .{ }^{54} \mathrm{X}$-Ray crystallography revealed its tautomeric form with the hydrogen attached to second nitrogen instead of first of the pyrazole ring (Scheme 44).

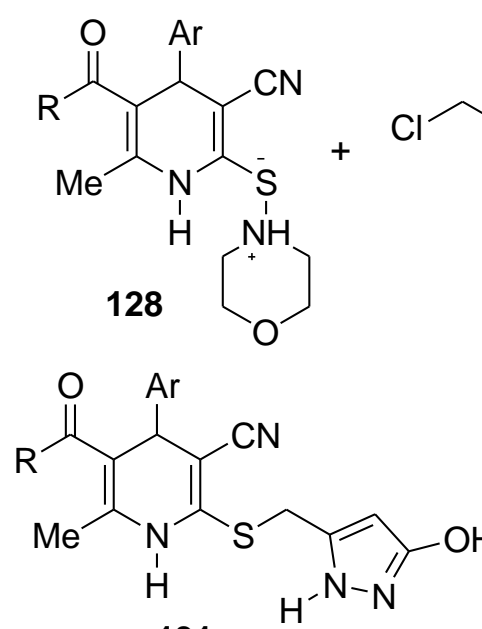

131
129<smiles>N#CC(C#N)=Cc1ccc(F)cc1</smiles>

132<smiles>[R]C(=O)C1=C(C)NC(SCC(=O)CC(=O)OCC)=C(C#N)C1[AlH2]</smiles>
yield $67 \%$<smiles>[R]C(=O)C1=C(C)NC(SCc2[nH]nc3c2C(c2ccc(F)cc2)C(C#N)=C(N)O3)=C(C#N)C1Br</smiles>

133 yield $69-97 \%$ $\mathrm{R}=\mathrm{NH}-\mathrm{Ph}, \mathrm{OEt}$ $\mathrm{Ar}=3$-pyridinyl, 4- $\mathrm{MeO}_{2} \mathrm{CPh}$ yield $49-65 \%$

\section{Scheme 44}


Kathrotiya and co-workers carried out Vilsmeier-Haack reaction on indole 134 to form 2-(4un/substitutedphenyl)- $1 \mathrm{H}$-indole-3-carboxaldehydes (135) which reacted with malononitrile and pyrazol-5one to form indole 2-substituted pyranopyrazoles 136 (Scheme 45$).{ }^{55}$ The reaction mechanism was proposed to involve Knoevenagel condensation between aldehydes and malononitrile with loss of water, followed by Michael addition and cyclization to form pyranopyrazoles as mentioned in Scheme 31. These were tested for antibacterial activity against eight human pathogens. Some analogues were found more active than standard drugs.

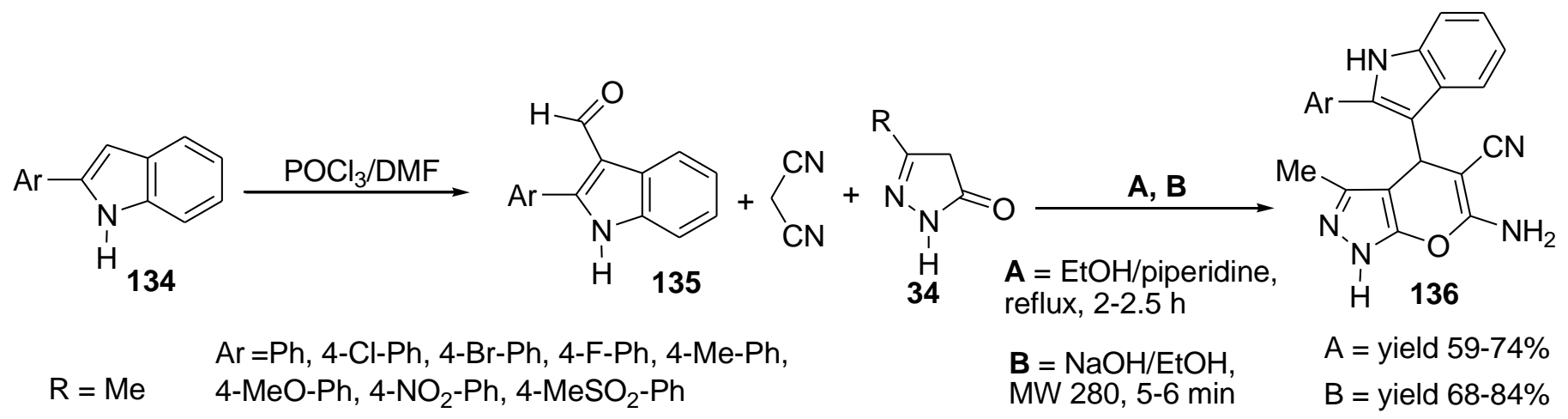

\section{Scheme 45}

Enders and co-workers tested different secondary amines as catalysts for reaction of $\alpha, \beta$-unsaturated aldehydes 137 and Wittig reagent 138 to prepare enantioselective tetrahydropyranopyrazoles 139 where, MacMillan imidazolidinone showed excellent result in chloroform/toluene with a small amount of methanol (Scheme 46). ${ }^{56}$ One pot reaction gave better yields and enantioselectivity than a two-step synthesis. Furthermore, NOESY experiments revealed that the major diastereomer shows trans configuration.

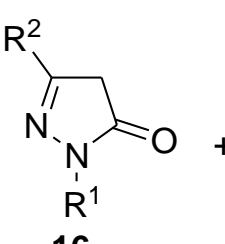

16<smiles>O=CC=CC=[18O]</smiles>

137<smiles>[R]C(=O)C=[PbH2]</smiles>

138

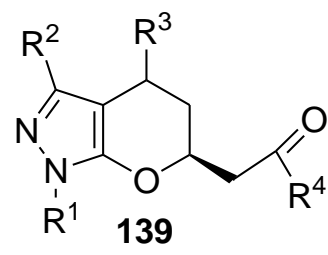

yield $73-88 \%$

$\mathrm{R}^{1}=\mathrm{Me}, \mathrm{Ph} \quad \mathrm{R}^{2}=\mathrm{CF}_{3} \quad \mathrm{R}^{3}=\mathrm{Me}, \mathrm{Et}, \mathrm{Bu}, \mathrm{pr}^{\mathrm{n}}$, pri, $\mathrm{Ph}, \mathrm{CH}_{2} \mathrm{OTIPS}, \mathrm{CH}_{2} \mathrm{OBz} \quad \mathrm{R}^{4}=\mathrm{Ph}, \mathrm{OEt}$, 4-Br-Ph, 3-MeO-Ph

\section{Scheme 46}

Reaction is believed to be catalyzed by secondary amine to form Michael intermediate $\mathbf{1 4 0}$ which cyclized to form 6-hydroxy pyranopyrazoles 141, followed by Wittig reagent initiated ring-opening 142 and finally oxaMichael domino reaction to give final product 139 (Scheme 47). ${ }^{56}$ Wittig reaction with electron-rich or neutral substituents of phosphoranes showed greater enantioselectivity and yields as compare to slightly electrondeficient phosphoranes. Structure of compound was confirmed by X-ray studies. 


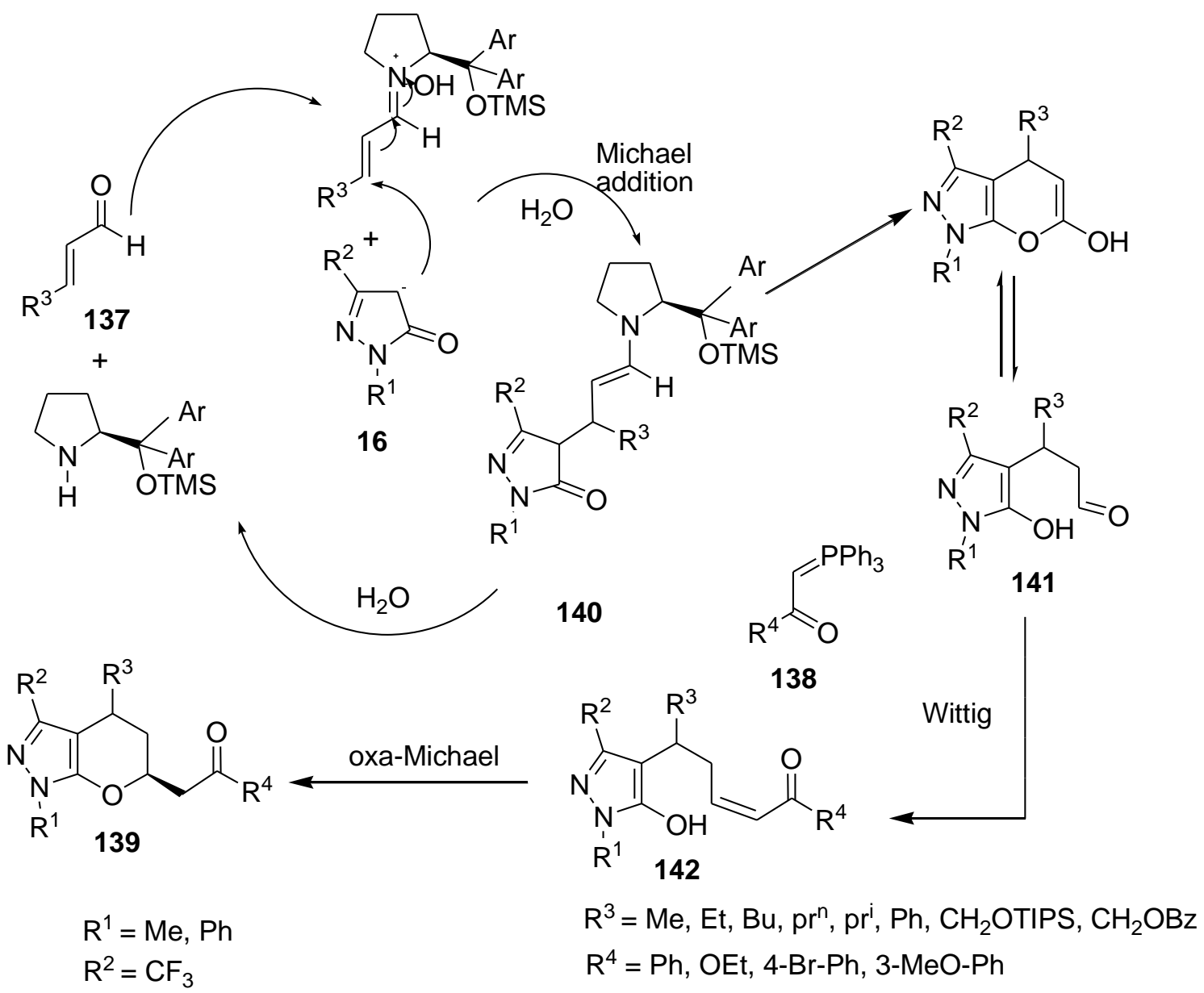

Scheme 47. Mechanism.

Shestopalov et al. replaced aldehydes with substituted piperidin-4-ones (143) to prepare spiro-4(piperidine-4')pyrano[2,3-c]pyrazole (144) by following methods

(i) Refluxing for $10 \mathrm{~min}$ in the presence of triethylamine

(ii) Stirring at room temperature without base for $12 \mathrm{~h}$

(iii) Electrolysis in acetonitrile using $40 \mathrm{~mL}$ of $0.1 \mathrm{M} \mathrm{Bu}{ }_{4} \mathrm{NBr}$ as catholyte gives pyranopyrazoles 144 regioselectively (Scheme 48$). .^{57}$<smiles>[R]C1CN([18F])C([R])CC1=O</smiles>

143

$\mathbf{A}=\mathrm{Et}_{3} \mathrm{~N}, \mathrm{EtOH}$, reflux $10 \mathrm{~min}$

$\mathbf{B}=\mathrm{Et}_{3} \mathrm{~N}, \mathrm{EtOH}$, stirr $12 \mathrm{~h}$

C = electrolysis, $\mathrm{MeCN}, \mathrm{Bu}_{4} \mathrm{NBr}$

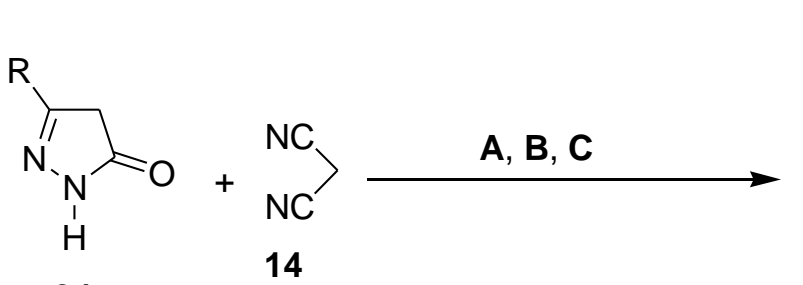

34<smiles>[R]c1c2c(nn1[2H])OC(N)=C(C#N)C21CC([R])N([R])CC1[R]</smiles>

144

$\mathrm{R}=\mathrm{Me}, \mathrm{Et}, \mathrm{CH}_{2} \mathrm{OMe}, \mathrm{Ph}, \mathrm{pr}^{\mathrm{n}}$

$\mathrm{R}^{1}=\mathrm{H}, \mathrm{Me}, \mathrm{Et}, \mathrm{CH}_{2} \mathrm{CH}_{2} \mathrm{Ph}, \mathrm{COMe}, \mathrm{CO}_{2} \mathrm{Et}$

yield $51-94 \%$

$\mathrm{R}^{2}=\mathrm{H}, \mathrm{Me} \quad \mathrm{R}^{3}=\mathrm{H}, \mathrm{Me}$

\section{Scheme 48}


It was proposed that the reaction proceeds by two plausible pathways. ${ }^{57}$

(a) Initial reaction of malononitrile and ketone yields alkene $\mathbf{1 4 5}$ which reacts further with pyrazolone to give Michael adduct 146, which cyclises to form pyranopyrazole 144 (Path A)

(b) Ketone and pyrazolone react to form intermediate 147 which reacts with malonitrile (Path B) (Scheme 49)

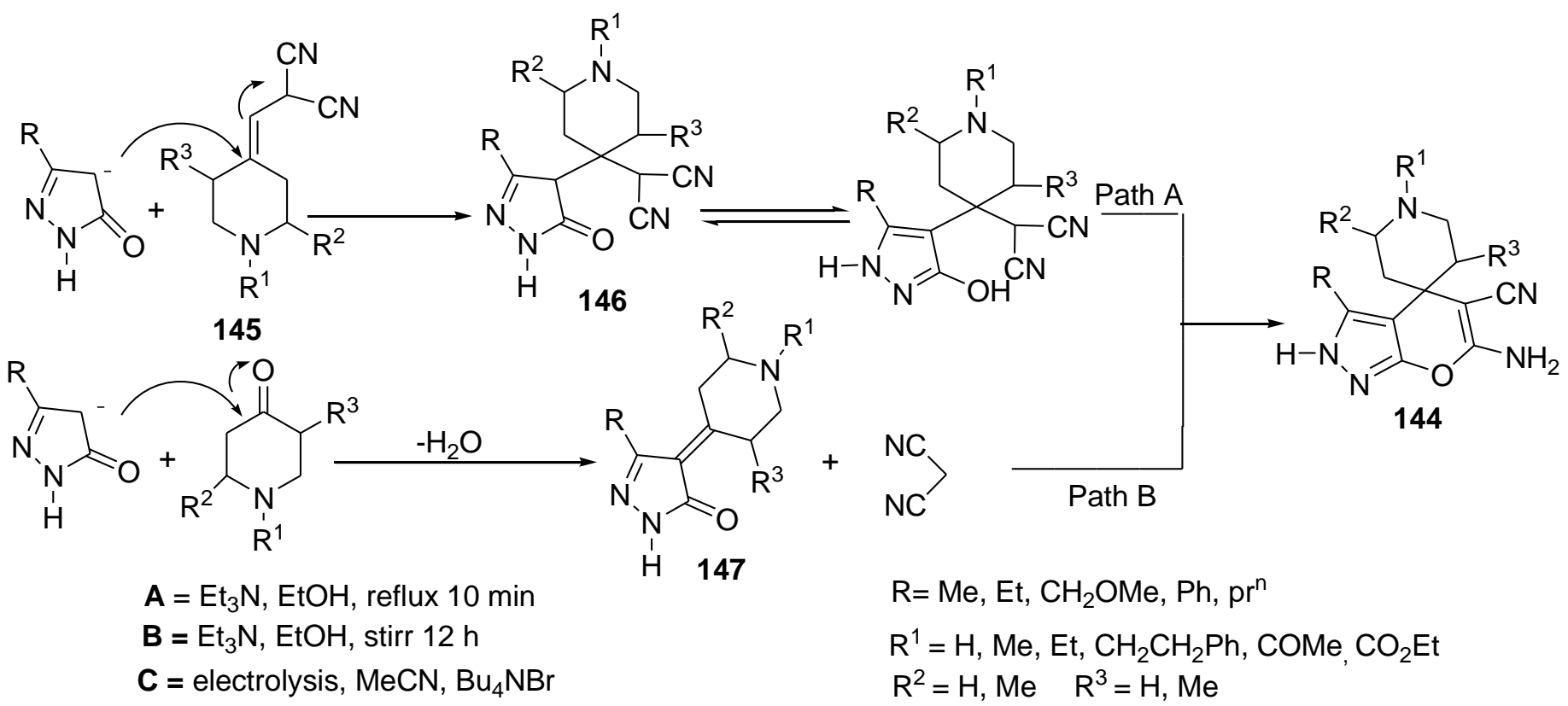

\section{Scheme 49}

Malononitrile and ketone were treated to obtain nitrile 145 which being reactive and unstable dimerized to 148 , which supported Pathway B. ${ }^{57}$ Similarly, reaction with sterically hindered ketone named, adamantan-2one, yielded a Michael adduct 149 which did not undergo further reaction (Figure 9).
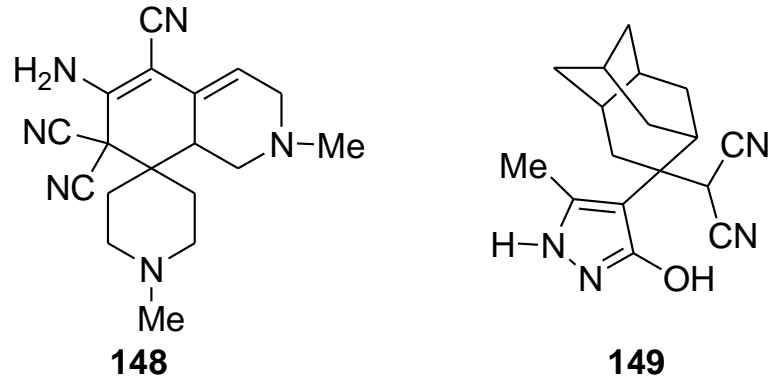

\section{Figure 9}

Al-Thebeiti carried out a solvent-free synthesis by fusing pyrazolone and cyclic ketone $\mathbf{1 5 0}$ in the presence of anhydrous sodium acetate at $200{ }^{\circ} \mathrm{C}$ to get intermediate 151 which were refluxed with malononitrile to obtain spiropyrano[2,3-c]pyrazoles (152) and derivatized further to oxo- and amino- pyrimidines using various reagents. ${ }^{58}$ Some of the synthesized analogues exhibited moderate antimicrobial activity against Escherichia coli and Staphylococcus aureus (Scheme 50). 


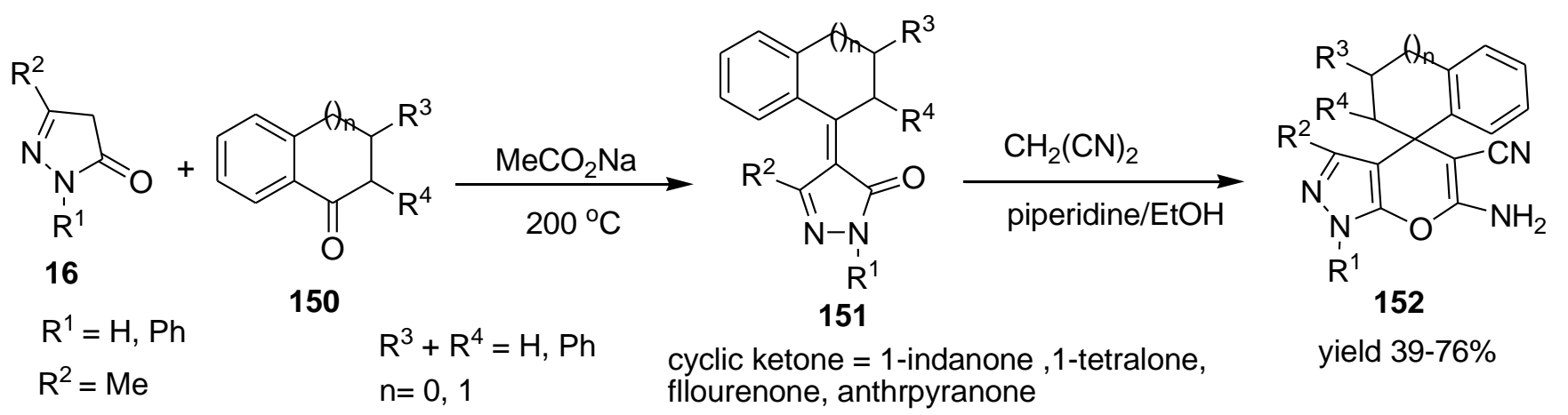

\section{Scheme 50}

Riad and co-workers reacted acetoacetanilide (153) and $\alpha$-cyanocinnamonitrile derivatives to produce intermediate 154 which when either treated with hydrazine hydrate to form pyrano[2,3-c]pyrazole (28) (Scheme 51) or cyclized under acidic conditions gave pyran derivatives. ${ }^{59}$ It was also observed that these pyranopyrazoles could be converted easily to pyrazolopyridines in acetic acid and ammonium acetete. These compounds showed moderate inhibition effect on bacteria.<smiles>[R]C(=O)CC(=O)Nc1ccccc1</smiles>

$\mathrm{Ar}=\mathrm{Ph}$, 4-MeO-Ph, 4-Me-Ph, 4-Cl-Ph, 4- $\mathrm{NO}_{2}-\mathrm{Ph}$<smiles>[R]C(=O)C(C(=O)Nc1ccccc1)C([Al])C(C#N)C(C)(C)C</smiles>

$\mathrm{R}=\mathrm{Me}$<smiles></smiles>

28

\section{Scheme 51}

In addition to these ketones, un/substituted isatin (155) has been widely used for synthesis of spiro-2oxindole-pyranopyrazoles. Redkin and co-workers treated isatin, with a suitable $\mathrm{CH}$ acid (malononitrile/cyanoacetic ester) and pyrazolones via a one pot (Scheme $52 \mathrm{~A}$ ) or two step method involving reaction of isatin and $\mathrm{CH}$ acid to form intermediate $\mathbf{1 5 6}$ which further reacts with pyrazolone to form pyranopyrazoles 157 (Scheme $52 \mathrm{~B}$ ). ${ }^{60}$ It was assumed that the formation of the Michael adduct is common in both methods which cyclized regioselectively to pyrano[2,3-c]pyrazol bearing spiro-2-oxindole derivatives. Similarly, Dandia and co-workers ground $\mathrm{N}$-unsubstituted isatin $\mathbf{1 5 5}$ and malononitrile in agate mortar or subjected to microwave irradiation at $640 \mathrm{~W}$ to get intermediate 156 (Scheme $52 \mathrm{C}$ ) which adsorbed on neutral alumina using methanol and treated with pyrazolone to get pyranopyrazoles $157^{61}$ (Scheme $52 \mathrm{D}$ ). 
<smiles>[R]C1=NN([R])C(=O)C1</smiles><smiles>[X]CC[N+]=c1c(=O)c(=O)c2cc([R])ccc12</smiles>

Method A<smiles>[Z8]c1ccc2c(c1)C(=O)C(=[O+]C([Y])C#N)N2[R9]</smiles>

155<smiles>[X]C(C#N)=C1C(=O)N([R])c2ccc([Z7])cc21</smiles><smiles>[R]C1=NN([R7])C(=O)C1</smiles>

B',D<smiles>[Z8]c1ccc2c(c1)N([R7])C(=O)C21C(=O)C(N)=C(C)c2c1c([R])nn2[R7]</smiles>

156

\begin{tabular}{|c|c|c|c|c|c|c|c|}
\hline Method & $\mathbf{R}^{\mathbf{1}}$ & $\mathbf{R}^{\mathbf{2}}$ & $\mathbf{R}^{\mathbf{3}}$ & $\mathbf{R}^{\mathbf{4}}$ & $\mathbf{X}$ & \multicolumn{1}{c|}{ Condition } & Yield \\
\hline $\mathbf{A}$ & $\mathrm{H}$ & $\mathrm{Me}$ & $\begin{array}{l}\mathrm{H}, \mathrm{Me}, \\
\mathrm{Bu}\end{array}$ & $\mathrm{H}, \mathrm{Me}$ & $\mathrm{CN}, \mathrm{CO}_{2} \mathrm{Et}$ & $\begin{array}{l}\text { EtOH, TEA, } \\
\text { heat if X= CN, } \\
\text { Reflux 2 } \mathrm{h}, \text { if } \mathrm{X}=\mathrm{COOEt}\end{array}$ & $55-74 \%$ \\
\hline $\mathbf{B}$ & $\mathrm{H}$ & $\mathrm{Me}$ & $\begin{array}{l}\mathrm{H}, \mathrm{Me}, \\
\mathrm{Bu}\end{array}$ & $\mathrm{H}, \mathrm{Me}$ & $\mathrm{CN}, \mathrm{CO}_{2} \mathrm{Et}$ & $\begin{array}{l}\text { EtOH, TEA, rt/ heat } \\
\mathbf{B}^{\prime}=\mathrm{EtOH}, \mathrm{TEA}, \\
\text { reflux 1-2 } \mathrm{h}\end{array}$ & $43-68 \%$ \\
\hline $\mathbf{C}$ & $\begin{array}{l}\mathrm{Ph}, 5-\mathrm{Cl}-\mathrm{Ph}, \\
5-\mathrm{NO}_{2}-\mathrm{Ph}, \\
5,7-\text { dimethyl-Ph }\end{array}$ & $\mathrm{Me}$ & $\mathrm{H}$ & $\mathrm{H}$ & $\mathrm{CN}$ & $\begin{array}{l}\text { solid satate ground or } \\
\text { MW, 640 W, 30 sec. }\end{array}$ & $60-98 \%$ \\
\hline $\mathbf{D}$ & $\begin{array}{l}\mathrm{Ph}, 5-\mathrm{Cl}-\mathrm{Ph}, \\
5-\mathrm{NO2-Ph,} \\
5,7-\text { dimethyl-Ph }\end{array}$ & $\mathrm{Me}$ & $\mathrm{H}$ & $\mathrm{H}$ & $\mathrm{CN}$ & $\begin{array}{l}\text { alumina/ MeOH, MW, } \\
640 \mathrm{~W}\end{array}$ & $90-94 \%$ \\
\hline
\end{tabular}

\section{Scheme 52}

Poomathi and co-workers developed a one-pot regioselective synthesis of spiroxindoles using isatins (155), pyrazoles and (E-)-N-methyl-1-(methylthio)-2-nitroethenamine (NMSM) (158) under the catalytic action of Lewis acid such as $\mathrm{SnCl}_{2} \cdot 2 \mathrm{H}_{2} \mathrm{O}$, PTSA $\cdot \mathrm{H}_{2} \mathrm{O}, \mathrm{FeCl}_{3}, \operatorname{In}(\mathrm{OTf})_{3}, \mathrm{AlCl}_{3}$, and $\mathrm{BiCl}_{3}$ in $\mathrm{MeOH}$, EtOH and $\mathrm{MeCN}$ using different mol\% quantity where $20 \mathrm{~mol} \%$ of $\mathrm{InCl}_{3}$ in ethanol afforded highest yield without any need of column chromatographic purification (Scheme 53). ${ }^{62}$

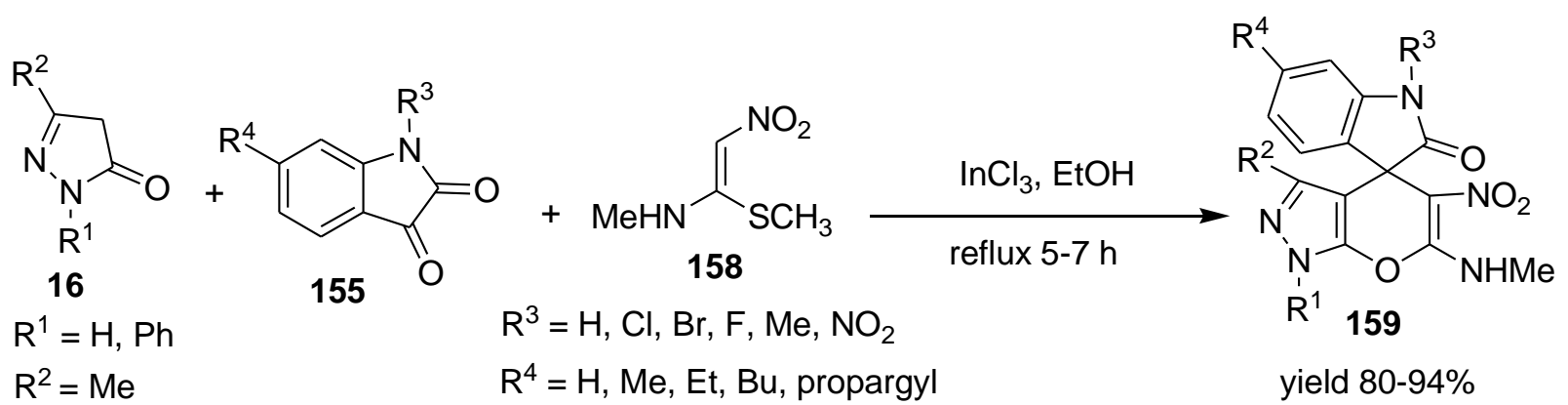

\section{Scheme 53}


The reaction mechanism was proposed to involve indium chloride initiated Knoevenagel condensation of pyrazolone and isatin producing an adduct 161, which acts as Michael acceptor and readily underwent Michael-type addition with NMSM to form an open chain intermediate $162 .{ }^{62}$ The intermediate has the possibility to follow path $\mathrm{A}$ (O-cyclization) or path $\mathrm{B}$ ( $\mathrm{N}$-cyclization) to give product 166 , but only pyranopyrazoles 159 were obtained via elimination of MeSH. X-Ray studies of 7-chloro-3-(3-methyl-6(methylamino)-5-nitro-1-phenyl-1,4-dihydropyrano[2,3-c]pyrazol-4-yl)indolin-2-one additionally also favored O-cyclization (Scheme 54).

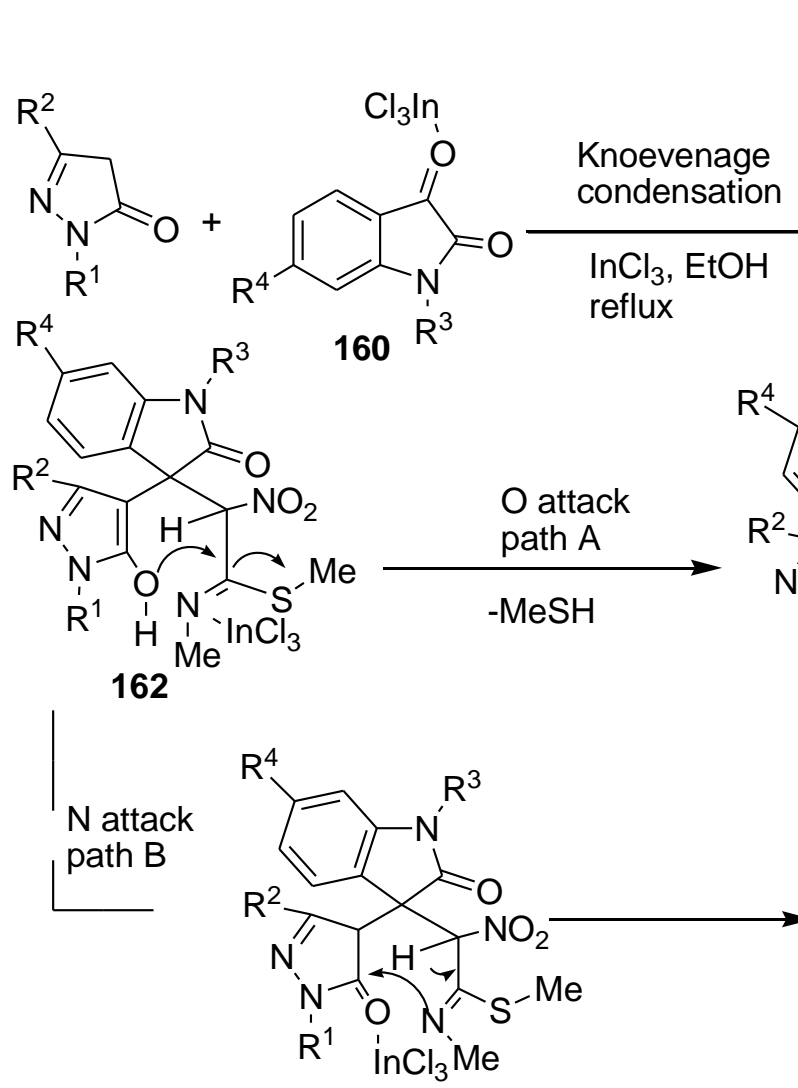

164
161
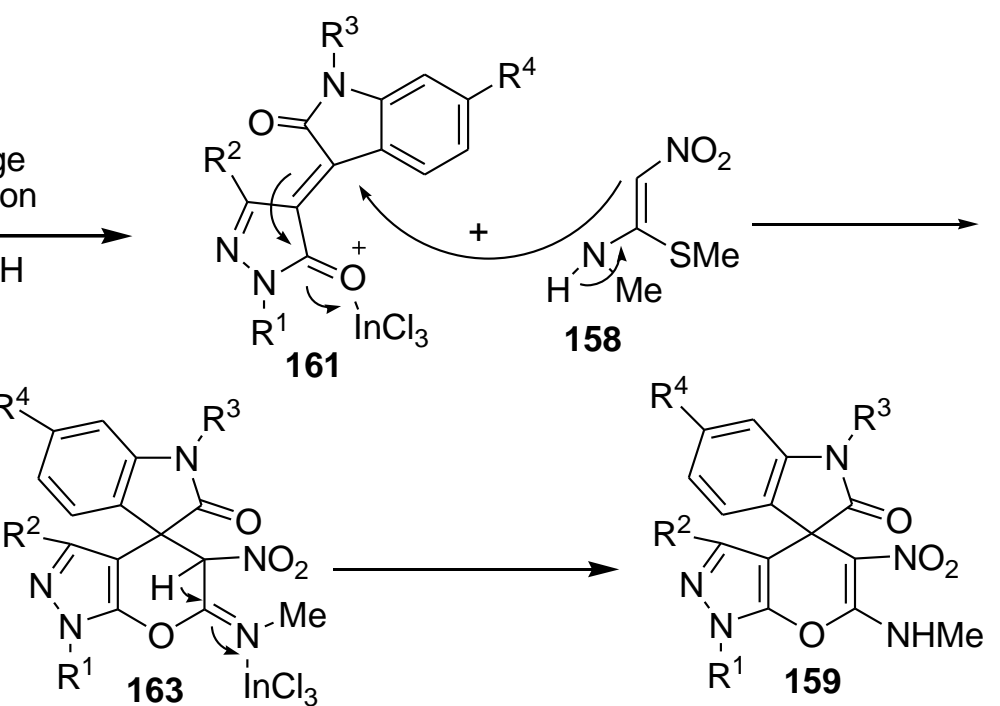

$$
\mathrm{R}^{1}=\mathrm{H}, \mathrm{Ph} \quad \mathrm{R}^{2}=\mathrm{Me} \quad \mathrm{R}^{3}=\mathrm{H}, \mathrm{Cl}, \mathrm{Br}, \mathrm{F}, \mathrm{Me}, \mathrm{NO}_{2} \quad \mathrm{R}^{4}=\mathrm{H}, \mathrm{Me}, \mathrm{Et}, \mathrm{Bu}, \text { propargyl }
$$

Scheme 54. Mechanism.

Shanthi and co-workers also used indium (III) chloride as catalyst either in acetonitrile at reflux temperature or under microwave irradiation adsorbed on silica gel. ${ }^{63}$ Carbonyl compounds as pyrazolone, indenoquinoxaline, naphthol, 4-hydroxycoumarin or $3 \mathrm{H}$-chromene-2,4-dione reacted with malononitrile/ethyl cyanoacetate and isatin under these reaction conditions to prepare spirooxindoles and spiroindenoquinoxaline 167-169 (Figure 10). Reaction conditions did not work for aniline replacing naphthol and enone.

Mandha et al. carried out a non-catalytic synthesis in water/ethanol mixture using various carbonyl compounds such as aldehydes 91, isophthalaldehyde (170), indole-2,3-dione (49), and 9-fluorenone (171). ${ }^{64}$ The reaction mechanism is believed to involve Knoevenagel condensation between the carbonyl compounds and malononitrile to form various benzylidemalononitrile as intermediates 26, 172-174, which underwent Michael addition with pyrazolin-5-one, followed by intramolecular cyclization to form polyfunctional 
pyranopyrazoles $\mathbf{1 5}, \mathbf{1 7 5 - 1 7 7}$. These were tested for antibacterial, anti-inflammatory and cytotoxicity (Scheme 55). X-Ray studies confirmed the $2-H$ tautomeric form.<smiles>[X]C1=C(N)Oc2c(c(C)nn2-c2ccccc2)C12C(=O)N([R])c1ccccc12</smiles>

167

yield $90-92 \%$

$\mathrm{R}=\mathrm{H}, \mathrm{Me}$<smiles>Cc1nn(-c2ccccc2)c2c1C1(C(C#N)=C(N)Oc3ccccc31)c1nc3ccccc3nc1-2</smiles>

168

$\mathrm{X}=\mathrm{CN}, \mathrm{CO}_{2} \mathrm{Et}$<smiles>[R]Cc1c([R])c([R])c([R1])c2c1C1(C(=O)N([R])c3ccccc31)C([X])=C(N)O2</smiles>

yield $88 \%$

$\mathrm{R}^{1}+\mathrm{R}^{2}=\mathrm{Ph}, \mathrm{R}^{3}+\mathrm{R}^{4}=\mathrm{H}$

$R^{1}+R^{2}=H, R^{3}+R^{4}=P h$

Figure 10<smiles>[R]c1nn([R1])c2c1C(c1ccc(C3C(C#N)=C(N)Oc4c3c([R7])nn4[Y10]([H])([H])C)cc1)C(C)=C(C)O2</smiles>

174<smiles>[R]C1=NNC(=O)C1</smiles>

$\mathrm{R}^{1}$

16<smiles>[R]C1=NN([R7](C)C)C(=O)C1</smiles>

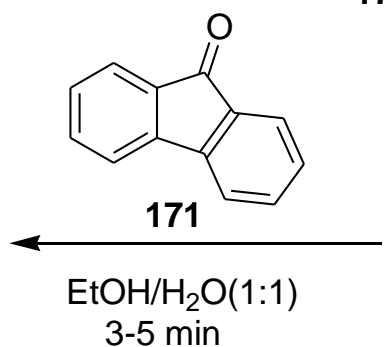

3-5 min

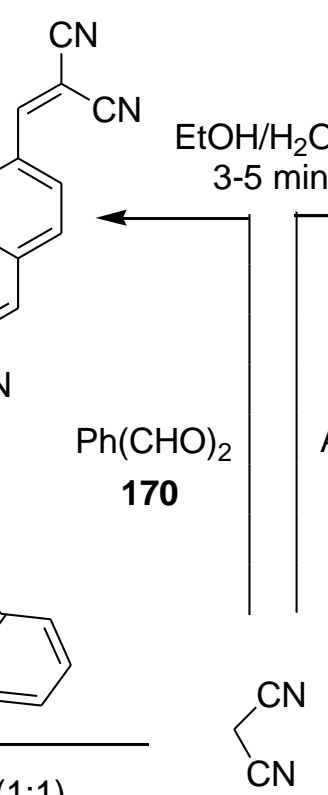

$\mathrm{CN}$

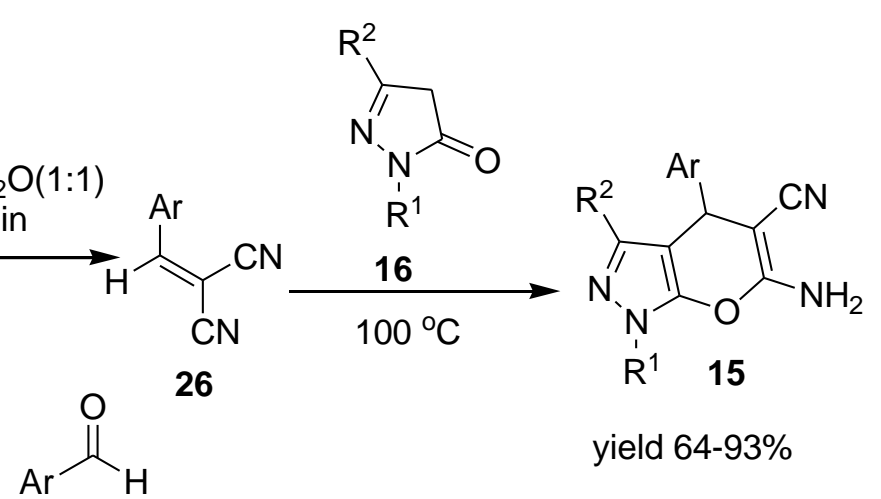

91<smiles>CCO[AsH3]</smiles><smiles>N#CC(C#N)=C1C(=O)Nc2ccccc21</smiles>

173

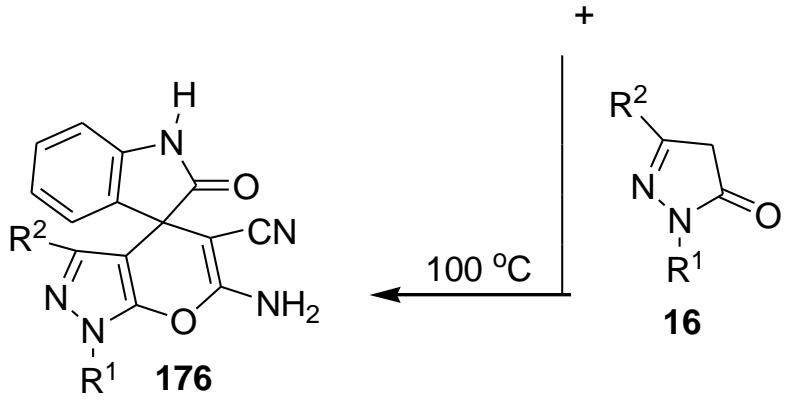

yield $81-86 \%$ yield $80-89 \%$
$\mathrm{R}^{1}=\mathrm{H}, \mathrm{Ph}$
$\mathrm{Ar}=\mathrm{Ph}$, 4-Br-Ph, 3-HO-Ph, 4-Me-Ph, 4-HO-Ph, 4-MeO-Ph, 4- $\mathrm{NO}_{2}-\mathrm{Ph}$,
$\mathrm{R}^{2}=\mathrm{Me}$
3- $\mathrm{C}_{6} \mathrm{H}_{5} \mathrm{O}-\mathrm{Ph}$, 3-pyridinyl, 2-thienyl, 4- $\mathrm{C}_{11} \mathrm{H}_{5} \mathrm{Cl}_{3} \mathrm{NO}$, 3- $\mathrm{C}_{11} \mathrm{H}_{5} \mathrm{Cl}_{3} \mathrm{NO}, \mathrm{C}_{6} \mathrm{~F}_{5}$

Scheme 55 
Elinson and coworkers electrolyzed an ethanolic solution of isatin, malononitrile, pyrazolone and sodium bromide in an undivided cell having a magnetic stirrer. ${ }^{65}$ Reaction was found to be successful after passing $0.04 \mathrm{~F} / \mathrm{mol}$ quantity of electricity at different densities but, $2 \mathrm{~mA} / \mathrm{cm}^{2}$ was found optimal to obtain excellent yields of spiro[indole-3,4-pyrano[2,3-c]pyrazoles] (157) (Scheme 56).

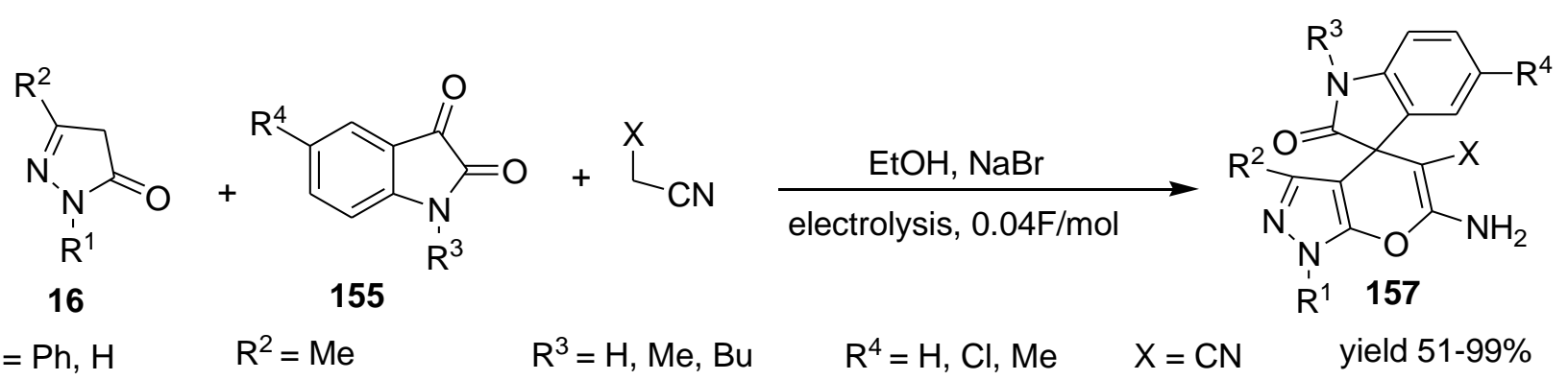

\section{Scheme 56}

The reaction mechanism was proposed to involve ethoxide ion catalyzed Knoevenagel condensation of malononitrile and isatin with elimination of hydroxide ion to give electron-deficient Knoevenagel adduct 156, followed by Michael addition of pyrazolone to form Michael adduct $\mathbf{1 7 9}$ and finally cyclization to form pyran ring system (Scheme 57). ${ }^{65}$
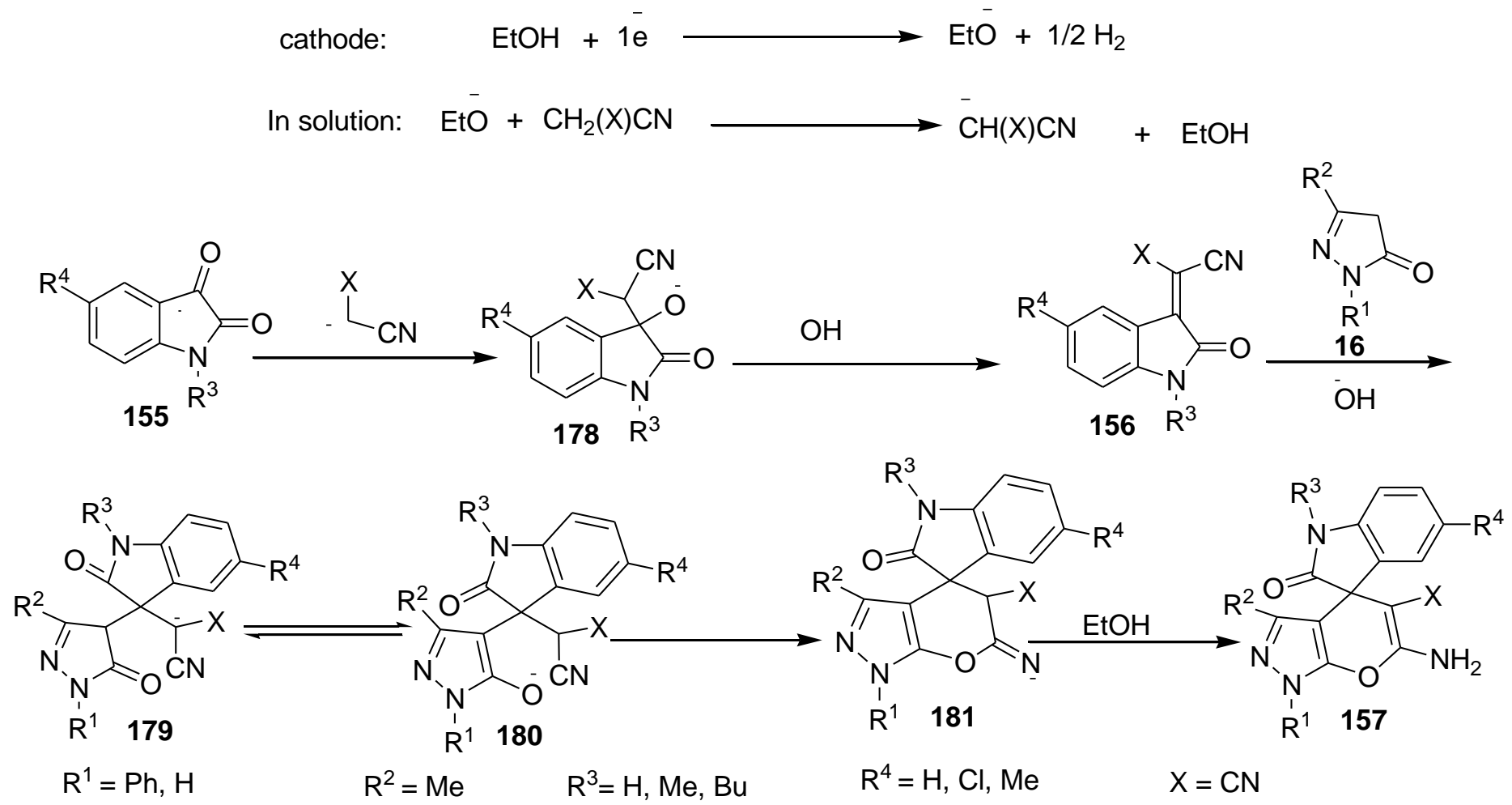

\section{Scheme 57}

Litvinov and Shestopalov reacted aromatic aldehydes, malononitrile with the corresponding nucleophilic agents including pyrazolone to synthesize various condensed heterocyclic moieties and derivatized further to pyrimidine derivatives 182-183 (Figure 11). ${ }^{66}$ 
<smiles>Cc1nn(-c2ccccc2)c2c1C(c1ccc(Cl)cc1)C(C#N)=C(N)O2</smiles>

yield $69 \%$<smiles>Cc1nc2c(c(=O)[nH]1)C(c1ccc(Cl)cc1)c1c(C)nn(-c3ccccc3)c1O2</smiles>

yield $51 \%$

\section{Figure 11}

In another series of work, substituted and annulated pyran derivatives were prepared via one pot combinatorial synthesis starting with isatin, cyanoacetic acid derivatives, and various carbonyl compounds. Carbonyl compound ( $\beta$-ketoesters) yielded non-annulated pyran while, annulated pyrans were obtained using $\beta$-diketones, meta-aminophenol, 4-hydroxycoumarin, and pyrazolones ${ }^{67}$ (Scheme 58).

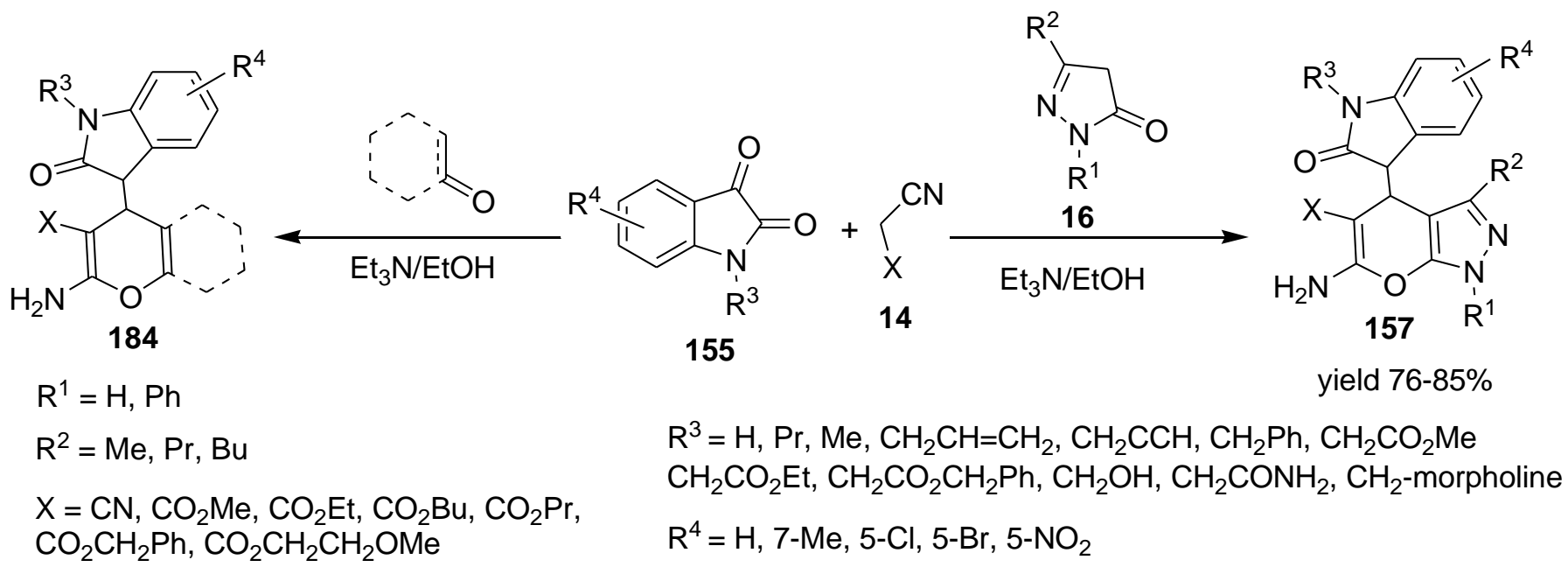

\section{Scheme 58}

It was proposed that the Knoevenagel condensation between isatin and $\mathrm{CH}$-acidic derivative to form alkene $\mathbf{1 5 6}$ is the first step, alkene reacts with the carbonyl compound to give the Michael adduct 185, followed by attack of enolate oxygen on the nitrile group (Thorpe-Ziegler type reaction) and finally tautomerizing to form the target compounds ${ }^{67}$ (Scheme 59).

Kassem and co-workers refluxed 8-hydroxyquinoline-5-sulfonyl chloride (189) either with 2-cyanoacetic acid hydrazide or 3-amino-5-pyrazolone 60 to produce the sulfonyl based pyrazolones 190, 191 which were further reacted with benzylidemalononitriles to provide 8-hydroxyquinoline bearing pyrano[2,3-c]pyrazoles $(192,193)$ (Scheme 60). ${ }^{68}$ The synthesized compounds were tested for antibacterial and antiviral activities, where pyrazolone 190, 191 and pyranopyrazolones 192, 193 showed antibacterial activity while only pyrazolones were found to be potent antiviral agents. 


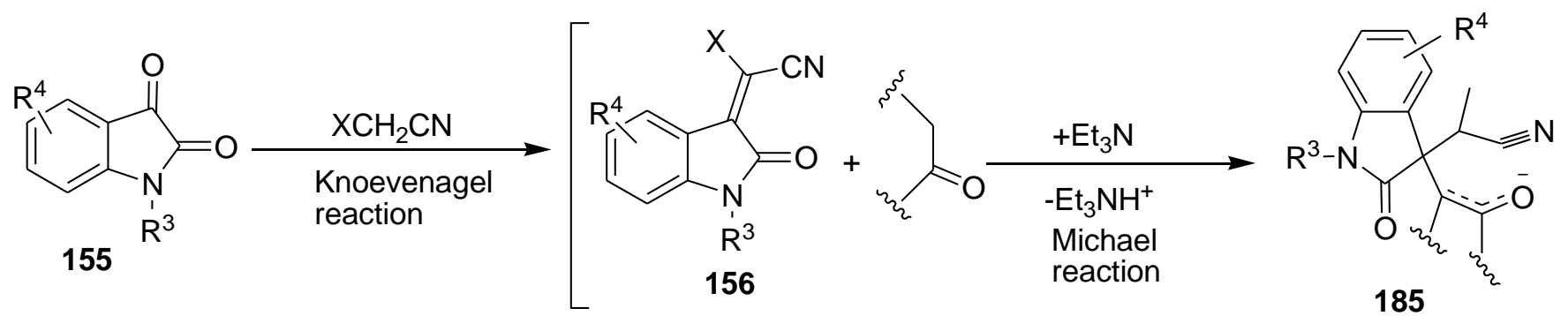

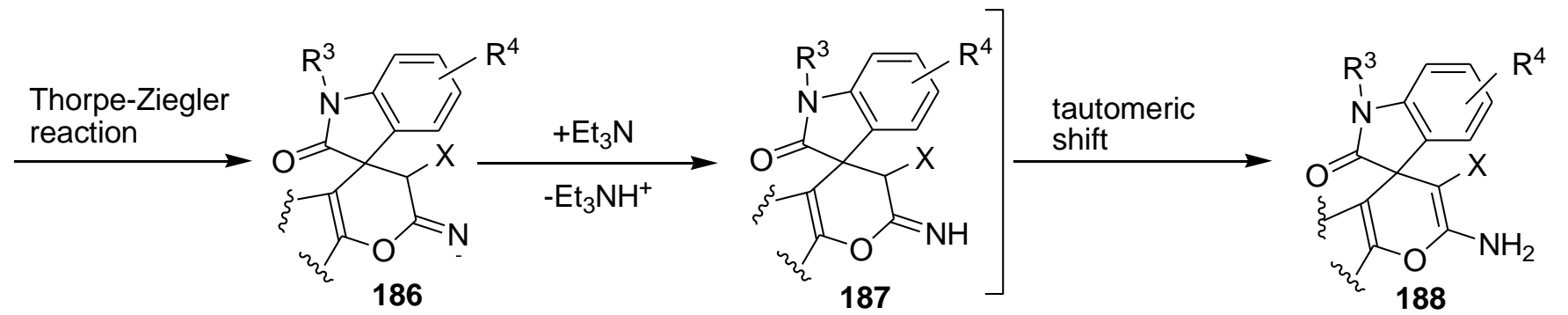

$\mathrm{R}^{3}=\mathrm{H}, \mathrm{Pr}, \mathrm{Me}, \mathrm{CH}_{2} \mathrm{CH}=\mathrm{CH}_{2}, \mathrm{CH}_{2} \mathrm{CCH}, \mathrm{CH}_{2} \mathrm{Ph}, \mathrm{CH}_{2} \mathrm{CO}_{2} \mathrm{Me}$

$\mathrm{CH}_{2} \mathrm{CO}_{2} \mathrm{Et}, \mathrm{CH}_{2} \mathrm{CO}_{2} \mathrm{CH}_{2} \mathrm{Ph}, \mathrm{CH}_{2} \mathrm{OH}, \mathrm{CH}_{2} \mathrm{CONH}_{2}, \mathrm{CH}_{2}$-morpholine

$\mathrm{R}^{4}=\mathrm{H}, 7-\mathrm{Me}, 5-\mathrm{Cl}, 5-\mathrm{Br}, 5-\mathrm{NO}_{2}$

$\mathrm{X}=\mathrm{CN}, \mathrm{CO}_{2} \mathrm{Me}, \mathrm{CO}_{2} \mathrm{Et}, \mathrm{CO}_{2} \mathrm{Bu}, \mathrm{CO}_{2} \mathrm{Pr}$, $\mathrm{CO}_{2} \mathrm{CH}_{2} \mathrm{Ph}, \mathrm{CO}_{2} \mathrm{CH}_{2} \mathrm{CH}_{2} \mathrm{OMe}$

\section{Scheme 59}<smiles>O=S(=O)(Cl)c1ccc(O)c2ncccc12</smiles>

$\mathrm{H}_{2} \mathrm{~N}$<smiles></smiles>

$\mathrm{CNCH}_{2} \mathrm{CONHNH}_{2}$ dioxane, TEA reflux $2 \mathrm{~h}$ TEA reflux 3-6 h

$\mathrm{Ar}=\mathrm{Ph}, 4-\mathrm{Cl}-\mathrm{Ph}, 4-\mathrm{NO}_{2}-\mathrm{Ph}$, 4-MeO-Ph, 4- $\mathrm{NMe}_{2}-\mathrm{Ph}$

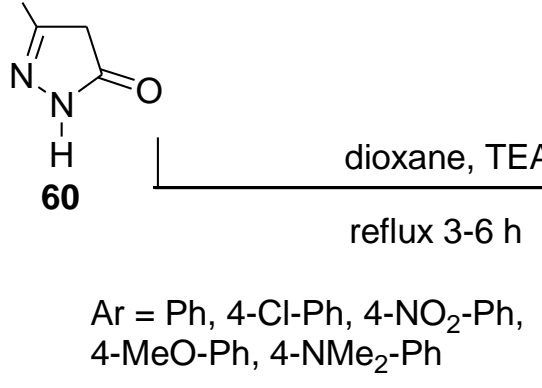

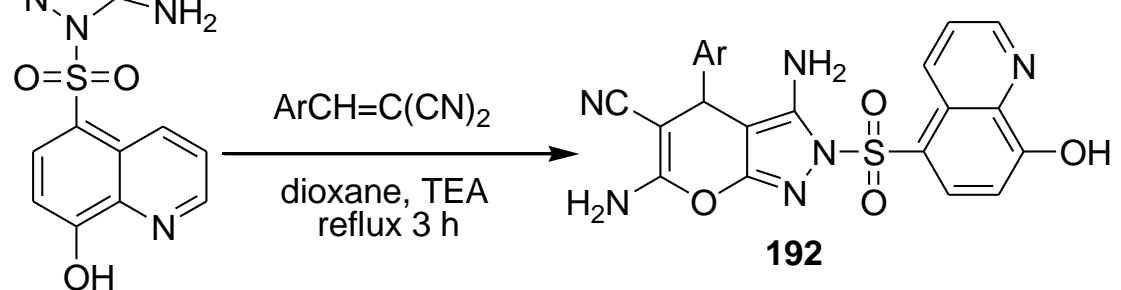

190 yield $66 \%$<smiles>C=CC=CC</smiles><smiles>Cc1c(O)ccc(S(=O)(=O)NC2=NNC(=O)C2)c1C</smiles>

yield $45 \%$

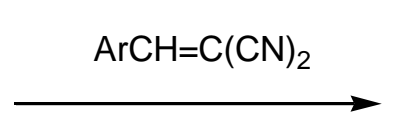

dioxane, TEA

reflux 3-6 $\mathrm{h}$ yield $18-30 \%$<smiles>Nc1cc(Br)c2c(NS(=O)(=O)c3ccc(O)c4ncccc34)nnc-2o1</smiles>

yield $18-34 \%$

\section{Scheme 60}

\subsection{Four components synthesis}

Pyrano[2,3-c]pyrazoles are generally prepared by reacting aldehydes, malononitrile, $\beta$-ketoester and hydrazine with/without catalyst. Various catalyst, solvents, temperature and green techniques have been applied for 
number of carbonyl compounds, $\beta$-keto- ester and un/substituted hydrazine. Most of the reactions were tried without catalyst in different organic solvents such as DMSO, DMF, THF, $\mathrm{MeCN}, \mathrm{CHCl}_{3}, \mathrm{CH}_{2} \mathrm{Cl}_{2}, \mathrm{ClCH}_{2} \mathrm{CH}_{2} \mathrm{Cl}_{2}$, $\mathrm{MeOH}, \mathrm{MeC}_{6} \mathrm{H}_{5}$, EtOH as well as water (DD Water, ultra pure water) (Scheme 61).

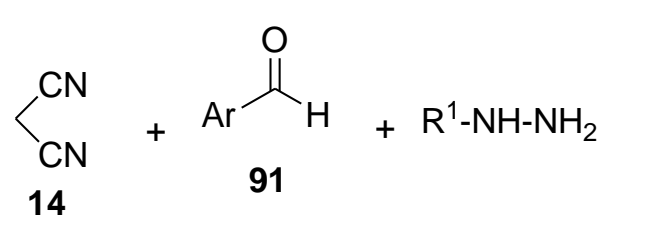

$\mathrm{R}^{1}=\mathrm{H}, \mathrm{Ph} \quad \mathrm{R}^{2}=\mathrm{Me}, \mathrm{Ph}, \mathrm{Et}, \mathrm{Pr}^{\mathrm{i}}$

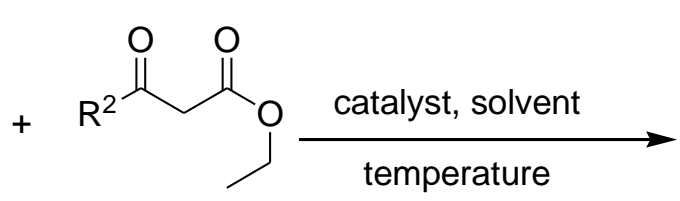

194

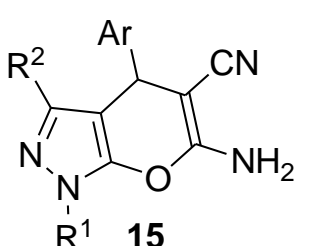

yield $37-99 \%$

$\mathrm{Ar}=\mathrm{Ph}, 2-\mathrm{Cl}-\mathrm{Ph}$, 3-Cl-Ph, 4-Cl-Ph, 2-MeO-Ph, 3-MeO-Ph, 4-MeO-Ph, 2-HO-Ph, 3-HO-Ph, 4-HO-Ph, 2- $\mathrm{NO}_{2}-\mathrm{Ph}$, 3- $\mathrm{NO}_{2}-\mathrm{Ph}$, 4- $\mathrm{NO}_{2}-\mathrm{Ph}$, 4-Me-Ph, 2-F-Ph, 4-F-Ph, 4-CN-Ph, 2-Br-Ph, 3-Br-Ph, 4-Br-Ph, 2- $\mathrm{NH}_{2}-\mathrm{Ph}, 4-\mathrm{NH}_{2}-\mathrm{Ph}$, 4- $\mathrm{CF}_{3}-\mathrm{Ph}, 4-\mathrm{Br}-3-\mathrm{Me}-\mathrm{Ph}, 4-\mathrm{F}-3-\mathrm{Me}-\mathrm{Ph}, 4-\mathrm{Me}_{2} \mathrm{~N}-\mathrm{Ph}$, 3-Me-4-F-Ph, 4-EtO-Ph, 3-EtO-4-HO-Ph, 2-HO-5- $\mathrm{NO}_{2}-\mathrm{Ph}$, 3-HO-4-MeO-Ph, 3-MeO-4-HO-Ph, 2-MeO-4-HO-Ph, 4-MeO-2-HO-Ph, 2-Me-4-MeO-Ph, 4-(OH) ${ }_{2} \mathrm{~B}-\mathrm{Ph}, 2-\mathrm{MeO}-3-$ $(\mathrm{OH})_{2} \mathrm{~B}-\mathrm{Ph}, 3,5$-dichloro-Ph, 2,6-dichloro-Ph, 2,3-dichloro-Ph, 2,4-dichloro-Ph, 2,4-difluoro-Ph, 2,5-dimethyl-Ph, 3,5dimethyl-Ph, 2,4,6-trimethyl-Ph, 2,5-dimethoxy-Ph, 3,4-dimethoxy-Ph, 3,5-dimethoxy-Ph, 3,4,5-trimethoxy-Ph, 2,3,4-trimethoxy-Ph, 5-bromothienyl, 5-chlorothienyl, 1-piperazinyl, 2-pyridinyl, 4-pyrrolyl, 1-naphthyl, 9-anthranyl, $\mathrm{N}$-methylindol-3-yl, 3-pyridinyl, 4-pyridinyl, 2-furanyl, 2-thienyl, butyl, propionyl, isopropyl

\section{Scheme 61}

1. Zolfigol et al. catalyzed synthesis using the highly stable, readily available, metal free, less toxic and reusable organocatalysts such as isonicotinic acid and picolinic acid, where $10 \mathrm{~mol} \%$ of isonicotinic acid at 80 ${ }^{\circ} \mathrm{C}$ showed better results than latter one. ${ }^{69}$ Reaction conditions were suitable for aromatic aldehydes, aliphatic aldehydes, $\mathrm{N}$-phenylhydrazine and hydrazine hydrate.

2. Siddekha and co-workers used imidazole $(0.5 \mathrm{mmol})$ in water at $80{ }^{\circ} \mathrm{C}$ for various aldehydes and did not observe any effect of substituents on yield and rate of reaction. ${ }^{70}$ Geometric parameters and vibrational frequencies of 6-amino-4-(4'-methoxyphenyl)-5-cyano-3-methyl-1-phenyl-1,4-dihydropyrano[2,3-c]pyrazole were also calculated using B3LYP method. Computed values were multiplied with scale factor 0.9614 , to offset anharmonicity in real system for both FTIR and FT-Raman.

3. Kiyani and co-workers carried out synthesis in organic solvents ( $\left.\mathrm{THF}, \mathrm{CHCl}_{3}, \mathrm{CH}_{2} \mathrm{Cl}_{2}, \mathrm{EtOH}\right)$ or water and observed solvent effect on reaction time and yield of products. ${ }^{71}$ Water containing 15 mol\% of sodium benzoate gave best yield. Aldehydes containing donor substituents increased reactivity and yield as compare to electron withdrawing substituents. Additionally, steric hindrance also played role as evidenced by the slower reaction of 2-nitrobenzaldehyde compare to 4-nitrobenzaldehyde. But in case of hydrazine, reactions of phenylhydrazine took longer time than hydrazine hydrate to give products in good yield. Reaction mechanism is represented as Scheme 62.

4. Vasuki and Kumaravel tested potassium carbonate and the organic bases piperidine, triethylamine, diethylamine, pyrrolidine, morpholine, piperazine for synthesis. ${ }^{72}$ Benzaldehyde reacted well without any catalyst, while other aromatic aldehydes reacted in the presence of 5-10 mol\% of piperidine in aqueous media at room temperature. Various mono, di and tri-substituted aromatic aldehydes, hetaryl aldehydes and aliphatic aldehydes used successfully. X-Ray crystallography study confirms the $2-H$ tautomeric form of pyranopyrazoles.

5. Pawar and co-workers developed an inexpensive and environmental friendly method in water/ethanol mixture using 20 mol\% of citric acid. ${ }^{73}$ Various organocatalysts such as oxalic acid, picric acid, succinic acid, $p$ toluenesulfonic acid and sulfamic acid were also tested in different organic solvents at reflux temperature, but 
the best yield was obtained in water/ethanol mixture at $80{ }^{\circ} \mathrm{C}$. Mono and disubstituted benzaldehyde as well as 9-anthracenecarboxaldehydes and furan-2-carbaldehyde showed positive results.

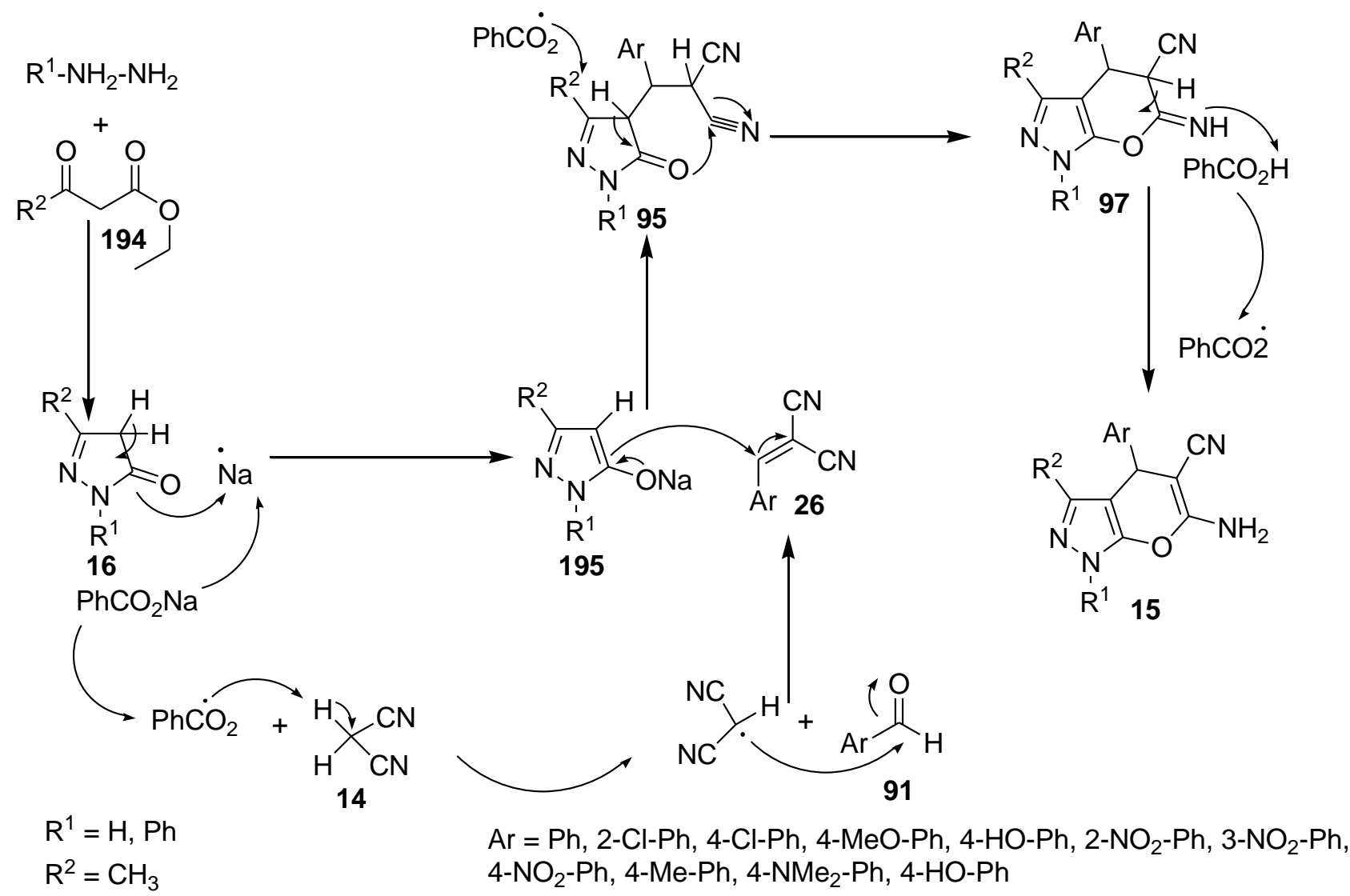

\section{Scheme 62}

6. Madhusudana and Pasha used inexpensive, non-toxic, environmental friendly and easily available iodine catalyst in water solvent at $25{ }^{\circ} \mathrm{C}$ to get excellent yields. ${ }^{74}$ Reaction was unsuccessful in absence of catalyst and solvent, non-polar solvent gave poor yield while increasing the polarity, increased the yield and shortened reaction time. The reaction was applied successfully for aromatic and hetaryl aldehydes.

7. Glycine replaced iodine and reaction was carried out in various organic solvent, obtained excellent yields in water solvent within 5-20 min. ${ }^{75}$ Substituted aldehydes containing electron-donating and electron withdrawing groups worked equally well.

8. In water, reactants stirred in the presence of piperidine catalyst to give pyranopyrazoles, which showed inhibition to steel corrosion. ${ }^{6}$

9. Cetyltrimethylammonium chloride $(\mathrm{CTACl})$ used as a phase transfer catalyst, which increased the hydrophobic surfaces and accelerate the reaction rates of heterogeneous multi-component reactions, to prepare pyranopyrazoles at $90{ }^{\circ} \mathrm{C}^{76}$ Aromatic aldehydes showed good results, but aliphatic aldehydes such as butanal or pentanal showed only small traces of product presumably due to competing of aldol condensation.

10. Kanagaraj and Pitchumani compared the catalytic action of methylamine, diethylamine, triethylamine, piperidine and per-6-amino- $\beta$-cyclodextrin for pyranopyrazoles synthesis where latter, gave excellent yield without solvent in $1 \mathrm{~min} .{ }^{77}$ It was proposed that per-6-ABCD have seven free primary amino groups, thus behaves as an efficient supramolecular host and base catalyst. In the first step, the carbonyl compounds bind within the $C D$ cavity then reacts with malononitrile by Knoevenagel condensation to form 
ylidenemalononitrile. These intermediates have enzyme-like binding, which ensure tight fitting in cavities and facilitates further Michael addition of the ylidenemalononitrile to pyrazolone, followed by cyclization and tautomerization. To support this mechanism, an inclusion complex was formed by mixing equimolar amounts of adamantane and per-6-ABCD and used as catalyst, absence of any product confirms inculsion to per- 6$A B C D$ cavities essential for pyranopyrazoles synthesis.

11. An easily available, cheap, and non-toxic catalyst sodium bisulphite was used under ultrasound irradiation without any solvent. ${ }^{78}$ It was assumed that ultrasonic cavitations created microscopic internal high pressure and high temperature. Electron donating and/or withdrawing substituents of aromatic aldehydes showed no effect on yield of pyranopyrazoles.

12. Alumina and alumina supported reagents have well known surface properties and specific porous structures, hence the catalytic efficiency of $\alpha$-alumina, basic alumina and KF-alumina examined using $30 \mathrm{~mol} \%$ of each catalyst. ${ }^{79}$ The order of reactivity is found to be alumina $>$ KF-alumina > basic alumina. The higher activity of $\alpha$-alumina was attributed to the amphoteric nature and the greater surface area allowing for greater adsorption of the reactants on its surface. Aromatic, poly functional and aliphatic aldehydes used under this condition.

13. Reddy and Garcia carried out eco friendly synthesis using montmorillonite K-10 as catalyst. The reaction has an advantage of catalyst recovery and reusability for several time. ${ }^{80}$

14. Phenylboronic acid ( $5 \mathrm{~mol} \%$ ) in water at reflux temperature was used for aromatic and hetero-aromatic aldehydes. ${ }^{81}$ Electron donating or withdrawing groups, at any position ( $p, m$ or $o$ ) of aldehyde, gave good yield, but electron withdrawing substituted aldehydes reacted slowly while aliphatic aldehydes gave poor yields. The reaction mechanism proposed to involve initial binding of $\mathrm{PhB}(\mathrm{OH})_{2}$ with carbonyl oxygen.

15. Kumar and co-workers used inexpensive, mild, water-tolerant and eco-friendly tetraethyl ammonium bromide (10 mol\%) catalyst in boiling water for aromatic, hetero-aryl and aliphatic aldehydes. ${ }^{82}$

16. Nagarajan and Reddy synthesized pyranopyrazoles without solvent and catalyst at room temperature within 3-11 min. $^{83}$ Aldehydes bearing electron-releasing groups at the para position gave better yield than electron-withdrawing groups at the same position. Similarly, disubstituted aldehyde with electron-donating groups at para and meta positions required shorter reaction time and gave higher yield. Reaction conditions worked equally for aliphatic aldehydes.

17. Moeinpour and Khojastehnezhad used $\mathrm{Ni}_{0.5} \mathrm{Zn}_{0.5} \mathrm{Fe}_{2} \mathrm{O}_{4}$ nanoparticles in water to get maximum yield at room temperature. ${ }^{84}$ Catalyst was separated easily by an external magnet, reused six times, studied by XRD patterns which showed no change in structure, weight and reactivity. Initially, nanoparticles were prepared by mixing equimolar solutions of $\mathrm{FeCl}_{3}, \mathrm{NiCl}_{2}, \mathrm{ZnCl}_{2}$ and $\mathrm{NaOH}$, then coating silica and polyphosphoric acid on the nanoparticles. The nanoparticles were found to be spherical, average size less than $70 \mathrm{~nm}$ in diameter and narrowly distribute.

18. Babaie and Sheibani prepared MgO nanoparticles by treating aqueous magnesium hydroxide gels, magnesium nitrate and liquid ammonia and used these nanoparticles for pyranopyrazoles synthesis using malononitrile, aromatic aldehydes, phenyl hydrazine/hydrazine hydrate and different ethyl 3-alkyl-3oxopropanoate in acetonitrile at room temperature in 5-45 $\mathrm{min}^{85}$

19. Various iron oxides such as $\mathrm{Fe}_{3} \mathrm{O}_{4}, \mathrm{Fe}_{3} \mathrm{O}_{4}$ nanoparticles and recovered $\mathrm{Fe}_{3} \mathrm{O}_{4}$ nanoparticles were compared for pyranopyrazoles synthesis where nanoparticles in fresh and recovered state showed excellent results. ${ }^{86}$ Nanoparticles were prepared by treating $\mathrm{FeCl}_{3} \cdot 6 \mathrm{H}_{2} \mathrm{O}, \mathrm{FeCl}_{2} \cdot 4 \mathrm{H}_{2} \mathrm{O}$ with $\mathrm{NaOH}$. Out of different solvents, ultra pure water was found to be excellent. 
20. Saha and co-workers used 10 mol\% of $\mathrm{ZrO}_{2}$ nanoparticles for MCR pyranopyrazoles synthesis at room temperature in water/ethanol mixture (6: 1). ${ }^{87}$ The structure of $\mathrm{ZrO}_{2}$ was confirmed as tetragonal and $17 \mathrm{~nm}$ in particle size.

21. Borhade and Uphade prepared ZnS nanoparticles by mixing and stirring together a solution of zinc nitrate, sodium dodecyl sulphate and sodium sulphide and confirmed the elemental composition by EDAX spectrum and structure by XRD, SEM, TEM techniques. ${ }^{88}$ These particles were found to be single-phase, hexagonal with average crystallite size of $20 \mathrm{~nm}$ and compared with $\mathrm{FeCl}_{3}, \mathrm{SnCl}_{4}, \mathrm{P}_{2} \mathrm{O}_{5}, \mathrm{ZnCl}_{2}$, bulk $\mathrm{ZnS}$ and $\mathrm{ZnS}$ nanopatricles. Nanoparticles technique was found most effective catalyst for synthesis of pyranopyrazoles at room temperature.

22. Ebrahimipour et al. Carried out condensation of 5-bromo-2-hydroxybenzaldehyde with 2-amino-4methylphenol to form a ligand, which reacted with $\mathrm{Ni}(\mathrm{OAc})_{2} \cdot 4 \mathrm{H}_{2} \mathrm{O}$ and 1-Methylimidazole to form mixed ligand complex $[\mathrm{Ni}(\mathrm{L})(\mathrm{mimi})]$ either at reflux temperature to obtain bulk form or under ultrasonic irradiation to get nano-sized particles. ${ }^{89}$ Both forms were tested for pyranopyrazoles synthesis and revealed that mixed ligand $[\mathrm{Ni}(\mathrm{L})(\mathrm{mimi})]$ in either form, gave better yields, but nanoparticles are more efficient. The structure of the nanoparticles was found to be composed of finely dispersed nanorods with average diameter $45 \mathrm{~nm}$.

23. Shinde and co-workers synthesized pyranopyrazoles in water at reflux, but obtained poor yield. ${ }^{90}$ To $^{\circ}$ increase efficiency silica gel 60 used as a catalyst, which increased the yield of product and decreased reaction time at room temperature. Reaction was found to be equally good for small scale, large scale, electron withdrawing and electron donating substituted aldehydes.

24. Nimbalkar and co workers initially synthesized triethylammonium hydrogen sulphate[ $\left.\mathrm{Et}_{3} \mathrm{NH}\right]\left[\mathrm{HSO}_{4}\right]$ and used it to carry out multicomponenet synthesis of pyranopyrazole at room temperature. ${ }^{88}$ The synthesized compounds were subjected to molecular docking and in vitro anticancer study where were found active against cancer cell lines.

25. The Ionic liquid 1-butyl-3-methylimidazolium tetraflouroborate containing bases such as triethylamine,

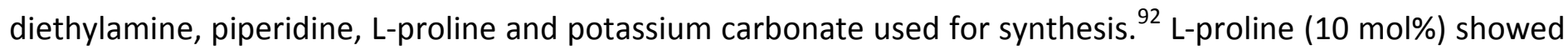
excellent results at $50{ }^{\circ} \mathrm{C}$ within 5-10 min. Other ionic liquids including 1-butyl-3-methylimidazolium hexaflourophosphate $\left[\mathrm{Bmim}_{\mathrm{PF}}\right.$ and 1-butyl-3-methylimidazolium bromide $[\mathrm{Bmim}] \mathrm{Br}$ were also used and showed good result except for 4-chlorobenzaldehyde.

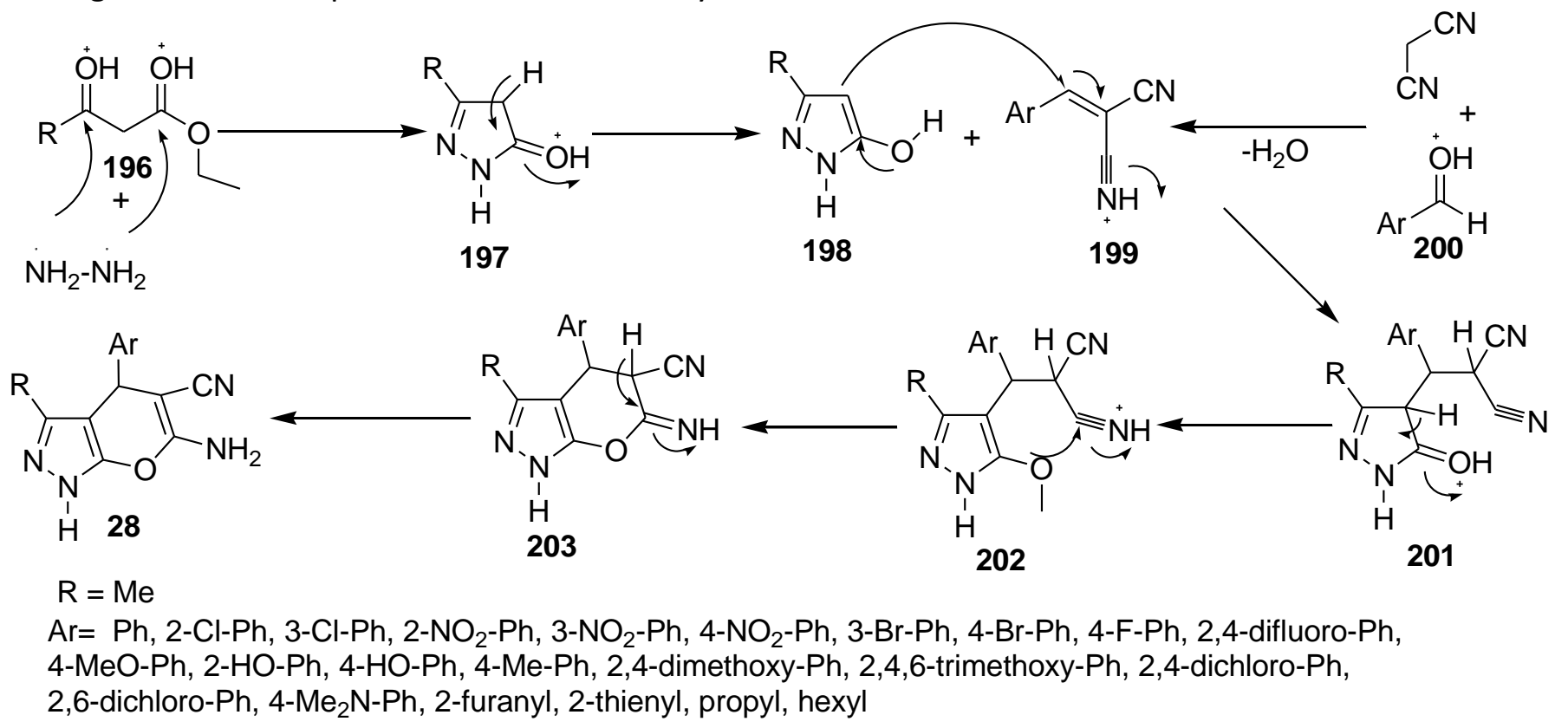

\section{Scheme 63}


26. Chavan and co-workers compared the catalytic activity of silicotungstic acid with $\mathrm{FeCl}_{3}, \mathrm{ZnCl}_{2}, \mathrm{SnCl}_{4}$, $\mathrm{P}_{2} \mathrm{O}_{5}$ and $\mathrm{CAN}$, where the former showed excellent result at $60{ }^{\circ} \mathrm{C} .{ }^{93}$ Aromatic aldehydes produced high yield as compare to aliphatic aldehydes. NOE study of pyranopyrazoles confirmed its $2-H$ tautomeric form.

27. A mixture of anhydrous choline chloride and anhydrous urea in a $2: 1$ ratio heated at $50{ }^{\circ} \mathrm{C}$ to form a homogenous liquid that catalyses the formation of pyranopyrazoles (62-95\%) under solvent free condition. ${ }^{94}$ The reaction was found to be applicable for hydrazine hydrate, phenylhydrazine, various $\beta$-ketoestsers such as ethyl isobutyroylacetoacetate, ethyl benzoylacetoacetate, aromatic and hetero aromatic aldehydes.

28. Ebrahimi and co-workers used a task specific ionic liquid named, 3-methyl-1-(4-sulphonic acid)butylimidazolium hydrogen sulphate $\left[\left(\mathrm{CH}_{2}\right)_{4} \mathrm{SO}_{3} \mathrm{HMIM}\right]\left[\mathrm{HSO}_{4}\right]$ to carry out synthesis at room temperature. ${ }^{95}$

29. Devkate and co-workers also used same Bronsted acid ionic liquid in various aprotic and protic solvents, but obtained excellent results under solvent free condition. ${ }^{96}$

30. Amin and co-workers replaced malononitrile with 2-cyanoacetamide and refluxed with other three reactants in methanol to obtain 5-carboxamide pyranopyrazoles (204) and found to be antibacterial and antifungal agents ${ }^{97}$ (Figure 12).

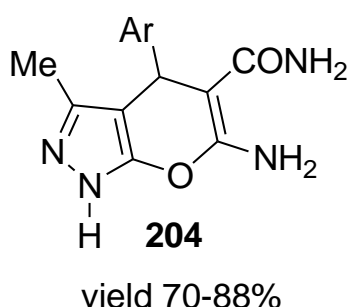

yield $70-88 \%$
$\mathrm{Ar}=4-\mathrm{Cl}-\mathrm{Ph}, 3,4-$ dimethoxy-Ph,

2,3,4-trimethoxy- $\mathrm{Ph}$,

3-HO-4-MeO-Ph,

4-HO-3-MeO-Ph,

2-Cl-6-Me-quinolin-3-yl,

$1 \mathrm{H}$-indol-3-yl

\section{Figure 12}

In four components synthesis, mostly reported mechanism involves the following steps (i) Reaction of hydrazine and the $\beta$-ketoester to form pyrazolone, which tautomerizes to the enol form 198. For this purpose, various $\beta$-ketoesters such as ethyl acetoacetate, phenyl acetoacetate, ethyl 3-alkyl-3-oxopropanoate, ethyl isobutyroylacetoacetate and ethyl benzoylacetoacetate have been treated with hydrazine hydrate and phenylhydrazine (ii) Synthesis of ylidenemalononitrile $\mathbf{2 6}$ by Knoevenagel condensation of aldehydes and malononitrile. Mono substituted aromatic aldehydes, disubstituted aromatic aldehydes, hetero-aromatic aldehydes, alicyclic aldehydes as well as ketones have been used (iii) Reaction of pyrazolone and ylidenemalononitrile to form Michael adduct 206/208 either following path a or b (iv) Cyclization of Michael adduct involving attack of pyrazolone on nitrile group to form cyclic intermediate $207 / 209$ by path c or $d$ ( $v$ )

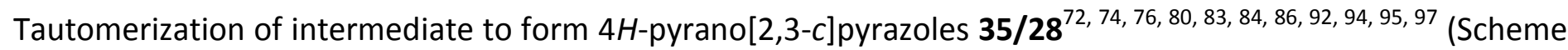
64). 


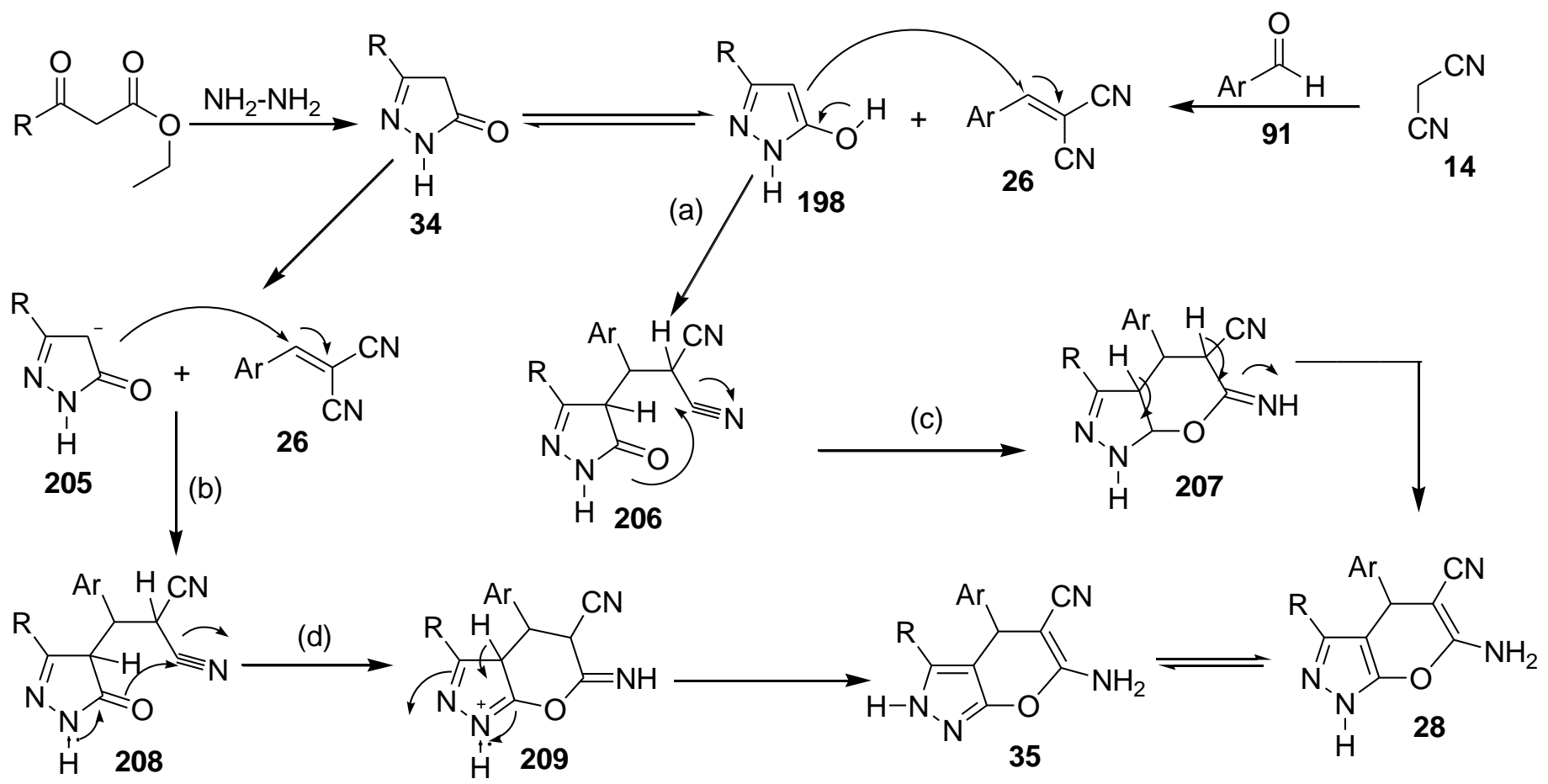

$\mathrm{R}=\mathrm{Me}, \mathrm{Ph}, \mathrm{Et}, \mathrm{Pr}^{\mathrm{i}}$

$\mathrm{Ar}=\mathrm{Ph}$, 2-Cl-Ph, 3-Cl-Ph, 2-MeO-Ph, 3-MeO-Ph, 4-MeO-Ph, 3- $\mathrm{NO}_{2}-\mathrm{Ph}, 4-\mathrm{NO}_{2}-\mathrm{Ph}, 4-\mathrm{Me}-\mathrm{Ph}, 4-\mathrm{Cl}-\mathrm{Ph}, 4-\mathrm{HO}-\mathrm{Ph}$, 4-F-Ph, 2-Br-Ph, 4-EtO-Ph, 4-Br-Ph, 3-Br-Ph, 4-Br-3-Me-Ph, 4-CF ${ }_{3}$, 4-CN-Ph, 4-F-3-Me-Ph, 4-NMe $-\mathrm{Ph}$, 3-HO-4$\mathrm{MeO}-\mathrm{Ph}, 2,4,6$-trimethyl-Ph, 3,4-dimethoxy-Ph, 3,5-dimethoxy-Ph, 2,5-dimethoxy- $\mathrm{Ph}, 2,3$-dichloro-Ph, 2,4dichloro-Ph, 2,3,4-trimethoxy-Ph, 3,4,5-trimethoxy-Ph, 2-Cl-6-Me-quinolin-3-yl, 1H-indol-3-yl, 3-pyridinyl, $\mathrm{N}$ methylindol-3-yl, 4-pyridinyl, 2-furanyl, 2-thienyl, isopropyl

Scheme 64. Catalyst free synthesis of pyranopyrazole.

Another proposed mechanism involves binding of carbonyl oxygen with metals of catalyst such as $\mathrm{PhB}(\mathrm{OH})_{2},{ }^{81} \mathrm{MgO},{ }^{85} \mathrm{ZrO},{ }^{87}$ mixed ligand $[\mathrm{Ni}(\mathrm{L})(\mathrm{mimi})],{ }^{90}$ or with hydrogen of silica gel ${ }^{91}$ to promote the reaction. Afterwards reaction proceeded according to the first mechanism (Scheme 65).

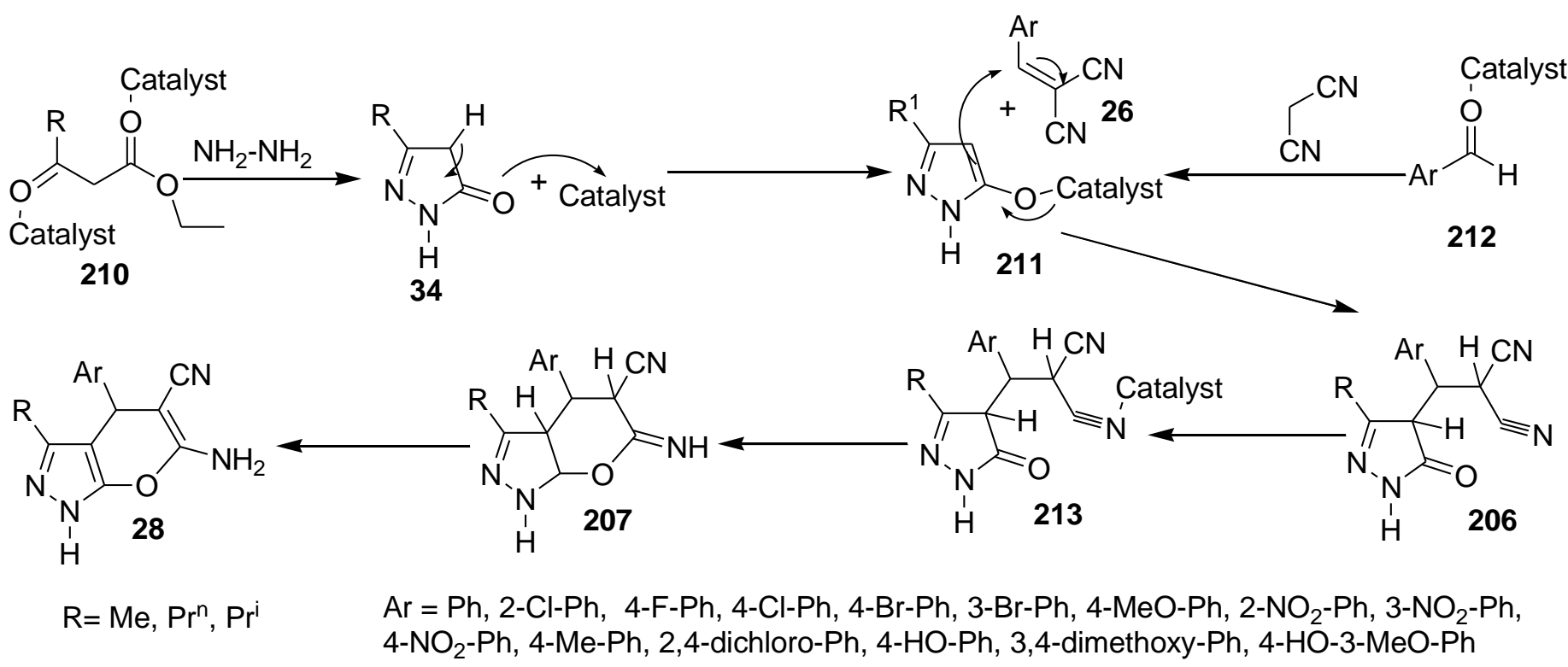

Scheme 65. Catalyst-initiated synthesis of pyranopyrazole. 
Brahmachari and Banerjee prepared pyrano[2,3-c]pyrazoles (28) and various pyran-annulated heterocycles 215 using urea (10 mol\%) in water/ethanol (1:1) mixture (Scheme 66). ${ }^{98}$<smiles>N#CC1=C(N)OC2=C(C(=O)c3ccccc3C2=O)C1Br</smiles>

215<smiles>CCOc1ccccc1C(=O)O</smiles>

yield $84-91 \%$

$$
\mathrm{Ar}^{\prime}=3-\mathrm{NO}_{2}-\mathrm{Ph}, 2 \text {-furanyl, 4-pyridyl } \quad \mathrm{R}=\mathrm{Me}
$$<smiles>[R]c1c2c(n(CC(=O)OCC)c1[R])OC(N)=C(C#N)C2Br</smiles>
yield $84-86 \%$

\section{Scheme 66}

Litvinov and co-workers successfully carried out regioselective synthesis in boiling ethanol containing triethylamine for electron withdrawing/donating substituted aldehydes, naphthaldehyde, hetero-aromatic aldehydes, $N$-substituted piperidin-4-one, tetrahydrothiopyran-4-one, isatins and other saturated cyclic ketones but, failed for pyvaloylacetic ester because of the steric constraints (Scheme 67). ${ }^{99}$

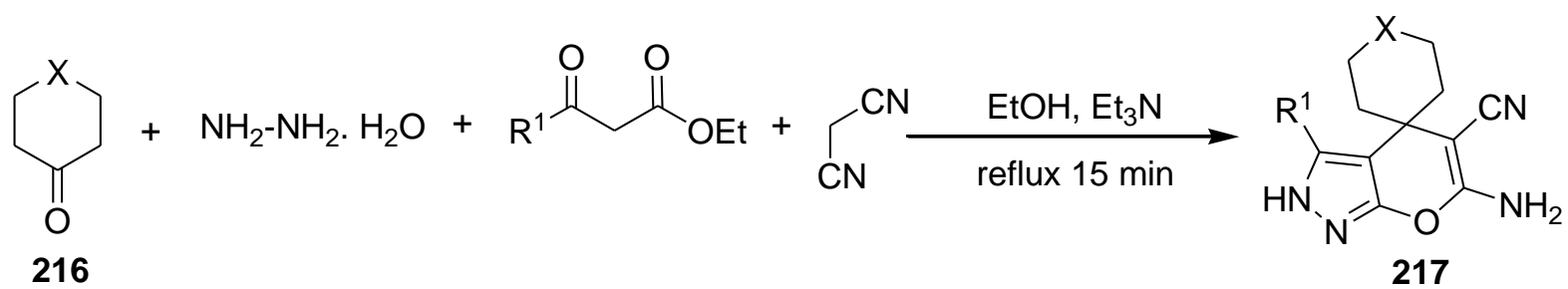

$X=\mathrm{S}, \mathrm{NCOMe}, \mathrm{NCO}_{2} \mathrm{Et}, \mathrm{N}-\mathrm{CO}_{2} \mathrm{Bu}^{\mathrm{t}}$

$\mathrm{R}^{1}=\mathrm{Me}, \mathrm{Et}, \mathrm{Pr}, \mathrm{Ph}, \mathrm{CH}_{2}-\mathrm{OMe}, \mathrm{Me}_{3} \mathrm{C}$

yield $46-85 \%$

\section{Scheme 67}

Sequence of reactants was found important for pyranopyrazoles synthesis as isatin monohydrazone $\mathbf{2 1 9}$ is formed by adding all four reactants or three reactants (oxindole, hydrazine hydrate and $\beta$-ketoesters) simultaneously (Scheme 68). ${ }^{99}$

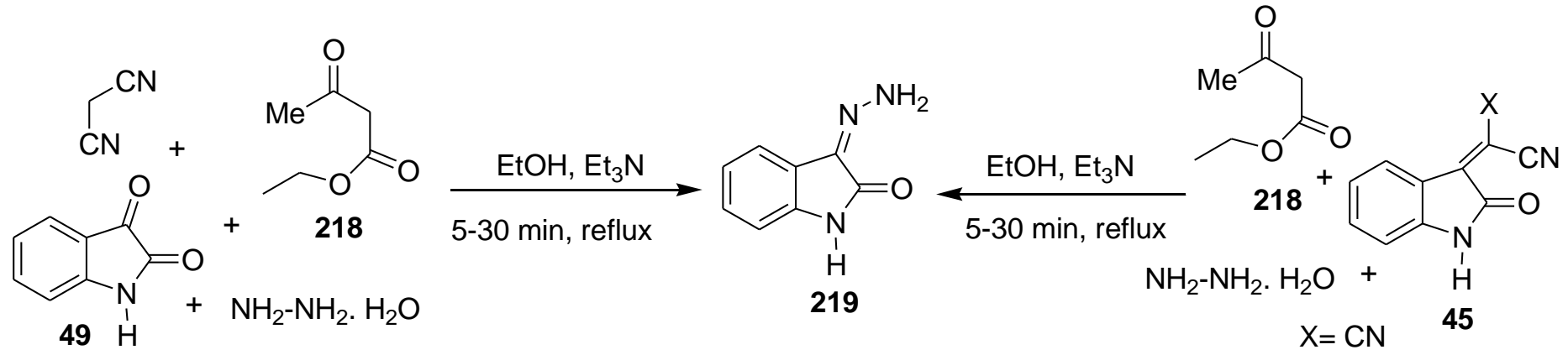

\section{Scheme 68}


Ahadi and co-workers allowed malononitrile, hydrazine hydrate, $\beta$-ketoesters to react with isatin and acenaphthylene-1,2-dione (220) in water containing piperidine to get spiroindoline and acenaphthylene pyranopyrazoles 157, 221 (Scheme 69). ${ }^{100}$ Reaction mechanism was assumed to involve initial synthesis of pyrazolone and alkene as intermediates followed by Michael addition to get $\mathbf{2 2 2}$ which tautomerize to final product (Scheme 70). Synthesized compounds showed good antibacterial activity.

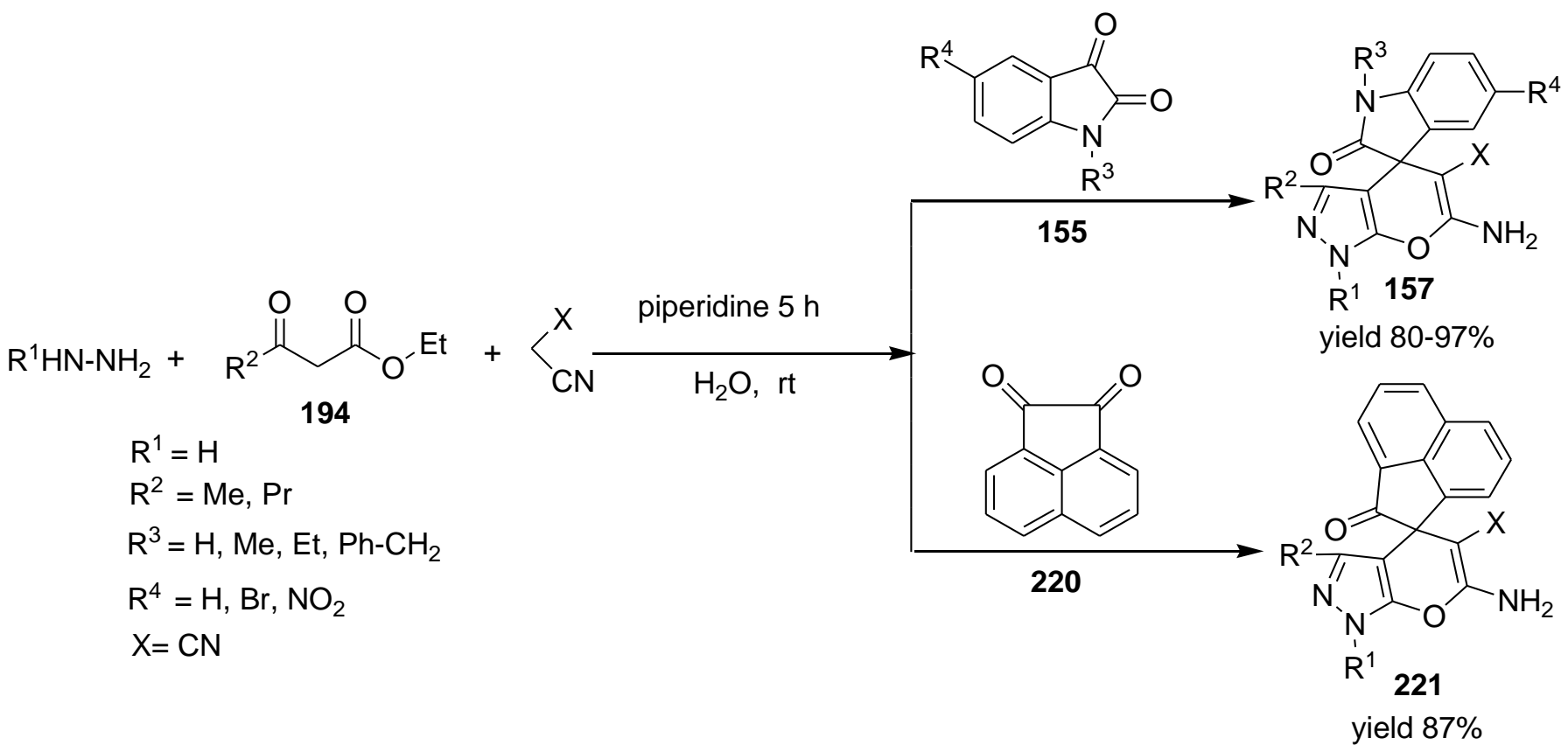

\section{Scheme 69}

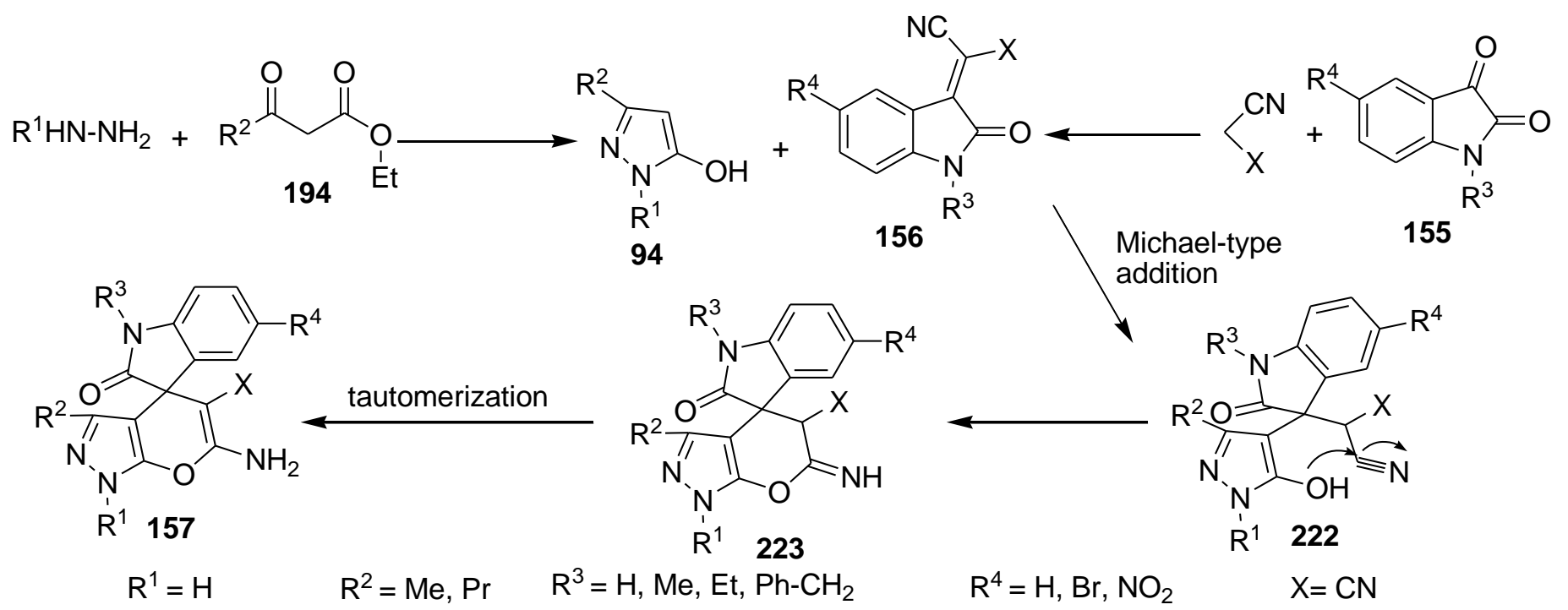

\section{Scheme 70}

Koohshari and co workers carried out regio- and chemio-selective synthesis of ethyl acetate bearing pyranopyrazoles in water/ethanol (8:2) without any catalyst at temperature range of $25-82{ }^{\circ} \mathrm{C} .{ }^{101} \mathrm{Different}$ dialkyl 3-oxopentanedioate (224) and carbonyl compound such as aldehydes, isatin and acenaphthenequinone have been applied to obtain a variety of pyranopyrazoles 226-228 (Scheme 71). The reaction mechanism for 
synthesis of $\mathbf{2 2 6}$ was presented and assumed to involve formation of various intermediates $\mathbf{2 2 9 - 2 3 2}$ (Scheme 72).

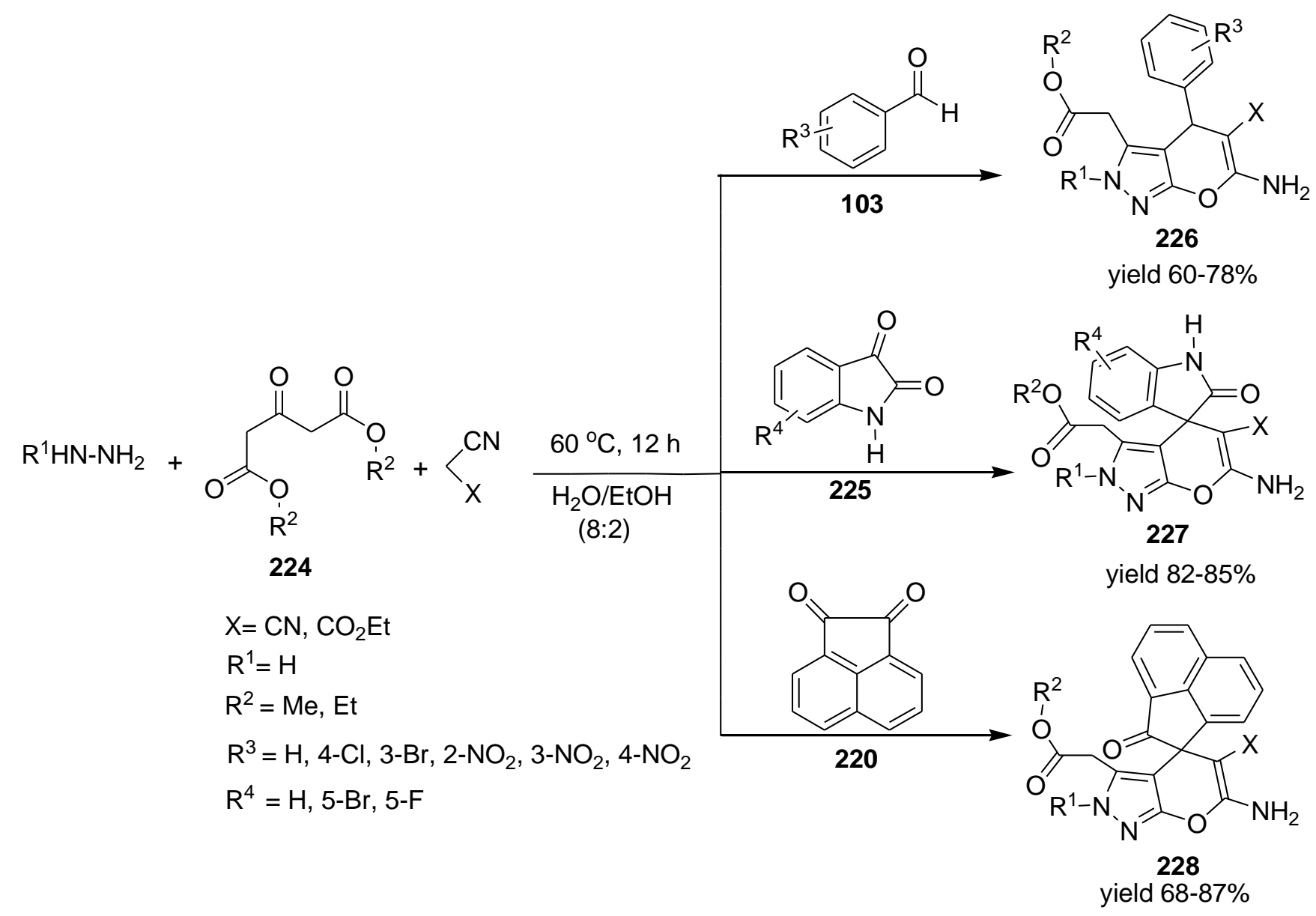

\section{Scheme 71}

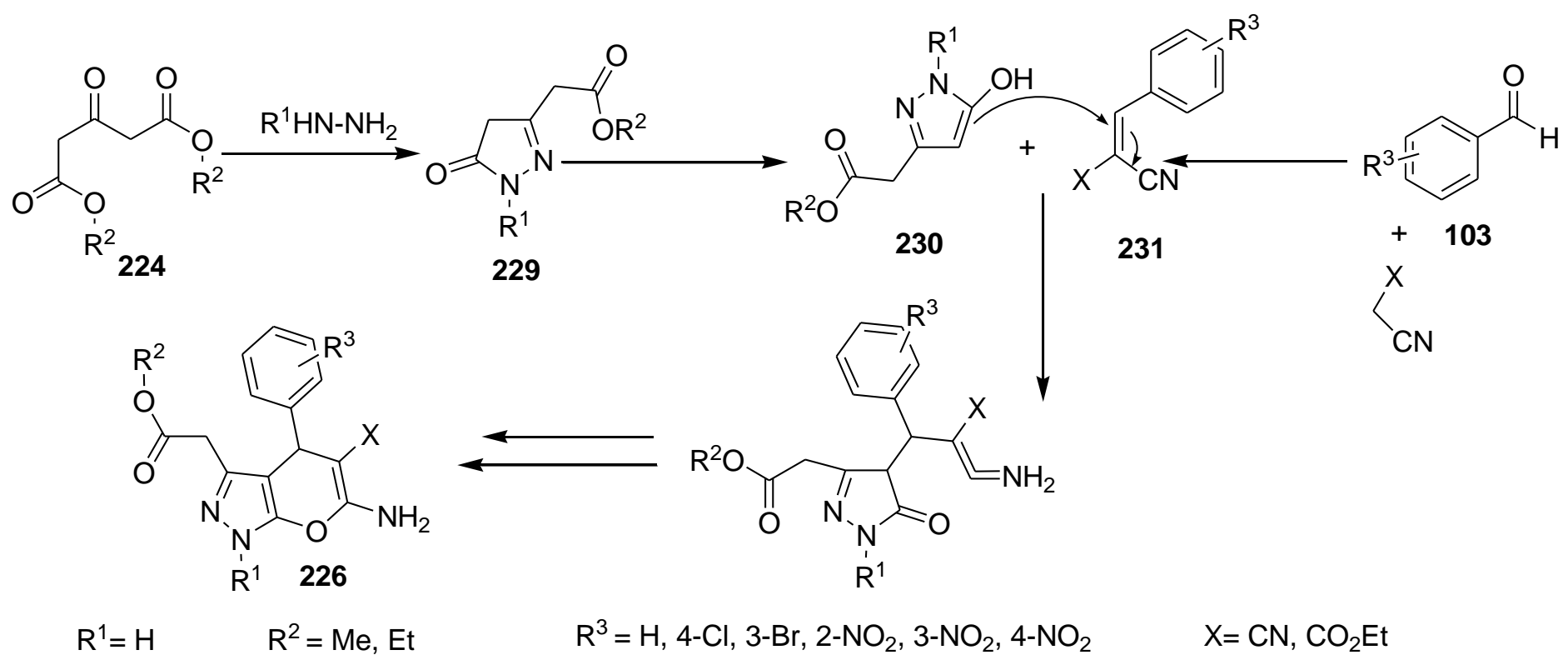

Scheme 72 
Pore et al. used acetylenic esters 233 instead of $\beta$-ketoesters in water/ethanol mixture at reflux temperature to desire indolinepyranopyrazole $234 .^{102}$ The reaction protocol worked for isatin, 5-substituted isatin, $\mathrm{N}$-substituted isatin, diethyl acetylenedicarboxylate (DEAD) and dimethyl acetylenedicarboxylate (DMAD) (Scheme 73). Reactivity of isatin possessing electron donating or withdrawing substituents did not show any significant difference, but product $\mathbf{2 3 4}$ obtained by only adding reactants in following sequence (i) hydrazine hydrate (ii) acetylenic ester (iii) solvent (iv) isatin (v) malononitrile. The reaction mechanism involves fast and exothermic reaction of DEAD/ DMAD with malononitrile to form ethoxypyrazolone other reaction steps are similar.<smiles>[X]CC[N+]#N</smiles>

233<smiles>[X]C1=C(N)Oc2n[nH]c([R])c2C12C(=O)N([R])c1ccc([R])cc12</smiles>

234

$$
\mathrm{R}^{1}=\mathrm{Me}, \mathrm{Et} \quad \mathrm{R}^{2}=\mathrm{H}, \mathrm{Me}, \mathrm{Et} \quad \mathrm{R}^{3}=\mathrm{H}, \mathrm{I}, \mathrm{Cl}, \mathrm{Me}, \mathrm{OMe} \quad \mathrm{X}=\mathrm{CN} \quad \text { yield } 80-91 \%
$$

\section{Scheme 73}

Similarly, Wang and co-workers prepared spiroarylpyranopyrazoles in ethanol solvent containing triethylamine (Scheme 74). ${ }^{103}$ Structures were confirmed by X-ray.

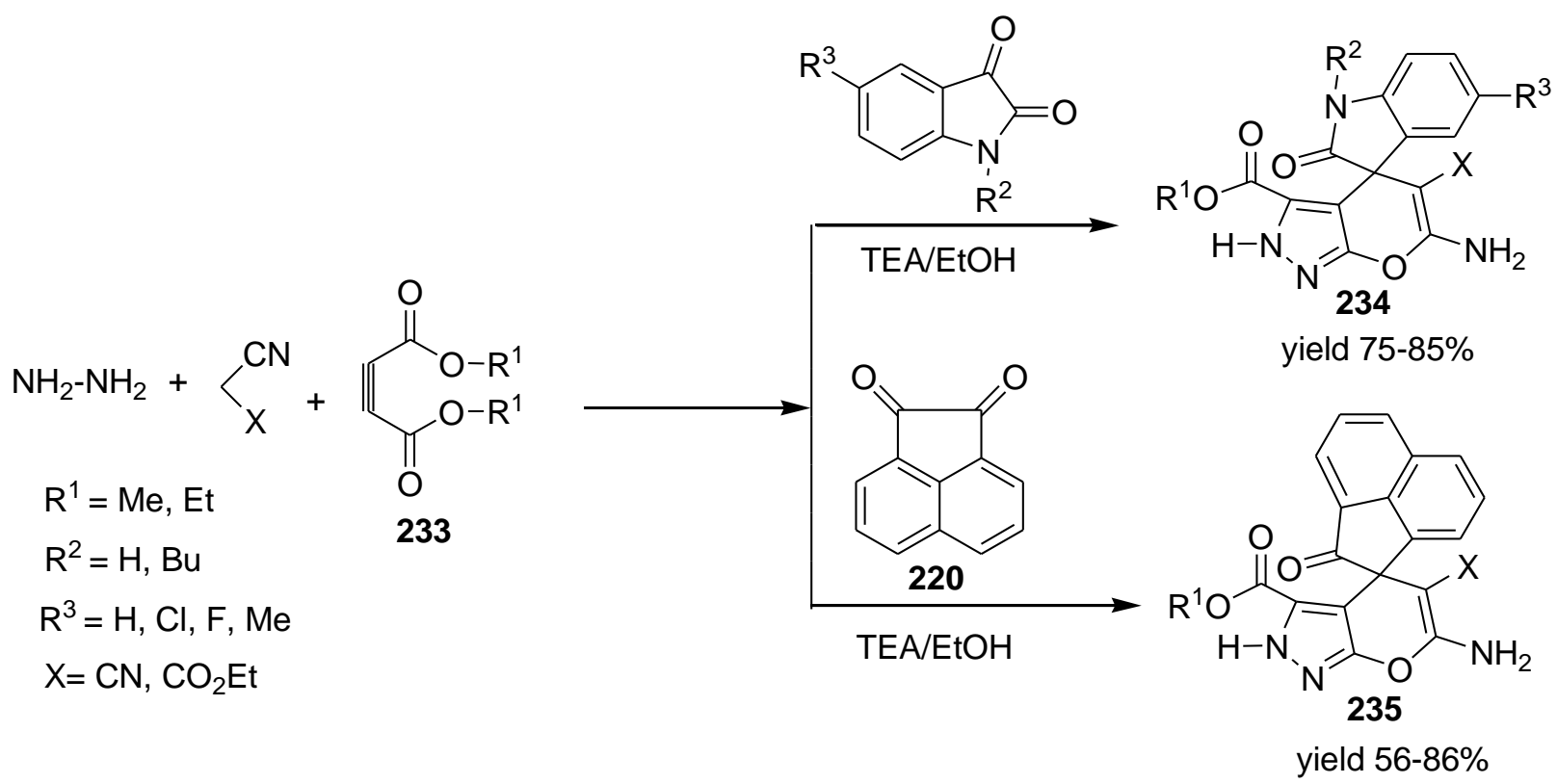

\section{Scheme 74}

The mechanism of both reactions is summarized and represented below ${ }^{102,103}$ (Scheme 75). 


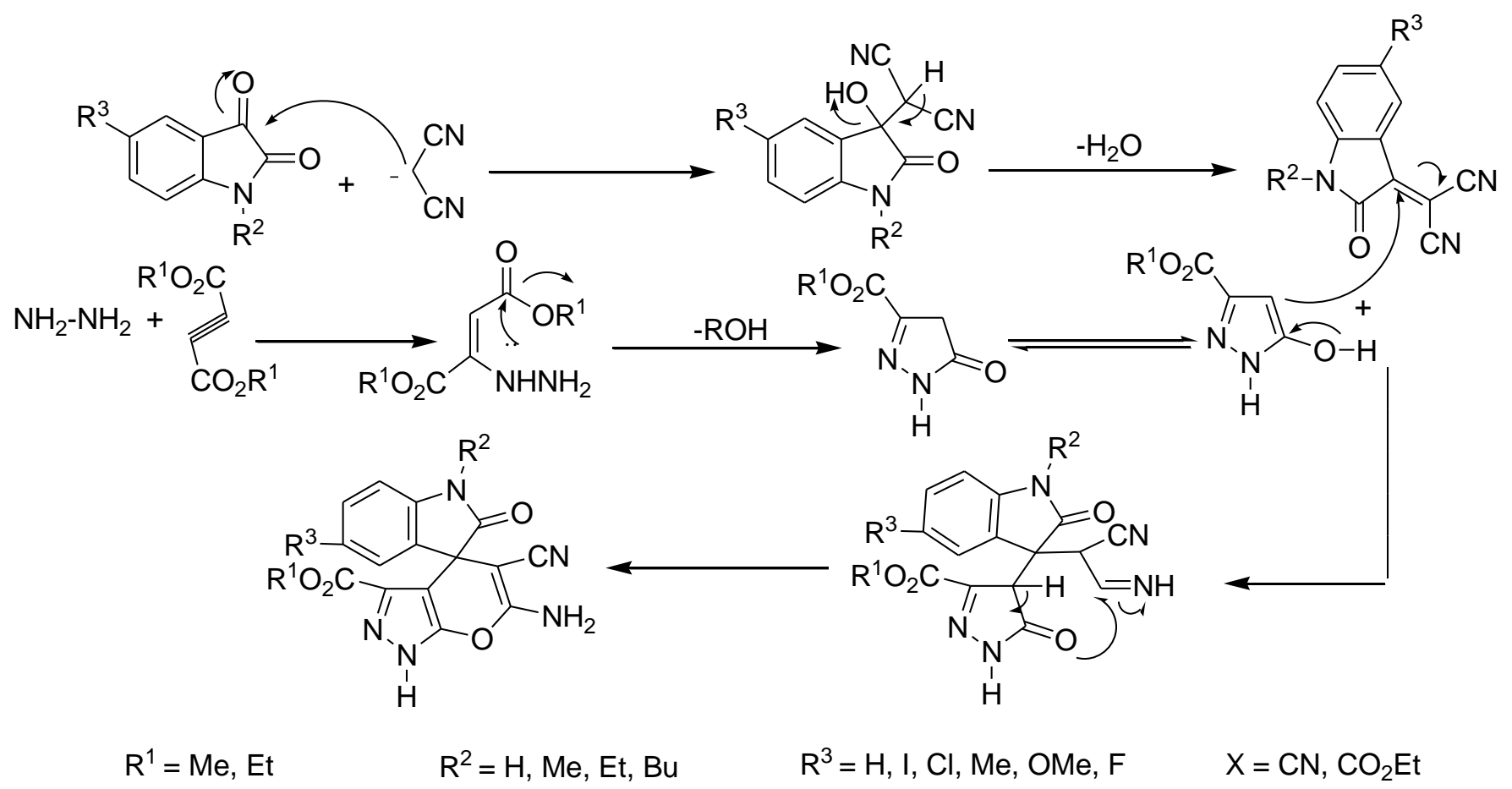

\section{Scheme 75}

Meglumine (10 mol\%) in ethanol/water mixture was used as catalyst for the reaction of carbonyl compounds such as aldehydes, ketone, isatin or acenaphtylene-1,2-dione, to get pyranopyrazoles 28, 236-238 (Figure 13). ${ }^{104}$<smiles>[R]c1n[nH]c2c1C(Br)C(C#N)=C(N)O2</smiles>

yield $85-95 \%$

$\mathrm{Ar}=\mathrm{Ph}$

$\mathrm{R}=\mathrm{Me}, \mathrm{Et}$

$\mathrm{R}^{1}=\mathrm{H}, \mathrm{Me}$<smiles>[R]c1nn([2H])c2c1C([R7])([R])C(C#N)=C(N)O2</smiles>

yield $85-95 \%$<smiles>[R][R]1ccc2c(c1)C1(C(=O)N2)C(C#N)=C(N)Oc2c([R])nn([Z10])c21</smiles>

yield $85-93 \%$<smiles>[R6]c1n[nH]c2c1C1(C(=O)c3cccc4ccccc34)C(C#N)=C(N)O[C@H]21</smiles>

yield $90 \%$

$\mathrm{R}^{2}=\mathrm{Ph}, 2-\mathrm{Cl}-\mathrm{Ph}, 3-\mathrm{Cl}-\mathrm{Ph}, 4-\mathrm{Cl}-\mathrm{Ph}, 2-\mathrm{F}-\mathrm{Ph}, 3-\mathrm{F}-\mathrm{Ph}, 4-\mathrm{F}-\mathrm{Ph}, 2-\mathrm{NO}_{2}-\mathrm{Ph}, 4-\mathrm{NO}_{2}-\mathrm{Ph}$, 4-HO-Ph, 4-Me-Ph, 4-MeO-Ph, 2,3,4-trimethoxy-Ph, 4-prn $-\mathrm{Ph}, 4-\mathrm{pen}^{\mathrm{n}}-\mathrm{Ph}, 4-\mathrm{MeS}-\mathrm{Ph}$, 4-methylcyclohexyl, cyclohexyl, cyclopentyl, cyclobutyl, cyclohexyl, 4-isobutyl-Ph, 2-thienyl, decanyl, 1-naphthyl, 2-MeO-5-isopropyl-Ph, 2-furanyl, 4-pyridinyl $\mathrm{R}^{3}=\mathrm{H}, \mathrm{Me}, \mathrm{F}, \mathrm{Cl}, \mathrm{Br}, \mathrm{NO}_{2}$

Figure 13

Ambethkar and co-workers ground reactants together in a pestle mortar using L-proline (10 mol\%) as the catalyst, aryl aldehydes with the electron withdrawing groups gave better yields (Scheme 76). ${ }^{105}$ Compounds 239 were tested for in vitro antioxidant and antimicrobial activities. 


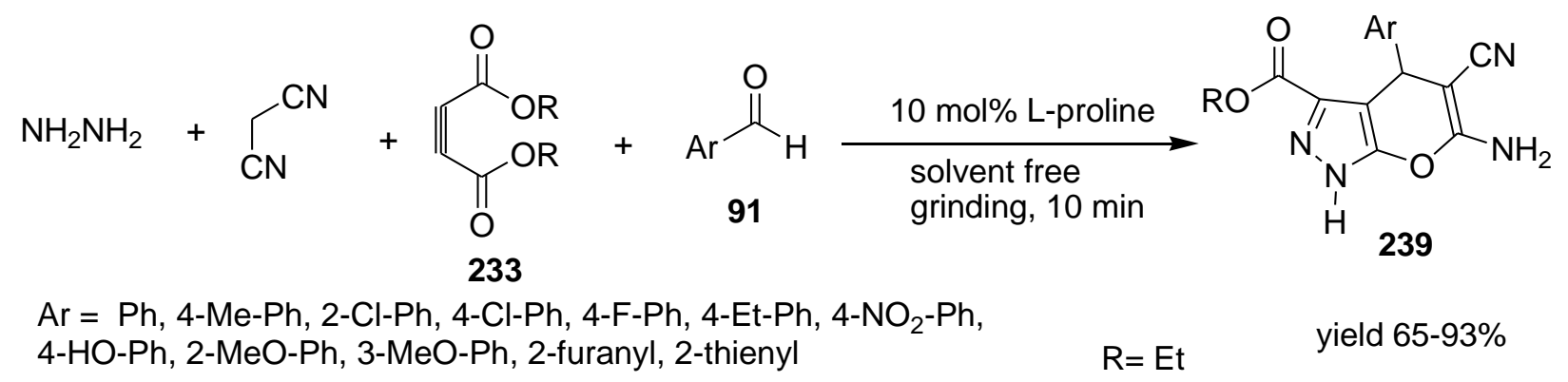

\section{Scheme 76}

Zonouz and co-workers prepared pyranopyrazoles 240 without catalyst in water at $50-60{ }^{\circ} \mathrm{C}$ in $66-88 \%$ yield $^{106}$ (Figure 14).<smiles>COC(=O)c1n[nH]c2c1C(c1ccccc1)C(C#N)=C(N)O2</smiles>

yield $64-84 \%$
$\mathrm{R}=\mathrm{H}, 2-\mathrm{NO}_{2}, 4-\mathrm{NO}_{2}, 3-\mathrm{NO}_{2}, 4-\mathrm{MeO}$, 3-OH, 2-Br, 4-Br, 2-Me, 3-Me

\section{Figure 14}

Triethylamine, piperidine or chitosan as catalysts were used to obtain pyranopyrazoles 241 at reflux temperature either by four components or reacting pyrazolone with benzylidemalononitrile. ${ }^{107}$ NOE difference experiments confirmed the attachment of hydrogen to second nitrogen of pyrazole. An intermediate 242, was obtained by replacing ethyl acetoacetate with ethyl cyanoacetate and pyrano[2,3-c]pyrazol-4-one (243) by refluxing pyrazolone with cyanoacetic acid and acetic anhydride (Figure 15).<smiles>[R7]C1([R7])C(C#N)=C(N)Oc2n[nH]c(C)c21</smiles>

241

yield $53-91 \%$

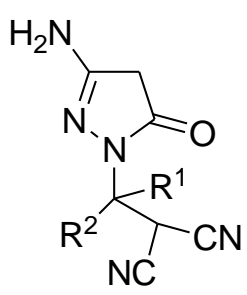

242

yield $65 \%$<smiles>Cc1[nH]nc2oc(N)cc(=O)c12</smiles>

yield $16 \%$

$\mathrm{R}^{1}=\mathrm{Ph}, \mathrm{Me}, 4-\mathrm{MeO}-\mathrm{Ph}, 2$-furanyl

$\mathrm{R}^{2}=\mathrm{H}, \mathrm{Me}$

\section{Figure 15}

Jayabal and Paramasivan used a versatile synthon, $N$-methyl-1-(methylthio)-2-nitroethenamine (158) under solvent-free condition to get chemo-and regioselective 6 - $N$-methylpyranopyrazoles 244 in $76-86 \%$ yields (Scheme 77). ${ }^{108}$ 


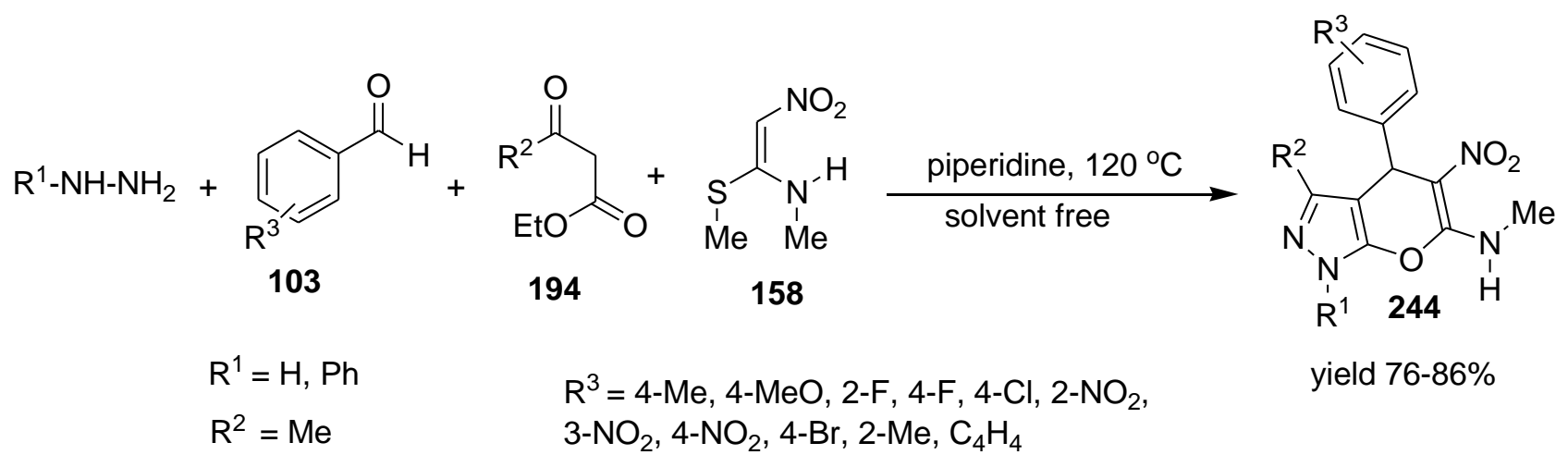

\section{Scheme 77}

The reaction mechanism is supposed to involve ${ }^{108}$ (i) Synthesis of pyrazolone (ii) Knoevenagel condensation of pyrazolone with aldehydes to form the Michael acceptor 245 (iii) An immediate Michael-type addition of nitroketene- $N, S$-acetal to give intermediate 246 (iv) Cyclization by eliminating a molecule of methanethiol 247 (v) Tautomerization. It was also proposed that intermediate $\mathbf{2 4 6}$ may undergo $\mathrm{N}$-attack and by eliminating a molecule of water to yield $\mathbf{2 4 8}$, but this was not isolated (Scheme 78 ).

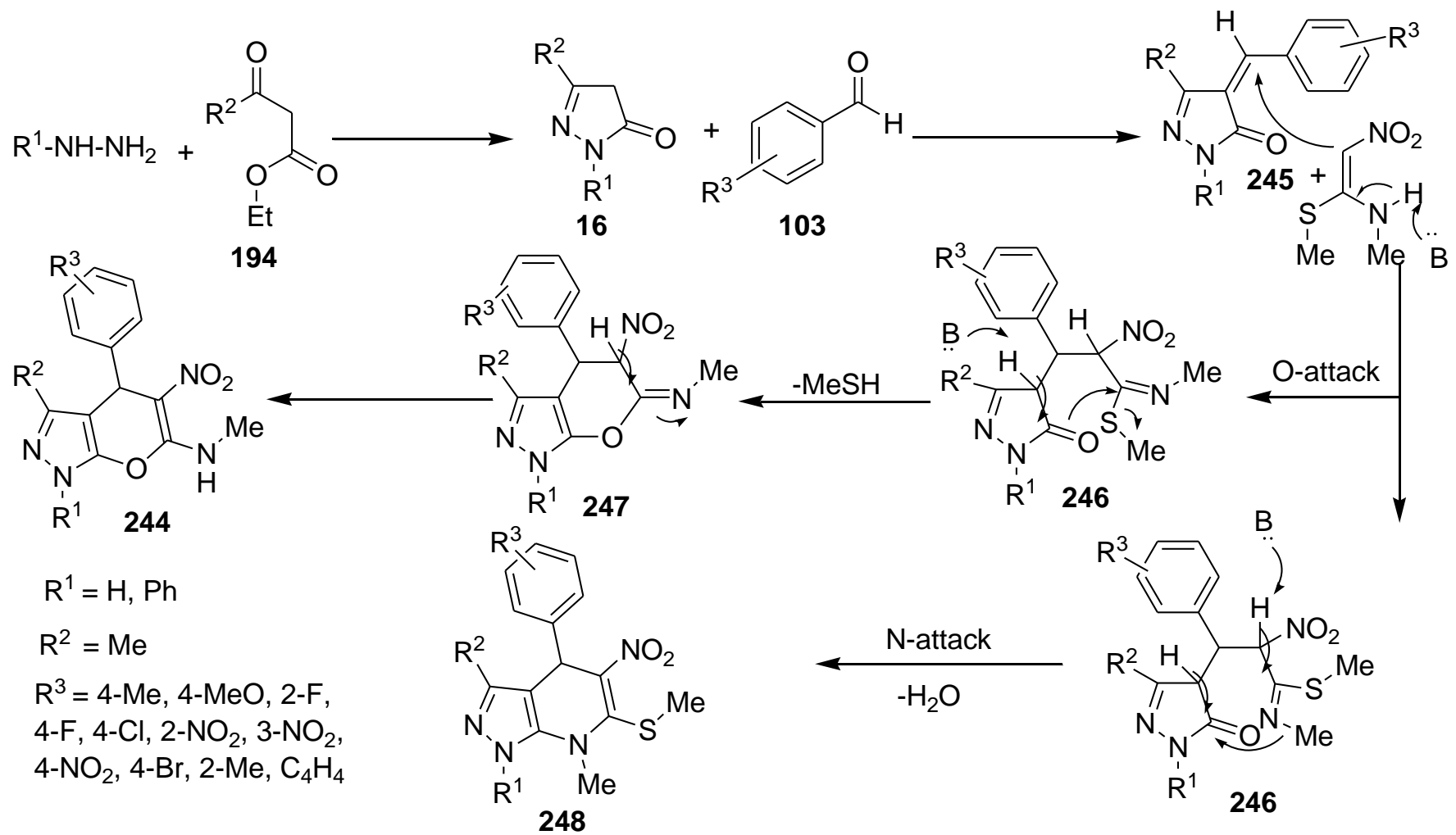

\section{Scheme 78}

Alizadeh and Bayat developed a concise and regioselective route for spiropyranopyrazoles 250,251 by reaction of indane-1,2,3-trione (249), malononitrile, hydrazine derivatives with $\beta$-ketoesters and dimethyl acetylenedicarboxylate (Scheme 79). ${ }^{109}$ 


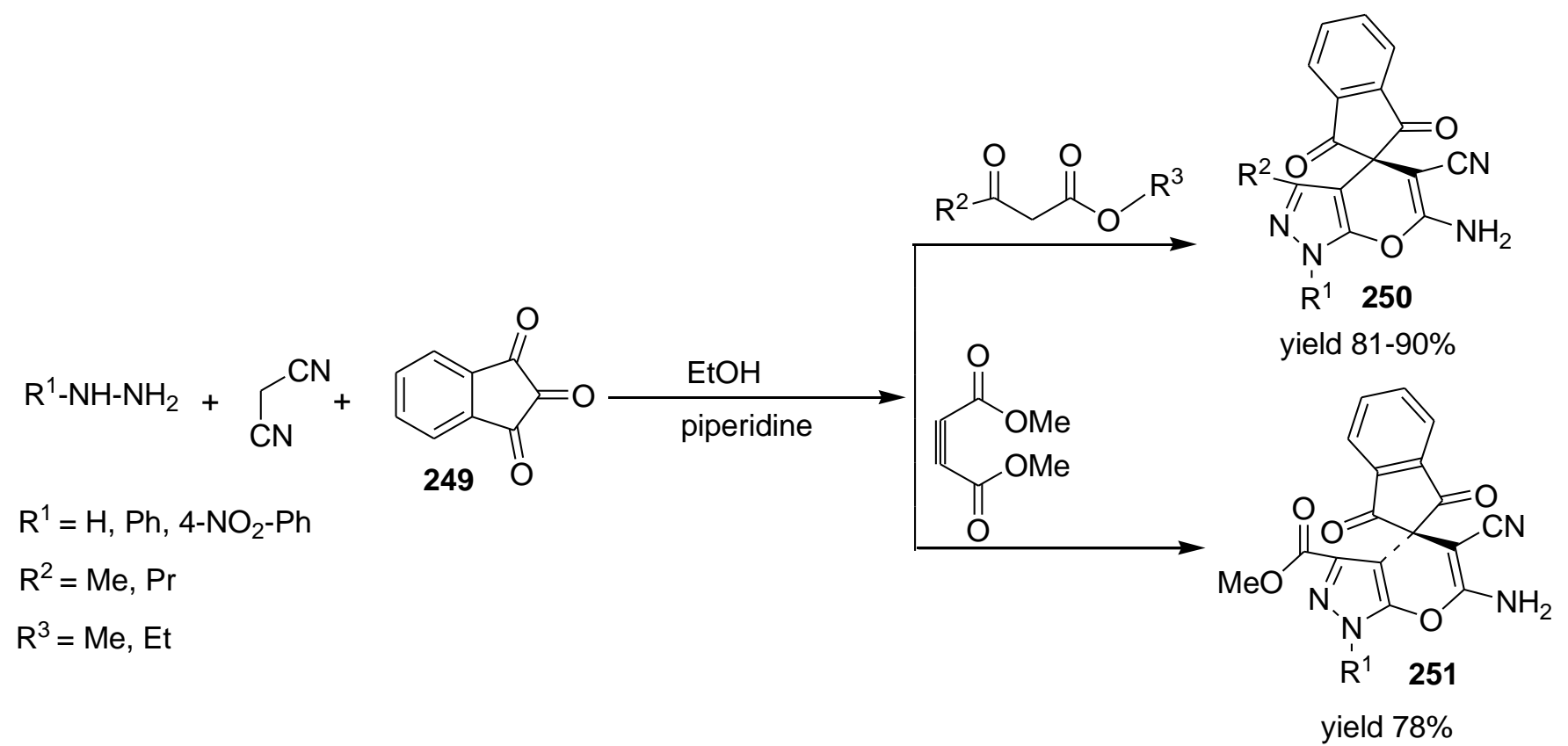

\section{Scheme 79}

Reaction was found to be effective for a variety phenyl derivatives, however electron withdrawing groups at the 2-position, resulted in the formation of oxa-aza-[3.3.3]propellanes (252) ${ }^{109}$ (Figure 16).

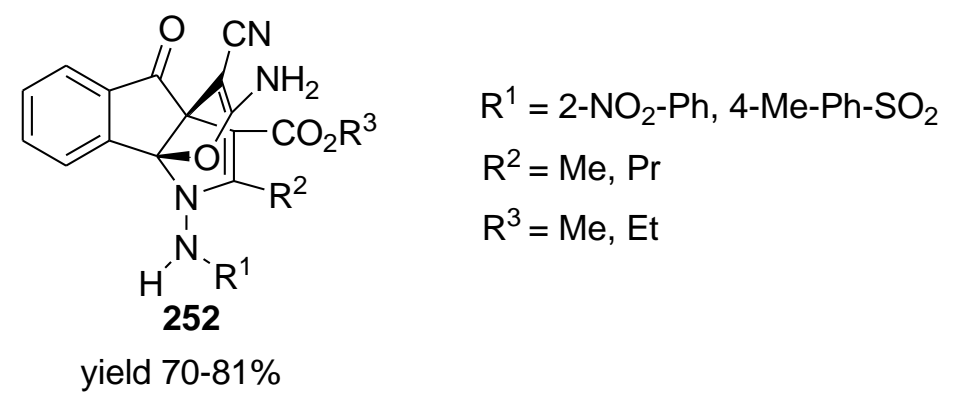

\section{Figure 16}

\subsection{Five Component Synthesis}

Lu and co-workers carried out a one pot synthesis of pyranopyrazoles involving Suzuki coupling between 4bromobenzaldehyde (253) and arylboronic acid (254) under dehalogenating effect of $\mathrm{KF} .2 \mathrm{H}_{2} \mathrm{O}$ in the presence of $\mathrm{Pd} / \mathrm{C}$ at $80{ }^{\circ} \mathrm{C} .{ }^{110}$ Firstly, 4-bromobenzaldehyde and arylboronic acid were added to form substituted biphenyl aldehydes later on, other reagents were added and allowed to react for 5-6 hr. 


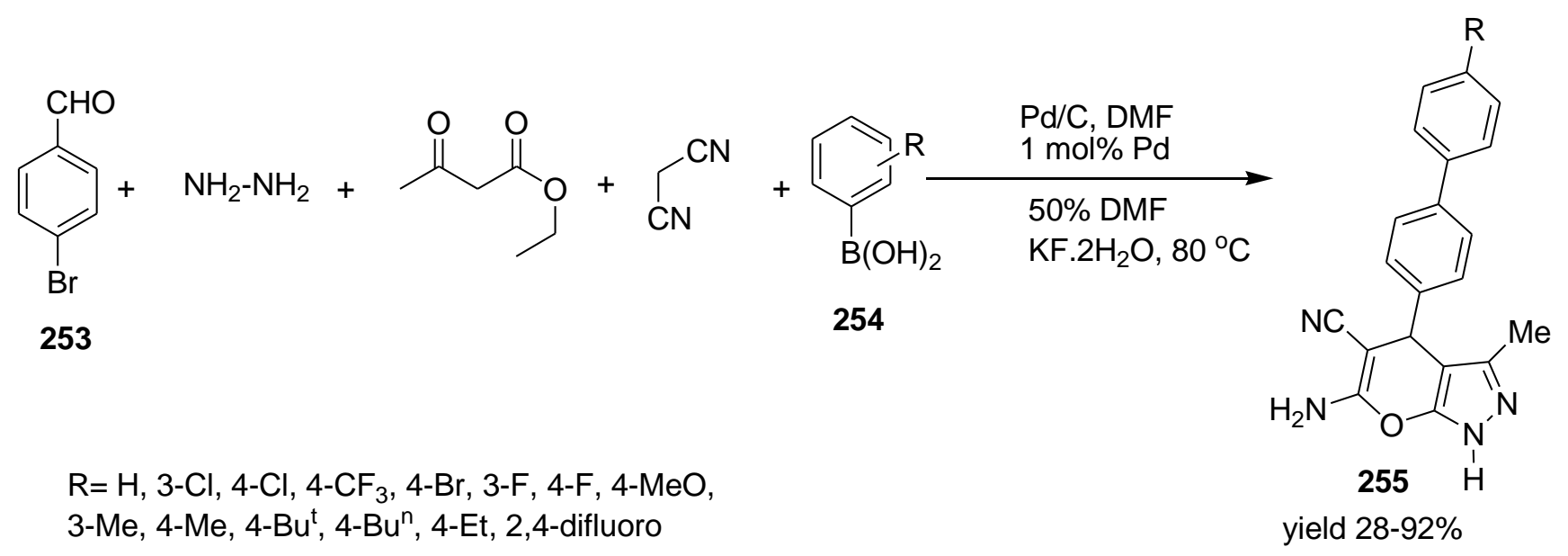

\section{Scheme 80}

Another five components synthesis involves a mixture of acid chlorides, Meldrum's acid (256), aromatic aldehydes, hydrazine hydrate and malononitrile in the presence of Cul nanoparticles. ${ }^{111}$ Catalyst prepared by ultrasonic cleaning of $\mathrm{CuSO}_{4}$ in $\mathrm{HCl}$ and characterized by SEM, XRD, EDAX analysis.

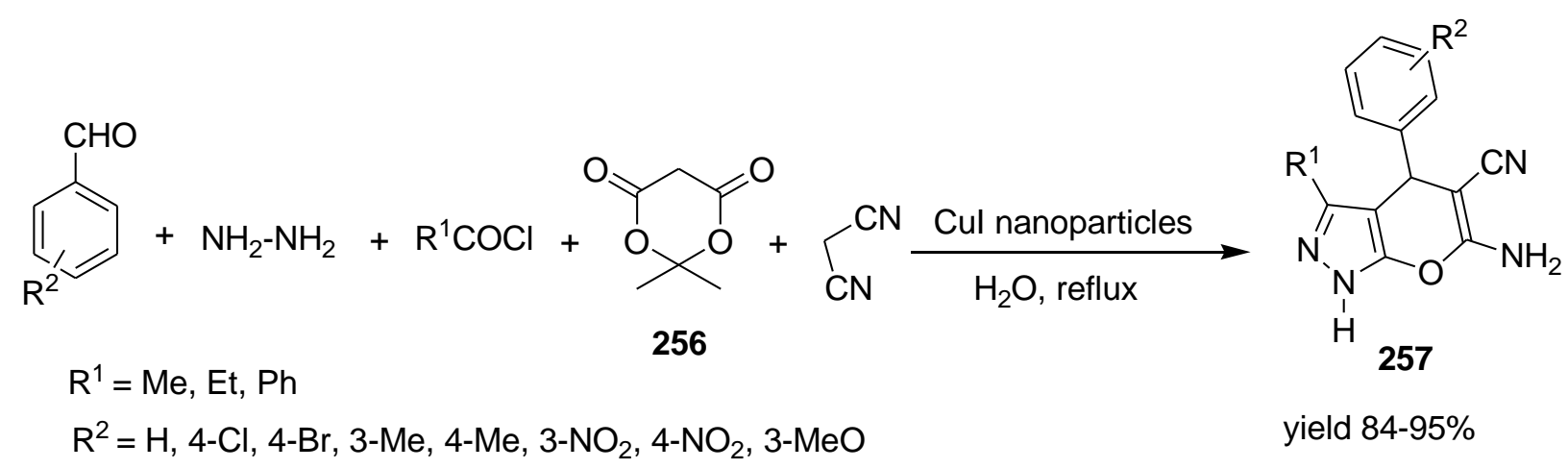

\section{Scheme 81}

The reaction mechanism was proposed to involve synthesis of $\beta$-ketoester in situ by nucleophilic substitution of Meldrum's acid to acetyl chloride. ${ }^{111}$ Other steps include synthesis of pyrazolone, alkene and Michael adduct followed by cyclization and tautomerization (Scheme 82). 
<smiles>[R10]OCl</smiles>

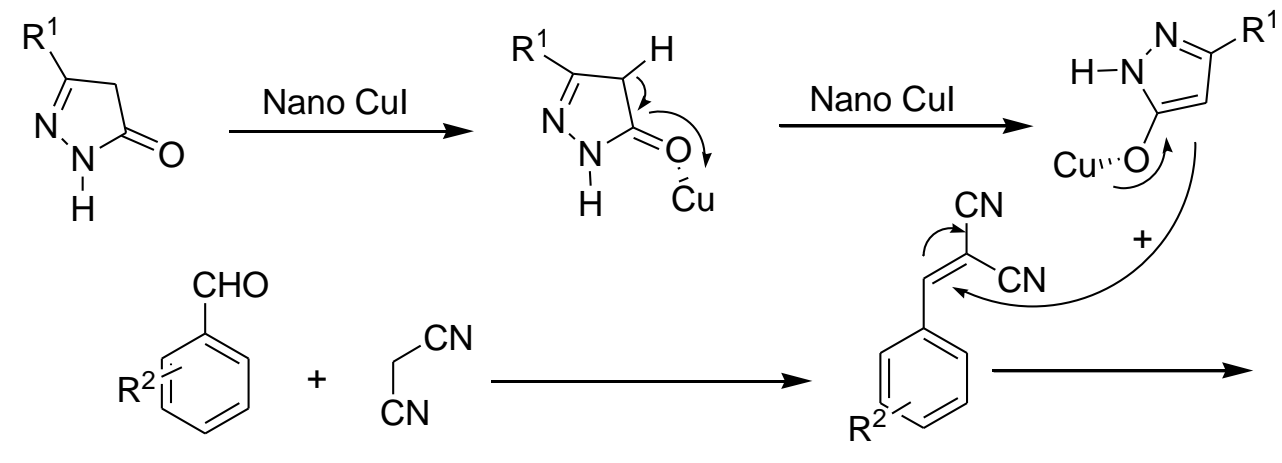

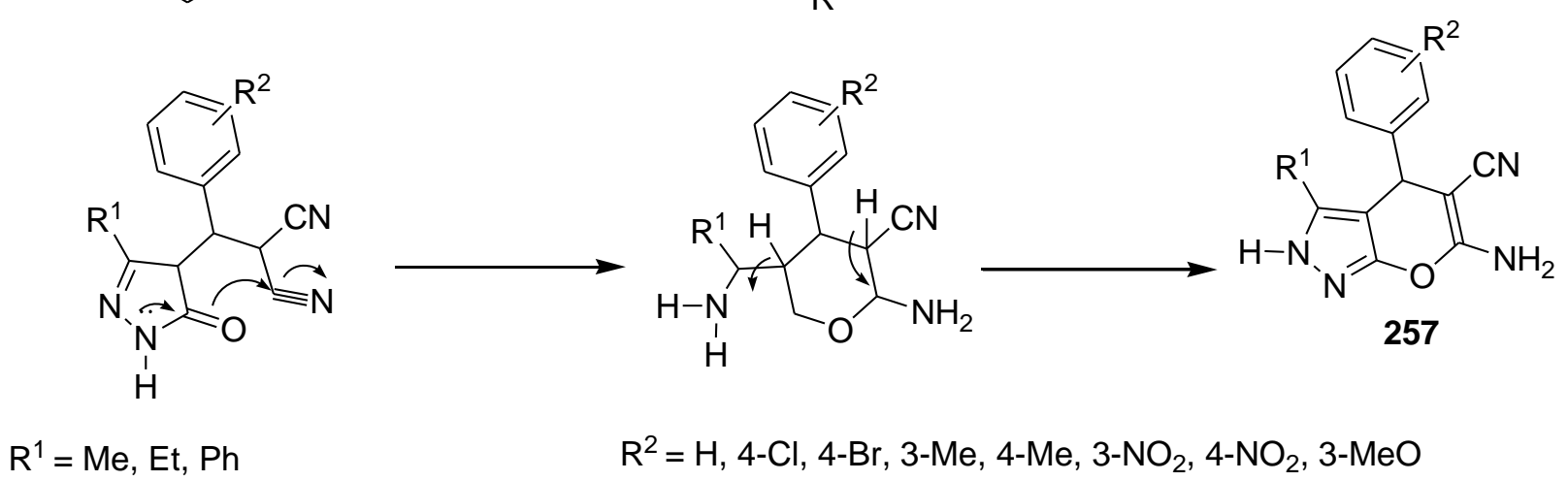

Scheme 82. Mechanism.

\section{Biological Activities}

Pyranopyrazoles in general are biologically active and have remarkable antimicrobial ${ }^{53,58}$, anticancer, ${ }^{43}$ antiinflammatory, ${ }^{23,53,112}$ analgesic, anticonvulsant, anti-platelet, vasodilator, ${ }^{3}$ antifungal, ${ }^{24,42,97}$ potential Chk1 inhibitors, $^{113,114}$ herbicidal $^{16}$ and molluscicidal properties. ${ }^{33,34}$ Moreover, pyranopyrazoles were found to be effective inhibitors to steel corrosion ${ }^{6}$ and as antioxidants for lubricant oil. ${ }^{5}$

Since these MCRs can lead to a variety of pyrano[2,3-c]pyrazoles by virtue of aryl and hetaryl aldehydes, hydrazines and malononitriles and other reactants, the researchers from time to time have subjected the novel synthesized compounds to diverse type of biological activities which may be summed up in the following:

Tetrahydroquinolines derivatives being biological active anti-HIV, antibacterial, antifungal, antimalarial, antitrypanosomal, antitumor, psychotropic, anti-allergic, anti-inflammatory, and estrogenic agents, were incorporated with pyranopyrazoles to obtain potential biologically active compounds 21-23. ${ }^{15}$

Tacconi and co-workers prepared pyranopyrazoles $\mathbf{2 5}$ and screened for fungicidal, herbicidal and insecticidal activities.

Ismail and co-workers prepared benzamide based pyranopyrazoles $\mathbf{3 7}$ and screened for their anti-inflammatory and ulcerogenic activities. All compounds were found to be active but, compound $\mathbf{2 6 3}$ showed excellent anti-inflammatory and good prostaglandin inhibitory activity ${ }^{23}$ (Figure 18). 
<smiles>Cc1nn(C)c2c1C(Br)C(C(N)=O)=C(N)O2</smiles>

antibacterial and antifungal

$\mathrm{Ar}=4-\mathrm{Cl}-\mathrm{Ph}, 3,4-$ dimethoxy $-\mathrm{Ph}$, 2,3,4-trimethoxy--Ph, 3-HO-4-MeO$\mathrm{Ph}, 1 \mathrm{H}$-indol-3-yl, 4-HO-3-MeO-Ph 2-Cl-6-Me-quinolin-3-yl<smiles>[R7]Nc1ncnc2c1C([R])c1c(C)n[nH]c1O2</smiles>

anti-inflammatory agent $\mathrm{R}^{1}=3$,4-dichloro- $\mathrm{Ph}$, naphthyl, thienyl $\mathrm{R}^{2}=\mathrm{H}, \mathrm{Me}$<smiles>Cc1nn(-c2ccc([N+](=O)[O-])cc2)c2c1C(C)(C)C(C#N)=C(N)O2</smiles>

261

herbicidal agent<smiles>[R]C1=C(C#N)C(Br)c2c([R])nn([R20])c2O1</smiles>

potential Chk1 inhibitors $\mathrm{R}^{1}=\mathrm{H}, \mathrm{Ph}$

$\mathrm{R}^{2}=\mathrm{Me}, 1$-methylmidazole

$\mathrm{R}^{3}=\mathrm{NH}_{2},{ }^{+} \mathrm{NH}_{3}$

$\mathrm{Ar}=$ 4-MeO-Ph, 3,4-dihydroxy-Ph,

3,4-dimethoxy- $\mathrm{Ph}$, 2-pyridinyl, $\mathrm{C}_{5} \mathrm{H}_{8} \mathrm{~N}-\mathrm{Me}$
$\mathrm{R}=\mathrm{H}, \mathrm{Ph}$

262

antibacterial

\section{Figure 17}<smiles>COc1ccc(OC)c(C2C(C#N)=C(N)Oc3c2c(C)nn3C(=O)COc2ccccc2C(N)=O)c1</smiles>

263

\section{Figure 18}

Some indole based pyranopyrazoles 39 were found to be active antibacterial, antifungal and anti-oxidant agents. $^{24}$

4-Hetaryl pyranopyrazoles 15 exhibited moderate molluscicidal activity against Biomphalaria alexandrina snails. ${ }^{33,34}$ while other deivatives of $\mathbf{1 5}$ showed antibacterial, antifungal, anti-inflammatory and anticancer activity against liver carcinoma cells. ${ }^{38,64,43}$

Compounds 110-113 were found active antibacterial. Moreover, derivatives containing halo group at $2^{\text {nd }}$ position of substituent exhibited both antibacterial and antifungal activities. ${ }^{46}$ 
Pyranopyrazoles 123 showed biological, anti-inflammatory, analgesic, anticonvulsant activities and were found potential antimicrobial agent. It was observed that presence of halo atoms increased biological action. ${ }^{53}$

Pyranopyrazoles $\mathbf{1 3 6}$ were tested for antibacterial activity against eight human pathogens and some were found active more than the standard drugs. ${ }^{55}$

Spiropyrano[2,3-c]pyrazoles 152 exhibited moderate antimicrobial activity against Escherichia coli and staphylococcus aureus. ${ }^{58}$

Derivatives of compounds $\mathbf{2 8}$ showed moderate inhibition effect on bacteria. ${ }^{59}$

Various derivatives of pyranopyrazoles 175-177 showed antibacterial, anti-inflammatory and cytotoxicity. ${ }^{64}$

Pyrano[2,3-c]pyrazoles 192, 193 exhibited moderate antibacterial activity. ${ }^{68}$

Synthesized compounds 157, 221 showed good antibacterial activity. ${ }^{100}$

Compounds $\mathbf{2 3 9}$ were tested for in vitro antioxidant and antimicrobial activities and found active agents. ${ }^{105}$

\section{Conclusions}

This review summarizes the synthesis of pyrano[2,3-c]pyrazoles which, either have a hydrogen atom at 4position or condensed spiro group. Synthesis focuses on two component or multi-component reactions including three, four and/or five reactants. Reactions conditions are variable including green approach, nanoparticulates, heteropolyacid, reflux temperature, room temperature, organic catalyst, microwave and ultrasonic irradiations. Most common reagents for synthesis are pyrazolone, benzylide, hydrazine, $\beta$ ketoesters, malononitrile, aldehydes and ketones. Various substituted phenyl, polynuclear naphthalene, anthracene as well as number of heterocyclic moiety such as furan, thiophene, indole, tetrahydroquinoline have been incorporated at 4-position. Most of the pyrano[2,3-c]pyrazoles have amino and cyano groups at sixth and fifth position respectively, but some shows variations and have hydrogen, aryl or other group. Compounds are reported as antibacterial, antifungal, anti-oxidant, anti-inflammatory, anti-ulcerogenic, antianalgesic, anticonvulsant and insecticidal agents. X-Ray studies done to confirm the structure and position of hydrogen atom in the pyrazolone ring.

\section{References}

1. Myrboh, B.; Mecadon, H.; Rohman, M.; Rajbangshi, M.; Kharkongor, I.; Laloo, B.; Kharbangar, I.; and Kshiar. B. Org. Prep. Proc. Int. 2013, 45, 253-303.

https://doi.org/10.1080/00304948.2013.798566

2. Fadda, A.; El-Mekabaty, A.; Elattar, K. Synth. Commun. 2013, 43, 2685-2719.

https://doi.org/10.1080/00397911.2012.744842

3. Das, D.; Banerjee, R.; Mitra, A. J. Chem. Pharm. Res. 2014, 6, 108-116.

4. Al-Amiery, A.; Al-Bayati, R.; Saed, F.; Ali, W.; Kadhum, A.; Mohamad, A. Molecules 2012, 17, 1037710389. https://doi.org/10.3390/molecules170910377

5. Ahmad, M. R.; Mohammed, A. A. K.; Ali, Y.; Al-Messri, Z. A. K. Iraqi J. Sci. 2014, 55, 1-11.

6. Yadav D. K.; Quraishi, M. A. Ind. Eng. Chem. Res. 2012, 51, 8194-8210. 
7. Stollé, R. Ber. Dtsch. Chem. Ges. 1905, 38, 3023-3032.

https://doi.org/10.1002/cber.190503803111

8. Wolff, L. Ber. Dtsch. Chem. Ges. 1905, 38, 3036-3041.

https://doi.org/10.1002/cber.190503803113

9. Junek H.; Aigner, H. Chem. Ber. 1973, 106, 914-921.

https://doi.org/10.1002/cber.19731060323

10. Khan, M. A.; Cosenza, A. G.; Ellis, G. P. J. Heterocycl. Chem. 1982, 19, 1077-1085.

https://doi.org/10.1002/jhet.5570190520

11. Khan, M. A.; Ellis, G. P.; Pagotto, M. C. J. Heterocycl. Chem. 2001, 38, 193-197.

https://doi.org/10.1002/ihet.5570380129

12. Otto, H. H. Arch. Pharm. 1974, 307, 444-447.

https://doi.org/10.1002/ardp.19743070609

13. Wang, J.; Huang, G.-B.; Yang, L.-J.; Li, F.; Nie, J.; Maa, J.-A. J. Fluorine Chem. 2015, 171, 27-35. https://doi.org/10.1016/j.jfluchem.2014.10.008

14. Katritzky, A.; Rachwal, S.; Rachwal, B. Tetrahedron 1996, 52, 15031-15070.

https://doi.org/10.1016/S0040-4020(96)00911-8

15. Pandit R. P.; Lee, Y. R. Mol. Diversit. 2014, 18, 39-50.

https://doi.org/10.1007/s11030-013-9482-6

16. Tacconi, G.; Gatti, G.; Desimoni, G.; Messori, V. J. Prakt. Chem. 1980, 322, 831-834.

https://doi.org/10.1002/prac.19803220519

17. Gogoi S.; Zhao, C.-G. Tetrahedron Lett. 2009, 50, 2252-2255.

https://doi.org/10.1016/i.tetlet.2009.02.210

18. Elziaty, A. K.; Mostafa, O. E. A.; El-Bordany, E. A.; Nabil, M.; Madkour, H. M. F. Int. J. Sci. \& Eng. Res. 2014, 5, 727-735.

19. Smith, R. Anal. Bioanal. Chem. 2006, 385, 419-421.

https://doi.org/10.1007/s00216-006-0437-y

20. Peng, Y.; Song, G.; Dou, R. Green Chem. 2006, 8, 573-575.

https://doi.org/10.1039/b601209d

21. Trichili, S.; Kammoun, M.; Abid, S.; Ammar, H. Synth. Commun. 2014, 44, 2808-2817.

https://doi.org/10.1080/00397911.2014.903422

22. Shestopalov, A. M.; Yakubov, A. P.; Tsyganov, D. V.; Emel'yanova, Y. M.; Nesterov, V. N. Chem. Heterocycl. Compd. 2002, 38, 1180-1189.

https://doi.org/10.1023/A:1021773228201

23. Ismail, M. M. F.; Khalifa, N. M.; Fahmy, H. H.; Nossier, E. S.; Abdulla, M. M. J. Heterocycl. Chem. 2014, $51,450-458$.

https://doi.org/10.1002/jhet.1757

24. Saundane, A. R.; Walmik, P.; Yarlakatti, M.; Katkar, V.; Verma, V. A. J. Heterocycl. Chem. 2014, 51, 303314.

https://doi.org/10.1002/jhet.1582

25. Dyachenko V. D.; Rusanov, E. B. Chem. Heterocycl. Compd. 2004, 40, 231-240.

https://doi.org/10.1023/B:COHC.0000027898.06493.c5

26. Hafez, E. A. A.; Galil, F. M. A.; Sherif, S. M.; Elnagdi, M. H. J. Heterocycl. Chem. 1986, 23, 1375-1378. https://doi.org/10.1002/ihet.5570230523

27. Al-Thebeiti M. S.; El-Zohry, M. F. Heteroat. Chem. 1995, 6, 567-574. 
https://doi.org/10.1002/hc.520060612

28. Parmar, N. J.; Teraiya, S. B.; Patel, R. A.; Talpada, N. P. Tetrahedron Lett. 2011, 52, 2853-2856. https://doi.org/10.1016/i.tetlet.2011.03.108

29. Elgemeie, G. E. H.; Riad, B. Y.; Nawwar, G. A.; Elgamal, S. Arch. Pharm. Chem. Life Sci. 1987, 320, 223228.

https://doi.org/10.1002/ardp.19873200307

30. Abdou, S.; Fahmy, S. M.; Sadek, K. U.; Elnagdi, M. H. Heterocycles 1981, 16, 2177-2180. https://doi.org/10.3987/R-1981-12-2177

31. Pasternak, P. V.; Averkiev, B. B.; Antipin, M. Y.; Peregudov, A. S.; Chkanikov, N. D. J. Fluorine Chem. 2004, 125, 1853-1868.

https://doi.org/10.1016/i.jfluchem.2004.06.008

32. Golubev, A. S.; Pasternak, P. V.; Shidlovskii, A. F.; Savelèva, L. N.; Averkiev, B. B.; Nesterov, V. N.; Antipin, M. Y.; Peregudov, A. S.; Chkanikov, N. D. J. Fluorine Chem. 2002, 114, 63-74.

https://doi.org/10.1016/S0022-1139(01)00559-0

33. Abdelrazek, F. M.; Metz, P.; Metwally, N. H.; El-Mahrouky, S. F. Arch. Pharm. Chem. Life Sci. 2006, 339, 456-460.

https://doi.org/10.1002/ardp.200600057

34. Abdelrazek, F. M.; Metz, P.; Kataeva, O.; Jager, A.; El-Mahrouky, S. F. Arch. Pharm. Chem. Life Sci. 2007, 340, 543-548.

https://doi.org/10.1002/ardp.200700157

35. Maruoka, H.; Masumoto, E.; Eishima, T.; Okabe, F.; Nishida, S.; Yoshimura, Y.; Fujioka, T.; Yamagata, K. J. Heterocycl. Chem. 2009, 46, 782-787.

https://doi.org/10.1002/jhet.117

36. Jin, T.-S.; Zhao, R.-Q.; Li, T.-S. Arkivoc 2006, 176-182.

http://dx.doi.org/10.3998/ark.5550190.0007.b18

37. Jin, T.-S.; Wang, A.-Q.; Cheng, Z.-L.; Zhang, J.-S.; Li, T. S. Synth. Commun. 2005, 35, 137-143. https://doi.org/10.1081/SCC-200046527

38. Prajapati, S. P.; Patel, D. P.; Patel, P. S. J. Chem. Pharm. Res. 2012, 4, 2652-2655.

39. Yu, C.; Yao, C.; Li, T.; Wang, X. Res. Chem. Intermed. 2014, 40, 1537-1544.

https://doi.org/10.1007/s11164-013-1058-7

40. Bhavanarushi, S.; Kanakaiah, V.; Yakaiah, E.; Saddanapu, V.; Addlagatta, A.; Rani, J. V. Med. Chem. Res. 2013, 22, 2446-2454.

https://doi.org/10.1007/s00044-012-0239-z

41. Zhou, J.-F.; Tu, S.-J.; Zhu, H.-Q.; Zhi, S.-J. Synth. Commun. 2002, 32, 3363-3366. https://doi.org/10.1081/SCC-120014044

42. Katariya L. K.; Kharadi, G. J. International Journal for Pharmaceutical Research Scholars 2014, 3, 627637.

43. Mohamed, N. R.; Khaireldin, N. Y.; Fahmy, A. F.; El-Sayed, A. A. Der Pharma Chemica. 2010, 2, 400-417.

44. Guo, S.-B.; Wang S.-X.; Li, J. T. Synth. Commun. 2007, 37, 2111-2120. https://doi.org/10.1080/00397910701396906

45. Kamble, R. D.; Dawane, B. S.; Yemul, O. S.; Kale, A. B.; Patil, S. D. Res. Chem. Intermed. 2012, 39, 38593866.

https://doi.org/10.1007/s11164-012-0887-0

46. Dawane, B. S.; Yemul, O. S.; Chobe, S. S.; Mandawad, G. G.; Kamble, R. D.; Shinde, A. V.; Kale, V. S.; 
Hurne, A. O.; Pawde, M. A.; Kale, M. P.; Desai, N. P.; Salgare, R. R.; Patil, M. B.; Mundhe, S. N.; Chavan, S. R. Der Pharma Chemica. 2011, 3, 300-305.

47. Eskandari, K.; Karami, B.; Khodabakhshi, S. Catal. Commun. 2014, 54, 124-130. https://doi.org/10.1016/i.catcom.2014.05.029

48. Xu, J.; Liu, B.; Wu, W.; Qain, C.; Wu, Q.; Lin, X. J. Org. Chem. 2006, 71, 3991-3993. https://doi.org/10.1021/jo0600914

49. Ranu B.; Banerjee, S. Org. Lett. 2005, 7, 3049-3052.

https://doi.org/10.1021/ol051004h

50. Khurana J. M.; Chaudhary, A. Green Chem. Lett. Rev. 2012, 5, 633-638.

https://doi.org/10.1080/17518253.2012.691183

51. Niknam K.; Piran, A. Green Sustainable Chem. 2013, 3, 1-8.

https://doi.org/10.4236/gsc.2013.32A001

52. Heravi, M. M.; Ghods, A.; Derikvand, F.; Bakhtiari, K.; Bamoharram, F. F. J. Iran. Chem. Soc. 2010, 7, 615-620.

https://doi.org/10.1007/BF03246049

53. Mandour, A. H.; El-Sawy, E. R.; Ebaid, M. S.; Hassan, S. M. Acta Pharm. 2012, 62, 15-30. https://doi.org/10.2478/v10007-012-0007-0

54. Rodinovskaya, L. A.; Gromova, A. V.; Shestopalov, A. M.; Nesterov, V. N. Russ. Chem. Bull. 2003, 52, 2207-2213.

https://doi.org/10.1023/B:RUCB.0000011880.05561.c1

55. Kathrotiya, H. G.; Patel, R. G.; Patel, M. P. J. Serb. Chem. Soc. 2012, 77, 983-991. https://doi.org/10.2298/JSC110805199K

56. Enders, D.; Grossmann, A.; Gieraths, B.; Duzdemir, M.; Merkens, C. Org. Lett. 2012, 14, 4254-4257. https://doi.org/10.1021/ol301983f

57. Shestopalov, A. M.; Emeliyanova, Y. M.; Shestopalov, A. A.; Rodinovskaya, L. A.; Niazimbetova, Z. I.; Evans, D. H. Tetrahedron 2003, 59, 7491-7496.

https://doi.org/10.1016/S0040-4020(03)01178-5

58. Al-Thebeiti, M. S. Heterocycles 2000, 53, 621-628.

https://doi.org/10.3987/COM-99-8797

59. Riad, B. Y.; Abdelhamid, A. O.; Khalifa, F. A.; Saleh, Y. E. Arch. Pharmacal Res. 1989, 12, 201-206. https://doi.org/10.1007/BF02855555

60. Redkin, G. R.; Shemchuk, L. A.; Chernykh, V. P.; Shishkin, O. V.; Shishkina, S. V. Tetrahedron 2007, 63, 11444-11450.

https://doi.org/10.1016/i.tet.2007.08.050

61. Dandia, A.; Arya, K.; Sati, M.; Sharma, R. Heterocycl. Commun. 2003, 9, 415-420. https://doi.org/10.1515/HC.2003.9.4.415

62. Poomathi, N.; Kamalraja, J.; Mayakrishnan, S.; Muralidharan, D.; Perumal, P. T. Synlett 2014, 25, 708712.

https://doi.org/10.1055/s-0033-1340666

63. Shanthi, G.; Subbulakshmi, G.; Perumal, P. S. Tetrahedron 2007, 63, 2057-2063.

https://doi.org/10.1016/j.tet.2006.12.042

64. Mandha, S. R.; Siliveri, S.; Alla, M.; Bommena, V. R.; Bommineni, M. R.; Balasubramanian, S. Bioorg. Med. Chem. Lett. 2012, 22, 5272-5278.

https://doi.org/10.1016/i.bmcl.2012.06.055 
65. Elinson, M. N.; Dorofeev, A. S.; Miloserdov, F. M.; Nikishin, G. I. Mol. Diver. 2009, 13, 47-52. https://doi.org/10.1007/s11030-008-9100-1

66. Litvinov Y. M.; Shestopalov, A. M. Russ. Chem. Bull. 2008, 57, 2223-2226. https://doi.org/10.1007/s11172-008-0308-0

67. Litvinov, Y. M.; Mortikov, V. Y.; Shestopalov, A. M. J. Comb. Chem. 2008, 10, 741-745. https://doi.org/10.1021/cc800093q

68. Kassem, E. M.; El-Sawy, E. R.; Abd-Alla, H. I.; Mandour, A. H.; Abdel-Mogeed, D.; El-Safty, M. M. Egypt. Pharmaceut. J. 2012, 11, 116-123.

69. Zolfigol, M. A.; Tavasoli, M.; Moosavi-Zare, A. R.; Moosavi, P.; Kruger, H. G.; Shiri, M.; Khakyzadeh, V. RSC Adv. 2013, 3, 25681-25685.

https://doi.org/10.1039/c3ra45289a

70. Siddekha, A.; Nizam, A.; Pasha, M. A. Spectrochim. Acta Part A 2011, 81, 431-440. https://doi.org/10.1016/j.saa.2011.06.033

71. Kiyani, H.; Samimi, H. A.; Ghorbani, F.; Esmaieli, S. Current Chemistry Letters 2013, 2, 197-206. https://doi.org/10.5267/i.ccl.2013.07.002

72. Vasuki G.; Kumaravel, K. Tetrahedron Lett. 2008, 49, 5636-5638. https://doi.org/10.1016/i.tetlet.2008.07.055

73. Pawar, P. B.; Jadhav, S. D.; Patil, B. M.; Shejwal, R. V.; Patil, S. Arch. Appl. Sci. Res. 2014, 6, $150-158$.

74. Reddy M. B. M.; Pasha, M. A. Indian J. Chem., Sect. B. 2012, 51, 537-541.

75. Reddy, M. B. M.; Jayashankara, V. P.; Pasha, M. A. Synth. Commun., 2010, 40, 2930-2934. https://doi.org/10.1080/00397910903340686

76. Wu, M.; Feng, Q.; Wan, D.; Ma, J. Synth. Commun. 2013, 43, 1721-1726. https://doi.org/10.1080/00397911.2012.666315

77. Kanagaraj K.; Pitchumani, K. Tetrahedron Lett. 2010, 51, 3312-3316. https://doi.org/10.1016/i.tetlet.2010.04.087

78. Darandale, S. N.; Sangshetti, J. N.; Shinde, D. B. J. Korean Chem. Soc. 2012, 56, 328-33. https://doi.org/10.5012/jkcs.2012.56.3.328

79. Mecadon, H.; Rohman, M. R.; Rajbangshi, M.; Myrboh, B. Tetrahedron Lett. 2011, 52, 2523-2525. https://doi.org/10.1016/j.tetlet.2011.03.036

80. Reddy, G. M.; Garcia, J. R. J. Heterocycl. Chem. 2017, 54, 89-94. https://doi.org/10.1002/ihet.2544

81. Imène, A. M.; Wassima, G.; Raouf, B.; Taous, B.; Abdelmadjid, D. Der Pharma Chemica 2015, 7, 175180.

82. Kumar, G. S.; Kurumurthy, C.; Veeraswamy, B.; Rao, P. S.; Rao, P. S.; Narsaiah, B. Org. Prep. Proced. Int. 2013, 45, 429-436.

https://doi.org/10.1080/00304948.2013.816220

83. Nagarajan A.; Reddy, B. Synlett 2009, 12, 2002-2004.

84. Moeinpour F.; Khojastehnezhad, A. Arabian J. Chem. 2017, 10, S3468-S3474. https://doi.org/10.1016/i.arabjc.2014.02.009

85. Babaie M.; Sheibani, H. Arabian J. Chem., 2011, 4, 159-162. https://doi.org/10.1016/j.arabjc.2010.06.032

86. El-Remaily, M. A. E. A. A. Tetrahedron 2014, 70, 2971-2975. https://doi.org/10.1016/i.tet.2014.03.024

87. Saha, A.; Payra, S.; Banerjee, S. Green Chem. 2015, 17, 2859-2866. 
https://doi.org/10.1039/C4GC02420F

88. Borhade A. V.; Uphade, B. K. J. Iran Chem. Soc. 2015, 12, 1107-1113.

https://doi.org/10.1007/s13738-014-0571-y

89. Ebrahimipour, S. Y.; Ranjabr, Z. R.; Kermani, E. T.; Amiri, B. P.; Rudbari H. A.; Sacca, A.; Hoseinzade, F. Transition Met. Chem. 2015, 40, 39-45.

https://doi.org/10.1007/s11243-014-9887-9

90. Shinde, P. V.; Gujar, J. B.; Shingate, B. B.; Shingare, M. S. Bull. Korean Chem. Soc. 2012, 33, 1345-1348. https://doi.org/10.5012/bkcs.2012.33.4.1345

91. Nimbalkar, U. D.; Seijas, J. A.; Vazquez-Tato, M. p.; Damale, M. G.; Sangshetti, J. N.; Nikalje, A. P. G.; Molecules, 2017, 22, doi: 10.3390/molecules22101628.

https://doi.org/10.3390/molecules22101628

92. Khurana, J. M.; Nand, B.; Kumar, S. Synth. Commun. 2011, 41, 405-410. https://doi.org/10.1080/00397910903576669

93. Chavan, H. V.; Babar, S. B.; Hoval, R. U; Bandgar, B. P. Bull. Korean Chem. Soc. 2011, 32, 3963-3966. https://doi.org/10.5012/bkcs.2011.32.11.3963

94. Swaroop, T. R.; Kumar, K. S. S.; Palanivelu, M.; Chaitanya, S.; Rangappa, K. S. J. Heterocycl. Chem. 2014, 51, 1866-1870.

https://doi.org/10.1002/jhet.1864

95. Ebrahimi, J.; Mohammadi, A.; Pakjoo, V.; Bahramzade, E.; Habibi, A. J. Chem. Sci. 2012, 124, $1013-1017$. https://doi.org/10.1007/s12039-012-0310-9

96. Devkate, C. G.; Warad, K. D.; Gaikwad, D. D.; Siddique, M. M. Current Global Reviewer 2015, 1, 96-101.

97. Amin, B. N.; Parikh, A. R.; Parikh, H.; Gudaparthi, V. Sch. Acad. J. Pharm. 2014, 3, 208-212.

98. Brahmachari G.; Banerjee, B. ACS Sustainable Chem. Eng. 2014, 2, 411-422.

https://doi.org/10.1021/sc400312n

99. Litvinov, Y. M.; Shestopalov, A. A.; Rodinovskaya, L. A.; Shestopalov, A. M. J. Comb. Chem. 2009, 11, 914-919.

https://doi.org/10.1021/cc900076j

100. Ahadi, S.; Yasaei, Z.; Bazgir, A. J. Heterocycl. Chem. 2010, 47, 1090-1094.

https://doi.org/10.1002/jhet.437

101. Koohshari, M.; Dabiri, M.; Salehi, P. RSC Adv. 2014, 4, 10669-10671.

https://doi.org/10.1039/c3ra47639a

102. Pore, D. M.; Patil, P. B.; Gaikwad, D. S.; Hegade, P. G.; Patil, J. D.; Undale, K. A. Tetrahedron Lett. 2013, 54, 5876-5878.

https://doi.org/10.1016/j.tetlet.2013.08.084

103. Wang, C.; Jiang, Y.; Yan, C. Chin. Chem. Lett. 2015, 26, 889-893.

https://doi.org/10.1016/j.cclet.2015.05.018

104. Guo, R.-Y.; An, Z.-M.; Mo, L.-P.; Yang, S.-T.; Liu, H.-X.; Wang, S.-X.; Zhang, Z.-H. Tetrahedron 2013, 69, 9931-9938.

https://doi.org/10.1016/j.tet.2013.09.082

105. Ambethkar, S.; Padmini, V.; Bhuvanesh, N. J. Adv. Res. 2015, 6, 975-985.

https://doi.org/10.1016/j.jare.2014.11.011

106. Zonouz, A. M.; Eskandari, I.; Khavasi, H. R. Tetrahedron Lett. 2012, 53, 5519-5522.

https://doi.org/10.1016/j.tetlet.2012.08.010

107. Al-Matar, H. M.; Khalil, K. D.; Adam, A. Y.; Elnagdi, M. H. Molecules 2010, 15, 6619-6629. 


\section{https://doi.org/10.3390/molecules15096619}

108. Jayabal K.; Paramasivan, T. P. Tetrahedron Lett. 2014, 55, 2010-2014.

https://doi.org/10.1016/j.tetlet.2014.02.019

109. Alizadeh A.; Bayat, F. Helv. Chim. Acta. 2014, 97, 694-700.

https://doi.org/10.1002/hlca.201300260

110. Lu, Z.; Xiao, J.; Wang, D.; Li, Y. Asian J. Org. Chem. 2015, 4, 487-492.

https://doi.org/10.1002/ajoc.201500039

111. Safaei-Ghomi, J.; Ziarati, A.; Tamimi, M. Acta Chim. Slov. 2013, 60, 403-410.

112. Zaki, M. E. A.; Soliman, H. A.; Hiekal, O. A.; Rashad, A. E. Z. Naturforsch., C: Biosci. 2006, 61, 1-5. https://doi.org/10.1515/znc-2006-1-201

113. Foloppe, N.; Fisher, L. M.; Howes, R.; Potter, A.; Robertson, A. G. S.; Surgenor, A. E. Bioorg. Med. Chem. 2006, 14, 4792-4802.

https://doi.org/10.1016/j.bmc.2006.03.021

114. Ramtekkar, R.; Kumarvel, K.; Vasuki, G.; Sekar, K.; Krishna, R. Lett. Drug Des. Discov. 2009, 6, 579-584. https://doi.org/10.2174/157018009789353455

\section{Authors' Biographies}

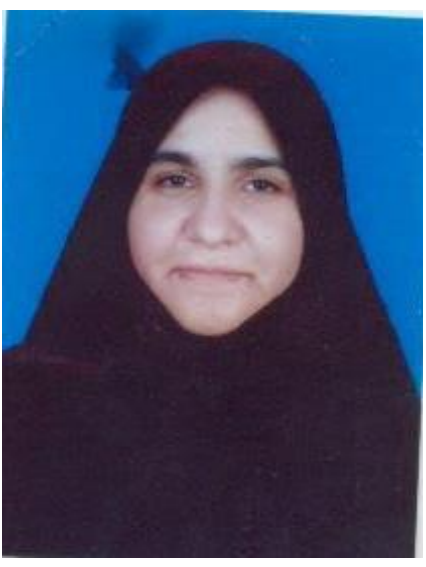

Noreen Aslam was born in Bahawalpur (Punjab) Pakistan and obtained her B.Sc. and M.Sc. degree from The Islamia University of Bahawalpur, Pakistan in 2002 \& 2005 respectively. She enrolled for MPhil in Department of Chemistry, The Islamia University of Bahawalpur and completed degree in 2007. She joined a private school \& college system and after few years of teaching enrolled in PhD under indigenous fellowship program of Higer education commission Pakistan. She availed IRSIP to work as visiting researcher in Bio-21 Institute of Melbourne University, Australia and got a PhD degree in 2017. She is currently working as visiting demonstrator of Chemistry in Govt. Sadiq College Women University Bahawalpur Pakistan. Her research interests include synthesis of heterocyclic compounds, derivatization and multistep synthesis of small molecules. She has so far authored eight research papers 


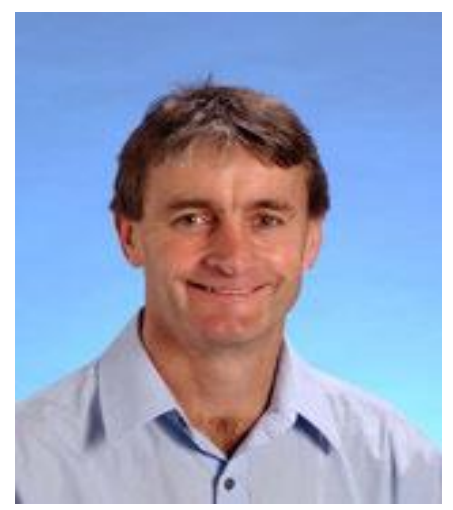

Jonathan Michael White was born in Murapara, New Zealand. He did his BSc(Hons) in 1982 and PhD (Organic chemistry) from University of Canterbury in 1985. He got postdoctoral fellowship from Bristol University and then from Australian National University. He has occupied teaching and research positions in various universities such as University of Canterbury, Northwestern Univesity, Bristol University, Australian National University, and University of Melbourne. Since 1982 he has authored more than 268 articles in peer-reviewed journals and chapters in four books. He holds editorial position for many journals such as Organic Chemistry International, Organic Letters (ACS Journal), Australian Journal of Chemistry, Arkivoc and Acta Crystallographica Section C. He is reviewer of many renowed journals such as Journal of Organic Chemistry, Journal of the American Chemical Society, Synlett, Journal of Organometallic Chemistry, Acta Crystallographica, Accounts of Chemical Research, The Australian Journal of Chemistry, Science. He has supervised $18 \mathrm{PhD}$ and more than 70 undergraduate scholars. Since 1992 he has received many research grants from both government and private sector and also has patents in radioprotector field. He is active member of many communities and societies.

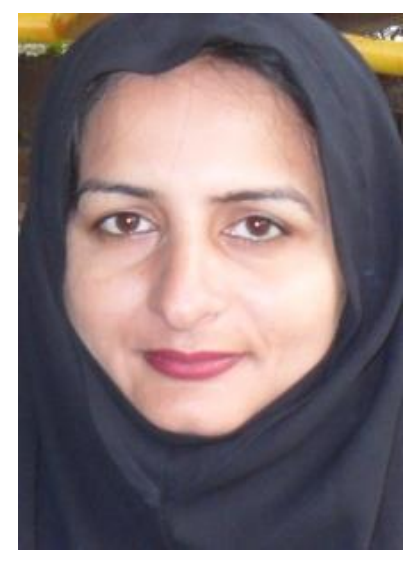

Ansa Madeeha Zafar was born in Hasilpur (Bahawalpur), Pakistan. She obtained her B.Sc. and M.Sc. degree from The Islamia University of Bahawalpur Pakistan in 2003 and 2006 respectively. She joined the MPhil and then PhD program of the department of Chemistry, The Islamia University of Bahawalpur, Pakistan in 2008, under indigenous fellowship of Higer education commission, Pakistan. She was awarded Ph. D. degree in 2015. She is currently working as an Assistant Professor of Chemistry in Govt. Sadiq College Women University Bahawalpur Pakistan. Her research focuses on the heterocyclic synthesis and green chemistry. She has so far four publications. She is member of chemical society of Pakistan 


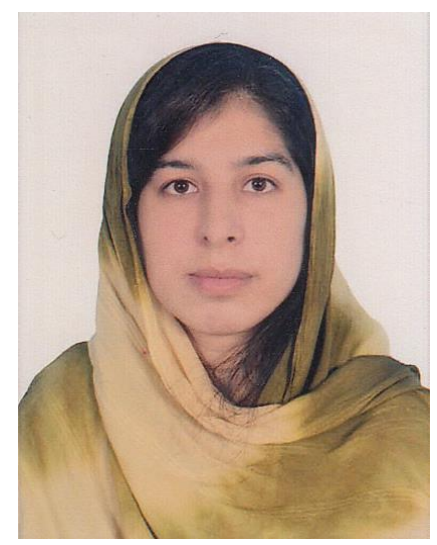

Mussarat Jabeen was born in Bahawalpur (Punjab), Pakistan. She obtained her M.Sc. and Mphil degrees from The Islamia University of Bahawalpur, Pakistan in 2007 and 2011 respectively. She was enrolled for her PhD degree in Department of Chemistry, The Islamia University of Bahawalpur, Pakistan and awarded PhD degree in 2017. She is working as visiting lecturer in Department of Chemistry, The Govt. Sadiq College Women University, Bahawalpur. Her research interests include synthesis of heterocyclic compounds, azo dyes, Hydrazones and their metal complexes. She has so far authored seven research papers.

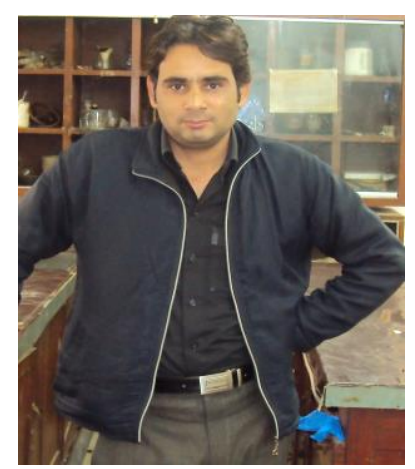

Abdul Ghafoor was born in Burewala, Pakistan in 1981. He was enrolled for PhD in Department of Chemistry, The Islamia University of Bahawalpur, Pakistan and received degree in 2016 under supervision of prof. Emeritus Dr. Misbahul Ain Khan. Since 2013, he started career as research assistant in Lahore University of Management Sciences and then moved to Cardiff University after availing IRSIP fellowship. He joined Unversity of Sahiwal in 2015 as visiting lecturer and now working as assistant professor in University of central Punjab and visiting teacher in Government College University Faisalabd. His research interests include synthesis and biological evaluation of heterocyclic compounds and so far published four research papers in international journals. 


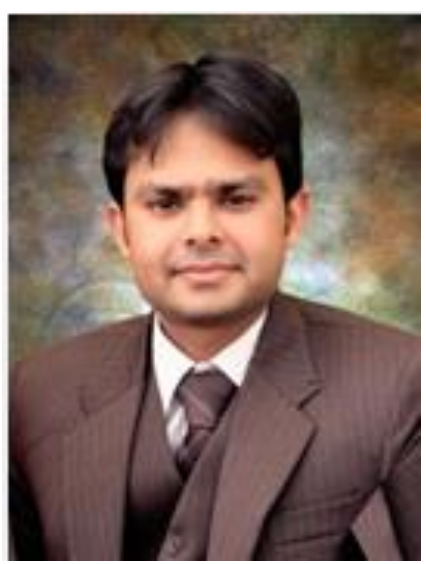

Naveed Sajid was born in Bahawalpur, Pakistan. He obtained his B.Sc. (Science) and M.Sc. (Organic Chemistry) degrees from The Islamia University of Bahawalpur, Pakistan, in 2003 and 2006 respectively. After working as Chemistry Lecturer at ARSH college in Bahawalpur, Pakistan from January 2006 to February 2007, he enrolled for MPhil and then for PhD degree in the Department of Chemistry, The Islamia University of Bahawalpur and graduated in 2018 under the supervision of Dr. Misbahul Ain Khan. During his PhD, he went to School of chemistry, Sydney University, Australia and worked on metal sensing probes. Since September 2017, he is working as a lecturer (visiting) in the Department of Chemistry, The Islamia University of Bahawalpur. His research interests include Heterocyclic synthesis, Dyes and Pigments and use of heterocyclic compounds in analytical chemistry. He has authored five research papers in peer-reviewed journals. He is a member of the International Union of pure and applied chemistry (IUPAC) and Chemical Society of Pakistan (CSP).

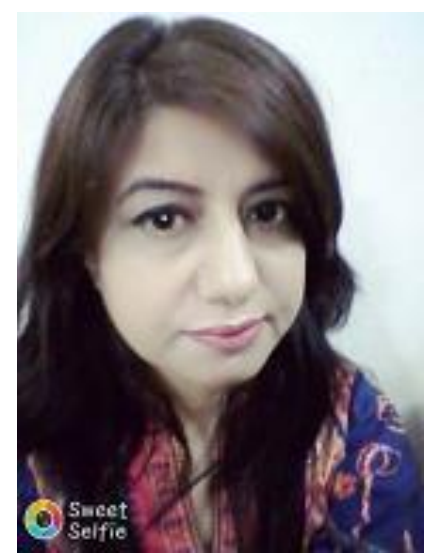

Shazia Noreen was born in Bahawalpur, Pakistan. She recieed her B.Sc., M.Sc., MPhil and PhD from the Islamia University of Bahawalpur in 1998, 2002, 2007, 2017, respectively. She has worked as visiting research scholar at Oxford University United Kingdom for six months. Her research focuses on the heterocyclic synthesis and green chemistry. She has so far four publications. She has worked as a Chemistry lecturer at The City School Bahawalpur for seven years and at Dominican Convent Higher Secondary School Bahawalpur for three years. She is Currently working as section head at Cantonment Board Public School and college Bahawalpur. 


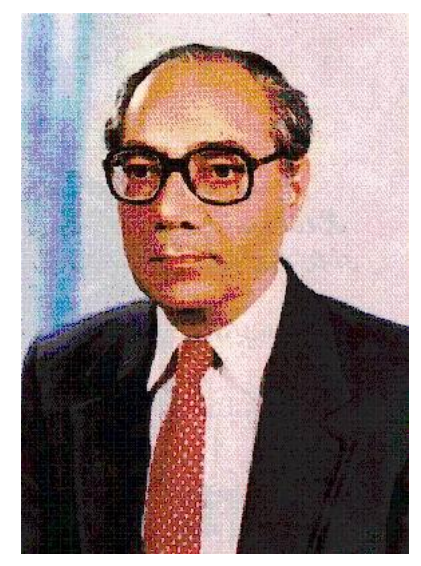

Misbahul Ain Khan was born on September 22, 1935. He obtained his B.Sc. and M.Sc. degrees from University of Karachi, Pakistan in 1957 and 1959 respectively. He joined the Memorial University of Newfoundland, Canada where he completed his M.Sc. in Organic Chemistry. He received his PhD degree from the University of Tasmania, Australia in 1968. Since then he has occupied teaching, research and administrative positions in various universities such as part-time Demonstrator in University of Tasmania, (1964-1967), Postdoctoral Research Fellow, St. Francis Xavier University, Canada, (1967-1970), Leverhulme Visiting Fellow, University of Wales, Institute of Science and Technology, Cardiff, UK, (1970-1971), Associate Professor, Instituto Militar de Engehharia, Rio de Janerio, Brazil, (1971-1975), Professor, Instituto Militar de Engehharia, Rio de Janerio, Brazil, (1975-1983), Visiting Scientist, St. Francis Xavier University, Canada, (1982-1983), Visiting Professor, Universidade Federal Fluminense, Rio de Janeiro, Brazil, (1997-1999). He joined as Professor \& Chairman in Department of Chemistry, Islamia University, Bahawalpur, Pakistan and retired as Vice-Chancellor (19841993). Then he worked as director General of Institute for the promotion of Science, Education \& Training, Ministry of Education, Islamabad (1993-1995) and Chairman of Pakistan Council of Scientific and Industrial Research (PCSIR) Pakistan (1999-2000). He is currently working as Professor Emeritus of Chemistry at the Islamia University of Bahawalpur, Pakistan. He has supervised twenty-four PhD and more than hundred sixty MS and MSc thesis, authored ninety-eight publications in peer-reviewed journals. He is a member of the American Chemical Society and Chemical Society of a Pakistan. He was the Joint Editor of Brazilian Chemical Journal "Anais de Associacao Brasileira de Quimica”, 1983 and Chief Editor, Managing Editor, Journal of Pure and Applied Sciences, Islamia University, Bahawalpur, Pakistan, (1984-1990). His research interests include the study, synthesis and reactivity of biologically important heterocycles and its applications in analytical chemistry. 